UNIVERSIDADE DE SÃO PAULO

FACULDADE DE EDUCAÇÃO

EDER MARQUES LOIOLA

UMA IDEIA DA AUTONOMIA DA ESCOLA

NA OBRA DE JOSÉ MÁRIO PIRES AZANHA

SÃO PAULO

2016 
EDER MARQUES LOIOLA

\section{UMA IDEIA DA AUTONOMIA DA ESCOLA NA OBRA DE JOSÉ MÁRIO PIRES AZANHA}

Dissertação apresentada à Faculdade de Educação da Universidade de São Paulo como parte dos requisitos para obtenção do título de Mestre em Educação

Área de concentração: Filosofia e Educação

Orientador: Prof. Dr. José Sérgio Fonseca de Carvalho

SÃO PAULO

2016 
AUTORIZO A REPRODUÇÃO E DIVULGAÇÃO TOTAL OU PARCIAL DESTE TRABALHO, POR QUALQUER MEIO CONVENCIONAL OU ELETRÔNICO, PARA FINS DE ESTUDO E PESQUISA, DESDE QUE CITADA A FONTE.

Catalogação na Publicação

Serviço de Biblioteca e Documentação

Faculdade de Educação da Universidade de São Paulo

$379.5 \quad$ Loiola, Eder Marques

L834i Uma ideia da autonomia da escola na obra de José Mário

Pires Azanha / Eder Marques Loiola; orientação José Sérgio

Fonseca de Carvalho. São Paulo: s. n., 2016.

$121 \mathrm{p}$.

Dissertação (Mestrado - Programa de Pós-Graduação em Educação. Área de Concentração: Filosofia e Educação) - Faculdade de Educação da Universidade de São Paulo.

1. Autonomia da escola 2. Democratização do ensino 3. Azanha, José Mário Pires I. Carvalho, José Sérgio Fonseca de, orient. 
Nome: LOIOLA, Eder Marques

Título: Uma ideia da autonomia da escola na obra de José Mário Pires Azanha

Dissertação apresentada à Faculdade de Educação da Universidade de São Paulo como parte dos requisitos para obtenção do título de Mestre em Educação.

Aprovado em:

Banca Examinadora

Prof. Dr.:

Instituição:

Julgamento:

Assinatura:

Prof. Dr.:

Instituição:

Julgamento:

Assinatura:

Prof. Dr.:

Instituição:

Julgamento:

Assinatura: 
Aos meus pais: a "Dona Dalva" e o "Jó". 


\section{AGRADECIMENTOS}

À minha mãe e aos meus irmãos pelo incentivo e apoio incondicional.

Ao prof ${ }^{\circ}$. José Sérgio, uma referência fundamental tanto em minha formação acadêmica quanto em meu percurso profissional. Graças a sua interpretação singular, não apenas conheci como aprendi a reconhecer o valor das obras de Arendt e Azanha. Em suma, devo-lhe muito mais do que as indicações esperadas de um orientador.

Aos amigos do Grupo de Pesquisa e Estudos sobre Educação e o Pensamento Contemporâneo (GEEPC), pela companhia, no forte sentido arendtiano, e pela discussão generosa de versões anteriores do texto.

Às professoras Maria Helena de Souza Patto e Cristiane Gottschalk, pela leitura atenta e pelas valiosas contribuições e críticas ao texto de qualificação do trabalho. À última devo também a fecunda aproximação com os escritos de Wittgenstein e dos autores analíticos. A dissertação certamente não tomaria esta forma sem suas aulas e sugestões.

Aos amigos da EMEF Prof ${ }^{\circ}$ João de Lima Paiva - em particular, Maria Antônia, Marcelo, Cidinha e Marlene - pelo apoio, companhia e por compartilharem a já lendária luta pela reformulação do projeto pedagógico da escola. Sou igualmente grato ao camarada Marcão, figura importante nos meus primeiros tempos de rede.

Aos poucos e valorosos amigos da graduação no Departamento de História: Daniel, Fernando, Juan e João. Sou especialmente grato ao Ariam, por ter me incentivado a pesquisar a obra do Azanha.

Ao grande amigo Jailtom, pelas conversas, cervejas, músicas e por, de maneira insuspeitada, me ensinar a desconfiar dos chavões políticos.

À Larissa e à "Malú" (in memoriam) pelo incondicional apoio, em diversos sentidos, e pela "estrutura" no começo da pesquisa e antes disso... A elas serei sempre grato.

À Secretaria de Educação do Município de São Paulo, pela liberação para participação na I Jornada Internacional de Filosofia da Educação na FEUSP, em outubro de 2014.

Aos funcionários da Pós e da biblioteca da FEUSP, pelas informações e orientações necessárias à realização do trabalho.

E, finalmente, à Taís, por "tomar o caminho errado" e decidir compartilhar as alegrias e dores no "pó da estrada". 
A democratização, no âmbito da escola, não será alcançada sem que cada escola organize o seu próprio projeto educativo com um insistente esforço de revisão conceitual. Este é o ponto essencial da autonomia escolar.

José M. P. Azanha 


\section{RESUMO}

LOIOLA, Eder Marques. Uma ideia da autonomia da escola na obra de José Mário Pires Azanha. 2016. 121f. Dissertação (Mestrado) - Faculdade de Educação, Universidade de São Paulo, São Paulo, 2016.

A presente dissertação discute o conceito de autonomia da escola na obra do educador José Mário Pires Azanha (1931-2004). A interpretação exposta no trabalho sugere que a expressão era geralmente usada pelo autor num sentido programático, associada a uma proposta específica de atribuição de autonomia educativa às escolas. O programa prático veiculado pelo conceito é considerado uma resposta aos impasses institucionais inéditos deflagrados pela democratização do acesso à escola básica de oito anos a partir da reforma Ulhoa Cintra (1967-70). A argumentação recorre à articulação da ideia de autonomia da escola com outras noções presentes em escritos variados do autor a respeito das avaliações da qualidade do ensino público, em suas considerações acerca da pesquisa educacional e das propostas de formação de professores, entre outros tópicos. Tais conexões conceituais indicam o propósito de Azanha de destacar aspectos das novas condições de ensino interessantes ao encaminhamento das alegadas dificuldades da escola pública democratizada.

Palavras-chave: Autonomia da escola; Azanha; democratização do ensino. 


\begin{abstract}
LOIOLA, Eder Marques. An idea of school autonomy in the works of José Mário Pires Azanha. 2016. 121f. Dissertação (Mestrado) - Faculdade de Educação, Universidade de São Paulo, São Paulo, 2016.

This dissertation aims to discuss the concept of school autonomy in the works of educationist José Mário Pires Azanha (1931-2004). The interpretation exposed herein suggests that the term was typically employed by the author program-wise, i.e., associated with a particular proposal of educational autonomy assignment to schools. The practical program conveyed by the concept is considered to be an answer to the unprecedented institutional bottlenecks brought about by the democratization of the access to the eight-year Elementary School after the Ulhoa Cintra (1967-1970) reformation. The argumentation is supported by the connection of the idea of school autonomy with other assumptions from several of Azanha's writings about quality assessments in the public school, concerns regarding educational research, and teacher-training proposals, among others. Such conceptual connections demonstrate Azanha's intent to highlight the aspects of valuable new learning conditions when following-up on alleged shortcomings presented by the democratized public school.
\end{abstract}

Keywords: School autonomy; Azanha; Democratization of Education. 


\section{SUMÁRIO}

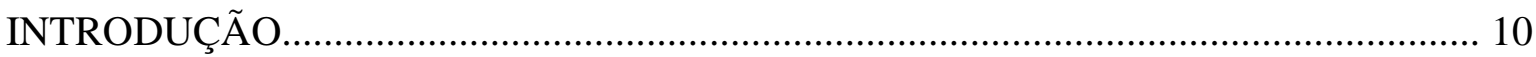

1. UM USO PROGRAMÁTICO DA “AUTONOMIA DA ESCOLA”............................... 16

1.1. A autonomia da escola como condição da melhoria do ensino................................ 22

1.2. Autonomia da escola: alternativa para a "má qualidade" do ensino público?.......... 27

2. UMA NOVA IMAGEM DA ESCOLA DEMOCRATIZADA.................................... 39

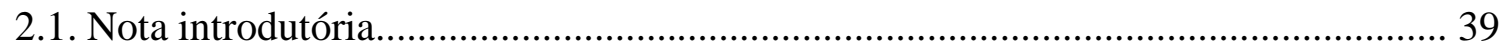

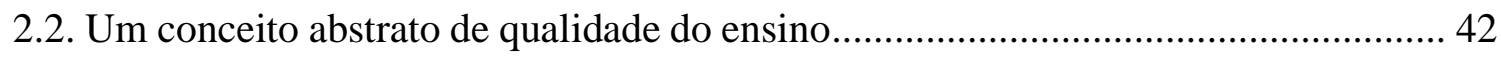

2.3. A discussão de pressuposições supostamente absolutas......................................... 50

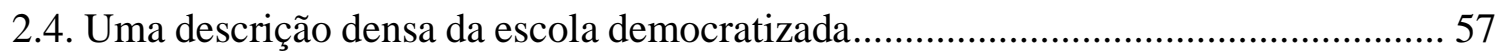

2.5. Diferenças significativas da escola democratizada: coordenadas conceituais........... 65

3. ALÉM DO MÉTODO: VIDA ESCOLAR E AUTONOMIA DA ESCOLA................... 75

3.1. O baconismo na educação: as tecnologias educacionais......................................... 77

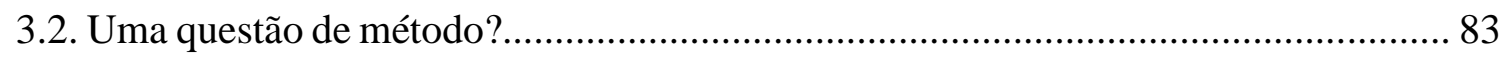

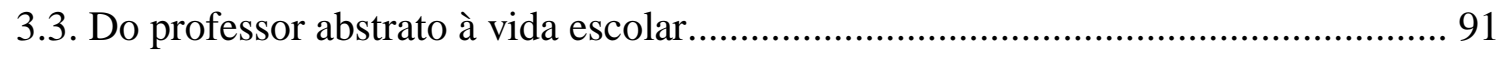

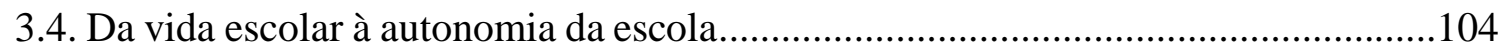

CONSIDERAÇÕES FINAIS: RESPONSABILIDADE, O PRESSUPOSTO ÉTICO DA

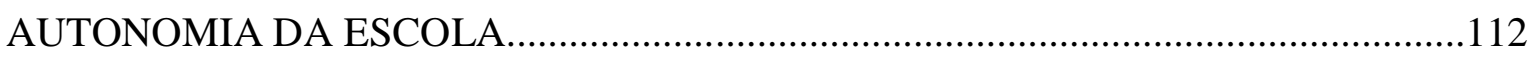

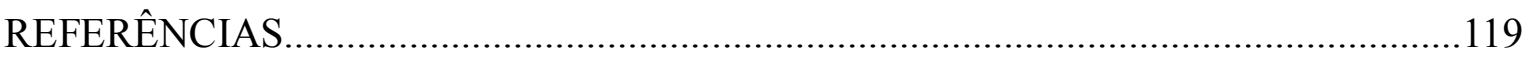




\section{INTRODUÇÃO}

A causa vencedora agradou aos deuses, mas a causa vencida agrada a Catão.

Catão

Num texto em homenagem a Walter Benjamin, Hannah Arendt recorre a uma bela imagem para definir o estilo característico de relacionamento de seu amigo com as obras do passado. Segundo ela, Benjamin teria se dado conta de que as experiências condensadas nas obras antigas não eram mais capazes de exercer autoridade sobre o presente. A sabedoria da tradição que, até então, distinguira nas obras antigas o "positivo do negativo", o "ortodoxo do herético", "o que é obrigatório e relevante dentre a massa de opiniões e dados irrelevantes", mostrava-se impotente no obscuro começo do século XX (ARENDT, 2008, p. 215). Nesses "tempos sombrios", o passado não podia mais "organizar" e "sistematizar" as experiências dos homens no mundo. Entretanto, continua Arendt, a percepção do fim da tradição não teria levado Benjamin a, resignado, desistir das obras do passado. Em vez disso, ele procura uma nova forma de se relacionar com as obras antigas: as citações. Como a sabedoria do passado não podia mais se apresentar como uma narrativa sistemática e organizada transmissível ao presente, restava-lhe arrancar "fragmentos de pensamento" de seu contexto original e citá-los de maneira assistemática e "desconcertante" ao presente (2008, p. 209)

$\mathrm{Na}$ tradução poética dessa interpretação, Arendt compara o estilo de pensamento de Benjamin a uma pescaria peculiar. Trata-se de uma cena inspirada justamente na leitura de um fragmento de A Tempestade, de Shakespeare. O trecho, citado por Arendt (2008, p.208), faz referência ao corpo do pai de Ferdinando perdido no fundo do mar:

A cinco braças jaz teu pai,

De seus ossos fez-se coral,

Essas são pérolas que foram seus olhos.

Nada dele desaparece

Mas sofre uma transformação marinha

Em algo rico e estranho. 
Para Arendt, a sorte desse corpo no fundo do mar ilustra a maneira como Benjamin relacionava-se com o passado. Embora desintegrado, o corpo do pai de Ferdinando não "desaparece". Ele antes "sofre uma transformação marinha", e algumas de suas partes transfiguram-se "em algo rico e estranho". Na metáfora, o corpo corresponde, obviamente, ao passado, tal como Benjamin o compreendia em seu tempo. Embora o passado não se apresentasse mais de maneira orgânica e sistemática na forma de uma tradição, nem por isso desaparecera. Seus fragmentos, devido à ação do tempo, transformaram-se em "algo rico e estranho" como "pérolas" que poderiam ser citadas ou, na linguagem de Arendt, trazidas à tona do tempo presente. Embora fragmentárias, tais pérolas talvez apresentassem uma "força transcendente" capaz de abalar as certezas e consensos do presente. Como lembra Arendt, Benjamin dizia que as citações em sua obra eram como "assaltantes à beira da estrada que fazem um assalto armado e aliviam um ocioso de suas convicções” (2008, p.209). Nessa condição de partícula descontextualizada e "estranha", o passado poderia lançar uma tênue luz sobre os tempos sombrios. Benjamin seria assim um "pescador de pérolas" na noite dos tempos que antecederam o nazismo.

Como o título sugere, esta dissertação de mestrado trata dos usos que José Mário Pires Azanha (1931-2004) faz da expressão "autonomia da escola" em sua obra. Que interesse a homenagem de Arendt a Benjamin pode apresentar a um assunto aparentemente tão remoto quanto esses escritos de um professor e estudioso da educação relativamente pouco conhecido? Ao contrário do que parece, as palavras iniciais deste trabalho não pretendem ser exercícios retóricos para disfarçar dúvidas a respeito do que dizer sobre as considerações que seguem - embora esse risco, claro, não deva ser descartado. Mais do que um capricho de erudição, a imagem de Arendt parece-nos uma forma de expressão poderosa para definir a relevância dos escritos de Azanha e, consequentemente, justificar a pertinência de um trabalho sobre um dos tópicos mais importantes de sua obra. Abusando da metáfora da autora, temos a convicção de que, a exemplo das pérolas ricas e estranhas colecionadas por Benjamin, muitas das ideias e intuições de Azanha apresentam uma "força transcendente" capaz de abalar certezas, consensos, slogans, chavões e outras formas de expressão correntes nos debates educacionais do presente. Justamente por sua "estranheza", seus pontos de vista são capazes de desconcertar interpretações desgastadas sobre a má qualidade do ensino público, as propostas de formação de professores, a vida escolar, entre outros tópicos frequentemente visitados pelo autor. A situação não é diferente se 
considerarmos suas propostas com relação à autonomia da escola, uma "pérola" que pretendemos resgatar das águas turvas do esquecimento neste trabalho.

A relevância dos escritos de Azanha parece contrastar com a divulgação mais ou menos restrita de sua obra. Seu nome é, hoje, relativamente desconhecido entre os professores que atuam na escola pública, mesmo no estado de São Paulo, onde foi importante ator político na polêmica medida de expansão de vagas no ensino ginasial na reforma Ulhoa Cintra, em 1967. Suas ideias, por sua própria natureza, raramente circulam em revistas de divulgação que, em geral, consagram métodos e tecnologias didáticas mais ou menos afins aos modismos pedagógicos do momento. Mesmo nos cursos de licenciatura ministrados no ensino superior, seus escritos dificilmente ocupam o lugar de referências obrigatórias. Enfim, a obra de Azanha, como que por uma ironia do destino, não poderia estar mais distante daquela instituição e dos profissionais que ocuparam quase integralmente suas preocupações na atividade pública e acadêmica: a escola pública e os professores.

É possível que a história da recepção da obra de Azanha encontre muitas versões semelhantes entre outros nomes de educadores e pensadores de temas educacionais no Brasil. Essa constatação, no entanto, não diminui o prejuízo que essa lacuna representa para a formação de professores da educação básica, sobretudo daqueles interessados em atuar nas redes públicas de ensino. Avesso ao discurso especialista que oferece panaceias pedagógicas com ares de cientificidade, esse grande educador antes punha em questão certezas e adesões açodadas em torno de temas banalizados nas discussões educacionais de sua época. Como disse certa vez, sua atitude representava um esforço de mostrar a complexidade dos problemas em pauta, de modo a evitar que se tomassem "lamparinas por sois" (AZANHA, 2001, p. 14). Nenhuma atitude poderia ser mais conveniente para a formação de professores destinados a lecionar na escola pública acessível a todos, uma entidade considerada por ele uma "novidade institucional" que, mais do que certezas dogmáticas, exigia a responsabilidade e o comprometimento de seus agentes com uma proposta educativa aberta à "investigação e busca" (AZANHA, 2006, p. 61; p. 63).

Não podemos negar que muitas das ideias do autor são, por assim dizer, "datadas" pelos debates educacionais que manteve em vida - o corpo no fundo do mar não apresenta mais sua integralidade orgânica. Boa parte deste trabalho, na verdade, trata de questões que poderiam ser corretamente enquadradas nessa categoria, a começar pela própria ideia de autonomia da escola. Embora candente no fim da década de 1980 e no decênio de 1990, esse é um assunto que atrai pouca atenção hoje em dia. Mesmo os sindicatos e entidades de classe 
similares, que já empunharam essa bandeira em contextos anteriores, apenas eventualmente lembram-se de reivindicar autonomia para as unidades escolares, geralmente quando as medidas da administração educacional interferem na organização de suas horas de trabalho ou no arranjo da carreira. Poderíamos também classificar de anacrônicas as ressalvas de Azanha aos argumentos dos críticos da democratização do ensino ginasial na década de 1970, segundo os quais a abertura maciça de vagas teria causado a "queda do nível" do ensino público. Com efeito, a garantia do acesso e permanência universal de todos na escola básica é reconhecida hoje como um direito público subjetivo mais ou menos a salvo de oposições acaloradas. Onde estaria então a "força transcendente" dos escritos de Azanha? Se os temas desta dissertação não podem ser simplesmente apresentados como soluções a problemas urgentes do presente, por que tais "pérolas" devem ser trazidas à tona?

Mais importante do que aquilo que diz, no entanto, é o estilo de dizer de Azanha que parece algo "rico e estranho" para os tempos atuais. Embora inseparável de suas afirmações a propósito de problemas mais ou menos superados pelo tempo, o estilo característico de Azanha de abordar os problemas é talvez o grande responsável por transformar sua obra num clássico precoce da educação brasileira (BOTO, 2012). Uma das definições oferecidas por Italo Calvino para caracterizar uma obra clássica descreve-a como "um livro que nunca terminou de dizer aquilo que tinha para dizer" (1993, p. 11). De fato, esse parece ser o caso dos escritos do nosso autor, mesmo quando atinentes a temas eventualmente vistos como ultrapassados. Como afirma Carvalho a propósito de um texto sobre a ideia de democratização do ensino tido pelo próprio Azanha como "datado", "a forma pela qual [ele] abordara o tema central do artigo transcende a polêmica histórica e pode ser de grande interesse como estilo de investigação e análise de discursos pedagógicos" (CARVALHO, 2013, p. 88). O comentário refere-se ao esforço de Azanha em mostrar que a aparente unânimidade em torno da adesão aos ideais de democratização escondia profundas divergências programáticas no que diz respeito ao conceito de "democratização do ensino". Nesses termos, é como se, visto retrospectivamente, o debate em torno da democratização apresentasse um interesse renovado devido à "transformação marinha" do tempo.

Este trabalho foi escrito seguindo a inspiração de interpretação semelhante a respeito do valor das ideias do autor acerca da autonomia da escola. Sem qualquer pretensão de restaurar a validade inequívoca de suas afirmações para os tempos atuais, procuramos destacar nos escritos do autor um uso interessante da noção de autonomia da escola articulado com outros conceitos centrais de sua obra, presentes por exemplo nas discussões 
a respeito da democratização do ensino, nas ressalvas à estigmatização do ensino público, nas críticas ao abstracionismo pedagógico e nas considerações sobre as propostas de formação de professores. Nesse sentido, procuramos mostrar que, independentemente de sua viabilidade atual, o uso programático da noção de autonomia da escola por Azanha guarda conexões conceituais interessantes com seu estilo geral de "investigação e análise dos discursos pedagógicos", se quisermos recorrer novamente aos termos de Carvalho. E é justamente essa forma de considerar as ideias feitas sobre a vida escolar que julgamos uma contribuição "rica e estranha” à consideração das práticas da escola pública contemporânea. Assim, ainda que muito do que se encontre dito aqui não seja imediatamente transponível para a situação educacional presente, resta ainda a lucidez incomum de um autor que entreviu na concessão de autonomia às escolas uma resposta digna à crise do padrão de ensino ginasial deflagrada pela expansão da escola básica a partir da década de 1970. O êxito deste trabalho será maior quanto mais resplandecente tornar o brilho original da pérola de Azanha.

\section{Alguns esclarecimentos preliminares}

Como já indicamos, procuramos sugerir uma leitura da ideia de autonomia da escola à luz de outros conceitos empregados por Azanha. Nesses termos, esforçamo-nos por destacar que sua proposta não se assemelhava à vala comum de slogans e "palavras sagradas" a respeito do assunto, discutidos já no primeiro capítulo. Ao empregar a expressão, Azanha, segundo nossa interpretação, pressupunha uma série de noções a respeito da novidade da escola democratizada, da vida escolar, da formação de professores etc. Neste trabalho, procuramos deixar evidente as conexões conceituais entre sua proposta de autonomia da escola e outros tópicos de sua obra. A nosso ver, tais conexões podem lançar luz sobre o uso programático da expressão. Esse propósito teve implicações para o percurso delineado no trabalho que talvez mereçam algumas poucas palavras na forma de justificativas.

Para mostrar a trama conceitual do uso de autonomia, vimo-nos inclinados a retomar temas eventualmente já discutidos em outras partes do trabalho mas necessários para o esclarecimento do ponto em questão. Daí a recorrência de certos assuntos na dissertação, a exemplo das críticas de Azanha à noção abstrata de qualidade do ensino e sua ênfase na novidade institucional representada pela escola democratizada, dentre outros assuntos. Por esse mesmo motivo, o trabalho reúne capítulos que, embora coerentes, apresentam 
discussões de pontos particulares dificilmente integráveis numa argumentação linear e fluida, como seria o caso de uma narrativa histórica voltada à reconstituição dos usos da autonomia da escola por Azanha em diferentes contextos. Enfim, à semelhança das Investigações filosóficas de Wittgenstein (1999, p. 25), este trabalho é como um “álbum” de viagens: uma compilação de paisagens - algumas mais recorrentes do que outras, embora vistas de um ângulo diverso a cada vez... 


\section{CAPÍTULO 1 - UM USO PROGRAMÁTICO DA “AUTONOMIA DA ESCOLA"}

Uma palavra tem o sentido que lhe foi dado por alguém.

Wittgenstein, O livro Azul

A autonomia da escola é, sem dúvida, um dos temas centrais da obra de José Mário Pires Azanha. Não por acaso, diferentes estudos sobre o autor, orientados por variados propósitos, ocuparam-se de algum modo do tema ${ }^{1}$. Por mais divergentes que possam ser as interpretações já formuladas, todas elas devem concordar em que a autonomia educativa, de acordo com Azanha, é - ou pelo menos deveria ser - uma prerrogativa das escolas. Não se encontram, na obra do autor, reivindicações de autonomia didática ao professor desvinculado do contexto institucional de uma escola, nem mesmo o reconhecimento da autonomia como ideal pedagógico a orientar a formação da personalidade dos alunos. A autonomia, em Azanha, é um conceito referido sempre às escolas. Daí que o termo figure em sua obra associado à escola na expressão "autonomia da escola"2.

Esse esclarecimento preliminar é importante. Afinal, o termo "autonomia", já na época de Azanha, era recorrente no discurso educacional, sendo usado nos mais diversos sentidos e em diferentes contextos. Ainda hoje a "autonomia" do aluno ora tem sido

\footnotetext{
${ }^{1}$ A obra e a atuação política de Azanha foram objeto de estudo de alguns trabalhos acadêmicos, dos quais destacamos os seguintes: LIMA, Raymundo de. Educação no Brasil: o pensamento e a atuação de José Mário Pires Azanha. Tese (Doutorado em Educação) - Faculdade de Educação da Universidade de São Paulo, São Paulo, 2005; GORDO, Nívia. História da Escola de Aplicação da FEUSP (1976-1986): a contribuição de José Mário Pires Azanha para a cultura escolar. Tese (Doutorado em Educação) - Faculdade de Educação da Universidade de São Paulo, Sâo Paulo, 2010; PAULINO, Clóvis Edmar. José Mário Pires Azanha: uma introdução a um pensamento de significativa contribuição ao debate educacional brasileiro (políticas públicas e práticas escolares). Dissertação (Mestrado em Educação) - Faculdade de Educação da Universidade de São Paulo, São Paulo, 2010; CURY, Ariam José Ferreira de Castilho. Azanha e a democratização do acesso ao ensino: 1967-1970. Dissertação (Mestrado em Educação) - Faculdade de Educação da Universidade de São Paulo, São Paulo, 2012.

No geral, os trabalhos sobre a obra de Azanha procuram esclarecer seus escritos referindo-os ao contexto educacional ou político de sua formulação (Cury, Gordo e Lima). Outra abordagem usual é o comentário de aspectos de sua obra e sua aproximação de escritos de outros autores sobre temas educacionais (Paulino, Lima). Para uma introdução completa à obra e atuação pública de Azanha, conferir CARVALHO, José Sérgio Fonseca de. José Mário Pires Azanha. Coleção Educadores. Recife: Fundação Joaquim Nabuco, Editora Massangana, 2010.

${ }^{2}$ Neste trabalho, como nas obras de Azanha e de outros autores tributários da filosofia analítica em educação, usamos as aspas tanto para indicar a citação de trecho de determinado autor no corpo do texto quanto para acentuar determinados usos da expressão assinalada. No primeiro caso, o trecho entre aspas é seguido da devida referência. No segundo caso, as expressões entre aspas não são seguidas da referência habitual, aparecendo isoladas no texto. Como se comprovará pela leitura do texto, boa parte das expressões entre aspas destacadas a fim de chamar atenção para seu sentido, conforme o segundo caso, são de autoria do próprio Azanha ou alusões do autor a termos correntes nos debates sobre a escola pública - tais como, "qualidade", "ensino", etc.
} 
postulada como objetivo do processo de aprendizagem, ora tem sido identificada à própria situação do aluno num contexto pedagógico não diretivo. Por vezes, o termo tem sido usado para se referir à liberdade reivindicada pelos professores da escola para, por exemplo, realizar suas escolhas curriculares ou seus procedimentos de ensino. Em outros casos, a "autonomia" do aluno na realização de dada atividade serve de critério para definir sua posição numa determinada escala de desenvolvimento cognitivo. A "autonomia" pode também ser usada para indicar um atributo do cidadão que a escola espera formar. Esse modesto exemplário de usos de "autonomia" mostra a polissemia a que a expressão está sujeita em contextos educacionais. A situação não era diferente à época de Azanha, que assinalava que a palavra "autonomia", em educação, "foi sofrendo um alargamento de significados" (AZANHA, 1995, p. 146).

O próprio Azanha, consciente do risco de banalização do uso de "autonomia" nos debates educacionais das décadas de 1980 e 1990, dedicou-se a distinguir seu emprego específico do termo do uso generalizado da expressão como "palavra sagrada" naquele contexto (AZANHA, 1995, p.131-132). A sacralidade atribuída à palavra é justificada, nos termos de Lovejoy ${ }^{3}$, pelo fato de que certas conotações positivas da noção de autonomia, como sua vinculação ao ideário democrático em voga, estavam “de acordo com as crenças prevalecentes, com a escala de valores e com os gostos" do período, de tal modo que ninguém "teria a ousadia de se colocar contra a autonomia da escola ou de pôr em dúvida sua gestão democrática” (AZANHA, 1995, p.132). De acordo com Azanha, a sacralização da "autonomia" acabou por esvaziá-la de sua força propositiva como indicação de soluções aos problemas educacionais, reduzindo-a a um slogan educacional (AZANHA, 1995, p.132). Assim, embora a princípio o uso indiscriminado do termo nessa condição não representasse

\footnotetext{
${ }^{3}$ A qualificação da palavra autonomia como "sagrada" por Azanha representa a extensão de um conceito do historiador da filosofia Arthur Lovejoy para as discussões educacionais brasileiras do período. Para Lovejoy, segundo a interpretação de Azanha, uma palavra sagrada associa-se às ideias, valores ou convicções centrais de uma época, constituindo referência fundamental para o estudo da mentalidade de um período histórico. Ver AZANHA. J.M.P. Autonomia, um reexame in Educação: temas polêmicos. SP, Martins Fontes, 1995, pp. 131-132. A preocupação de Azanha em distinguir seu uso de autonomia do uso comum do termo nos debates educacionais do período parece levar em conta a recomendação de Lovejoy do estudo histórico da "semântica filosófica", ou seja, o "inventário dos vários matizes de significado" de uma expressão. A preocupação do historiador estadunidense refere-se à reconstituição histórica da multiplicidade de significados de uma expressão corrente ou "sagrada" numa época e o aparecimento de "associações confusas" decorrentes dessa ambiguidade: "É em grande parte por causa de suas ambiguidades que simples palavras são capazes dessa ação independente como forças na história. Um termo, uma frase, uma fórmula que se torna corrente ou ganha aceitação porque um de seus significados ou um dos pensamentos que sugere se torna congenial às crenças predominantes, aos padrões de valor, aos gostos de certa época pode ajudar a alterar crenças, padrões de valor e gostos, porque outros significados ou implicações sugeridas, não claramente distinguidas pelos que os empregam, se tornam gradualmente os elementos dominantes de sua significação." Cf. LOVEJOY, Arthur. A grande cadeia do ser. São Paulo: Editora Palindromo, 2005, p. 23.
} 
um problema, Azanha reconhecia o risco de que a sacralidade da palavra ofuscasse aspectos e usos do conceito potencialmente interessantes ao tratamento de problemas educacionais. Nessas circunstâncias, torna-se compreensível a preocupação do autor, desde seus primeiros escritos sobre o assunto, em distinguir com clareza um uso próprio do conceito.

Tal distinção é ilustrada exemplarmente no texto Autonomia da escola, um reexame, de 1992. ${ }^{4}$ Nesse texto, Azanha apresenta uma reconstituição histórica dos significados atribuídos à autonomia nos discursos educacionais brasileiros desde o Manifesto dos Pioneiros, de 1932 - procedimento repetido em outras ocasiões. ${ }^{5}$ Em linhas gerais, o autor demonstra que o uso do termo não se associa explicitamente à instituição escolar na tradição dos discursos educacionais. No Manifesto dos Pioneiros, em que se verifica sua primeira ocorrência de relevância pública, a autonomia apareceria associada sobretudo à proposta de criação de um fundo nacional para financiamento de gastos educacionais independente das mudanças de orçamento dos diferentes governos. A segunda ocorrência publicamente relevante da noção de autonomia constaria do Código de Educação do Estado de São Paulo, de 1933, referindo-se à autonomia didática do professor. Por fim, as Leis de Diretrizes e Bases da Educação Nacional promulgadas em 1961 (Lei n. 4.024) e 1971 (Lei n. 5692) apenas sugeririam a relação entre autonomia e instituição escolar por meio da fixação da norma de que cada estabelecimento de ensino deveria se organizar autonomamente com base em regimento próprio. Mesmo nesse caso de menção tácita, a autonomia, de acordo com Azanha, não se associaria de fato à instituição escolar como proposta de "indicação de soluções" (1995, p.132), uma vez que essa determinação era anulada por dispositivos presentes nas próprias leis que permitiram o estabelecimento posterior de regimentos comuns pelos respectivos sistemas de ensino.

Nesse ponto, podemos já indagar por que Azanha se preocupa em distinguir seu uso específico do termo autonomia como prerrogativa da escola do uso corrente da palavra no debate educacional. Trata-se simplesmente de um esforço de elucidação do conceito de autonomia? Azanha estaria empenhado em esclarecer $o$ significado usualmente aceito da expressão? Talvez seja razoável supor que o zelo do autor nessa distinção ultrapasse sua reconhecida clareza estilística. Na verdade, o que parece estar em jogo nesse caso é a

\footnotetext{
${ }^{4}$ Originalmente, o texto foi preparado para uma palestra na data indicada, sendo publicado posteriormente em AZANHA, J.M.P. Autonomia, um reexame in Educação: temas polêmicos. SP, Martins Fontes, 1995. Em muitas referências deste trabalho, aliás, a data da publicação original do texto referido pode não ser a mesma da versão consultada, frequentemente republicada em um dos livros do autor.

${ }^{5}$ Esse tipo de abordagem se repete em Proposta pedagógica e autonomia da escola in AZANHA, J. M. P., A formação do professor e outros escritos. São Paulo, Senac, 2006.
} 
enunciação de um uso programático do conceito, na acepção que lhe empresta Scheffler. A compreensão desse emprego distinto de autonomia requer, portanto, algumas considerações a respeito das análises das definições em educação empreendidas por esse autor ${ }^{6}$.

Para Scheffler, as definições programáticas integram as definições gerais em educação, ou seja, aqueles enunciados voltados a definir certas noções educacionais que se encontram destacados de uma teoria científica. Assim, as definições ou conceitos gerais, em Scheffler, diferenciam-se das definições ou conceitos científicos. Enquanto os últimos caracterizam-se pelo uso de um vocabulário especializado, um complexo articulado de conceitos pertencente a uma área da pesquisa científica, as primeiras recorrem à linguagem ordinária para o tratamento de temas educacionais. As definições gerais podem figurar nos mais diversos contextos discursivos, tais como em afirmações "referentes a um currículo, em enunciações de programas e objetivos [educacionais], em interpretações de educação dirigidas ao público em geral e em debates sobre política educacional" (SCHEFFLER, 1974, p. 21).

Diferentemente das definições gerais descritivas, as definições ou conceitos gerais programáticos não pretendem simplesmente esclarecer o significado consagrado pelo uso de uma determinada expressão num determinado contexto - como, por exemplo, no caso em que oferecemos uma definição geral da "avaliação" escolar como "a mensuração ou estimativa da aprendizagem dos alunos". Trata-se antes de propor enunciados que visam, com sua difusão, a "dar expressão a programas de ação". Desse modo, as definições programáticas apresentam um papel prático que as distingue das demais definições gerais. Esse papel tem a ver com sua pretensão de influenciar a "prática social" e os "hábitos de espírito", extrapolando assim os propósitos discursivos imediatos do contexto em que são introduzidas. As definições programáticas operam referindo certas situações ou objetos a "princípios gerais de ação" ou formas de "tratamento prático" reconhecidos socialmente e

\footnotetext{
${ }^{6}$ SCHEFFLER, Israel. A Linguagem da Educação. São Paulo, Saraiva/EDUSP, 1974. Cf. pp. 28-32. Embora Scheffler trate das definições de certos termos e expressões em educação, julgamos que a expressão autonomia da escola em Azanha não é empregada geralmente como uma "definição" ostensiva, mas sim como um "conceito" ou uma "noção". Ao adotarmos este termo, procuramos recusar a noção de que o uso da expressão autonomia da escola por Azanha fundamente-se numa definição prévia e exata da abrangência de seu significado. Não obstante seu empenho em distinguir claramente seu uso do emprego generalizado do termo, é o uso mesmo da autonomia em sua obra que consolidará um significado que, embora não definido explicitamente, é conveniente a seus propósitos. A referência a Scheffler, contudo, não é arbitrária. Esse autor é citado por Azanha em diversas passagens de sua obra, como, por exemplo, em suas discussões sobre o caráter exaustivo do método ou sobre o papel dos slogans educacionais (cf. AZANHA, 1987, p. 76; 2006, p. 15). Ademais, a identificação do uso programático dos conceitos educacionais nos parece igualmente uma consideração de Scheffler cara a Azanha.
} 
cristalizados no uso de certos termos mobilizados no ato de definição (SCHEFFLER, 1974, p.32).

A fim de tornar mais claro o estatuto específico de uma definição ou conceito programático, tomemos como exemplo a noção de "ensino de qualidade"7. A definição ou conceituação do que seria um ensino de qualidade frequentemente é usada para apresentar um programa educativo prático ${ }^{8}$. A expressão "de qualidade" é geralmente mobilizada por sugerir um "princípio geral de ação" ou um modo de "tratamento prático" positivamente valorizado em nossas formas de pensar e em nossos hábitos intelectuais (SCHEFFLER, 1974, p.32). Quando, por conseguinte, definimos "ensino de qualidade" como aquele que aumenta consideravelmente o rendimento de alunos em testes padronizados, não estamos preocupados simplesmente em explicar o sentido normalmente reconhecido dessa noção. Nosso interesse reside antes em sugerir um programa de ação que concebe o ensino de qualidade como o conjunto mensurável de ações que aumentam o desempenho de estudantes em testes padronizados. Nessa acepção, qualquer ação pedagógica cujos resultados sejam incapazes de fornecer indicadores redutíveis a grandezas matemáticas ou traduzíveis em desempenhos específicos dos aprendizes dificilmente poderia ser identificada como exemplo de um "ensino de qualidade". Nesse e em outros casos, a definição do "ensino de qualidade" procura fixar, ampliar ou reduzir a abrangência do conteúdo da expressão de modo a manter, estender ou restringir o tratamento valorativo do ensino a um conjunto variável de práticas educativas. Em suma, trata-se de um uso da expressão que procura induzir certas consequências práticas.

Retomemos agora a própria noção de autonomia da escola na obra de Azanha para sublinhar seu estatuto geral e programático. Em primeiro lugar, o emprego de "autonomia" em associação à escola não recorre a um uso especializado ou científico do termo. Como

\footnotetext{
${ }^{7} \mathrm{O}$ exemplo pressuposto aqui foi retirado de uma coluna sobre educação a respeito da relação entre "qualidade de ensino" e a remuneração do professorado, disponível em http://veja.abril.com.br/011008/p_091.shtml. (Acessado em 23/04/2014). O trecho a seguir é particularmente interessante para os propósitos da nossa discussão: "Não é preciso conjeturar sobre o impacto dos salários sobre a qualidade do ensino - basta medilo. E há pencas de estudos empíricos que fazem exatamente isso: verificam o desempenho de centenas de milhares de alunos em testes padronizados, computam os salários de seus professores e o volume de investimentos de suas escolas, adicionam outras variáveis de interesse - nível de educação e financeiro dos pais dos alunos, experiência do professor, infraestrutura da escola etc. -, jogam tudo em uma ferramenta de análise estatística e medem a importância de cada variável para o aprendizado do aluno.”(grifos nossos) ${ }^{8}$ Embora tenhamos destacado a noção de uso das expressões como definições nesta e em outras passagens, nunca é ocioso lembrar que, de acordo com Scheffler, não é a forma literal da expressão que constitui critério para a qualificação de uma definição como programática. Uma mesma fórmula pode constituir uma definição descritiva ou programática dependendo de seu uso num determinado contexto educacional. Cf. SCHEFFLER, ob. cit., p.20.
} 
vimos, o autor, na revisão do significado de autonomia nos debates educacionais, diferencia seu próprio emprego dos usos precedentes da palavra, tomando-a, contudo, em seu uso corrente na linguagem ordinária. Do mesmo modo, os usos da autonomia da escola por Azanha ocorrem em contextos discursivos variados, dificilmente tipificados como científicos em sentido estrito. Por essas razões, a noção de autonomia da escola em Azanha constitui caso de uma definição ou um conceito geral em educação.

O ponto fundamental, no entanto, é que as formulações do autor representam casos de afirmação programática da autonomia da escola. O esforço de distinção conceitual empreendido por Azanha com relação ao emprego do termo "autonomia", ou seja, como prerrogativa da escola, tem a ver com a proposição de um uso programático específico para tal conceito. Evidentemente, o exercício de distinção entre o emprego do conceito como prerrogativa das escolas e suas ocorrências variadas nos discursos educacionais não atende prioritariamente ao propósito de esclarecer o uso prévio de autonomia nos debates pedagógicos. Pelo contrário, Azanha admitia a originalidade de seu emprego da autonomia associada às escolas. A restrição do termo autonomia à escola corresponde, portanto, à exigência de formulação de um programa prático definido, deliberadamente implicado no conceito. Assim, a expressão autonomia da escola visa sobretudo a veicular um programa prático de vinculação da autonomia educativa às instituições escolares.

É nesse sentido programático que se deve entender a autonomia da escola como uma "indicação de soluções" (AZANHA, 1995, p.132). Como vimos, Azanha censurava a transformação da autonomia em "palavra sagrada", afirmando que seu uso indiscriminado a teria esvaziado de sua força indicativa de soluções para os problemas educacionais (AZANHA, 1995, p. 131-132). Em suas palavras, "até o momento", o conceito de autonomia, "escasso nos documentos oficiais", nunca teria assumido "um significado que fosse mobilizador do magistério e indicativo de uma direção na solução de problemas educacionais" (AZANHA, 1995, p. 134, grifos nossos). Ora, ao consignar, ainda que implicitamente, uma tal aspiração ao seu emprego próprio da autonomia como atributo da escola, parece possível afirmar que Azanha procurava não apenas distinguir conceitualmente sua concepção de autonomia da tradição dos debates em educação nacionais, mas sobretudo veicular, por meio de seu uso, uma proposta singular de associação entre autonomia e escola.

\footnotetext{
${ }^{9}$ Trata-se do momento em que tal reconstituição histórica dos significados do termo é empreendida. Já no texto Proposta pedagógica e autonomia da escola, Azanha considera o seu Documento preliminar como o primeiro texto em que a autonomia é empregada como conceito "mobilizador do magistério" e "indicativo de soluções". Cf. AZANHA, 2006, p. 91
} 
Nesses termos, o uso programático sugerido pelo autor pretendia ultrapassar a mera "adesão verbal de todos" provocada pela circulação indiscriminada de "autonomia" como slogan educacional ou "palavra sagrada" das décadas de 1980 e 1990 (AZANHA, 1995, p.120). Como esperamos esclarecer oportunamente, tal associação entre autonomia e instituições escolares não procura simplesmente arregimentar interessados na defesa consensual de uma nova panaceia pedagógica ${ }^{10}$. A “força propositiva” do termo consagrada por Azanha parece residir na apresentação de uma imagem original da vida escolar conveniente ao encaminhamento de certos "problemas educacionais" (AZANHA, 1995, p. 134). Mas qual seria essa proposta? A quais "problemas educacionais" ela representaria uma “indicação de soluções”? Ao que parece, a análise da primeira referência explícita de Azanha à autonomia da escola oferece indícios relevantes para a compreensão desse conceito programático, tal como entendido pelo autor.

\subsection{A autonomia da escola como condição da melhoria do ensino}

A primeira referência expressa de Azanha à autonomia da escola encontra-se no Documento preliminar para reorientação das atividades da Secretaria da Educação do Estado de São Paulo, de 1983 (AZANHA, 1987, pp. 118-131). À época, Azanha ocupava o cargo de chefe de gabinete do secretário de educação Paulo de Tarso Santos, no governo recém-eleito de Franco Montoro (1983-1987). O propósito da publicação oficial, redigida pelo autor e distribuída para exame nas escolas da rede estadual, era "permitir ao magistério a participação numa ampla discussão sobre questões atuais de educação capaz de oferecer subsídios a uma atuação do governo de forma mais sensível a pontos de vista não apenas tecnocráticos e de gabinete" (AZANHA, 1987, p. 118). A iniciativa representava um esforço de concretização do direito de participação nas decisões do governo, reivindicado pelas oposições no contexto de redemocratização do país ${ }^{11}$.

O Documento Preliminar apresenta indicações de Azanha a respeito de diversos aspectos do ensino paulista. Entretanto, a melhoria da "qualidade do ensino" destaca-se

\footnotetext{
${ }^{10}$ Ver a função dos slogans educacionais segundo Scheffler, ob. cit., p. 46.

${ }^{11}$ A ideia de que tal conceito teve uma "gênese política" deve-se a CARVALHO, José Sérgio Fonseca de. José Mário Pires Azanha. Coleção Educadores. Recife: Fundação Joaquim Nabuco, Editora Massangana, 2010. A proposta Montoro para a educação e seu contexto político foram objeto de estudo de PEDROSO, Leda Aparecida. Democracia, política e administração educacional. Dissertação (Mestrado em Educação) Universidade Estadual de Campinas, São Paulo, 1991.
} 
como um dos princípios centrais da política educacional proposta no texto (AZANHA, 1987, p.121). De acordo com o Documento Preliminar, o tema da qualidade do ensino público, recorrente nos debates educacionais desde a expansão do ensino ginasial na década de 1970 , não deveria mais se apresentar como uma "simples questão técnica", mas como assunto de "alto interesse público", dada a gravidade das dificuldades enfrentadas nas escolas no momento (1987, p.124). Nessas condições, as medidas de melhoria do ensino público paulista constituiriam um complemento necessário à democratização do acesso à escola de Primeiro Grau iniciada na administração de Ulhoa Cintra (1967-1970), com reconhecido protagonismo do próprio Azanha ${ }^{12}$. Nas palavras do autor:

O descaso pelo magistério e pela escola como instituição educativa fez com que a democratização do acesso se transformasse, em poucos anos, numa fraude pedagógica. Porque, evidentemente, é inadmissível que a democratização do ensino se esgote no esforço do pleno atendimento. É preciso que esse esforço seja complementado por medidas visando à melhoria do ensino (AZANHA, 1987, p. 124 , grifos nossos).

No Documento Preliminar, a autonomia da escola é definida justamente como "uma das condições da melhoria do ensino" (1987, p.130). A autonomia das escolas paulistas, na verdade, é apresentada como condição necessária da "melhoria do ensino" no documento. A exigência de autonomia fundamenta-se no reconhecimento de que apenas as escolas podem remover ou amenizar os problemas que enfrentam e assim aperfeiçoar o ensino que ministram. Essa interpretação opõe-se à centralização das prerrogativas de deliberação e implementação de estratégias de melhoria de ensino pelos órgãos da administração educacional exteriores às escolas, como a Secretaria de Educação e suas ramificações regionais. Azanha, nesses termos, atribui às escolas paulistas a elaboração de planos autônomos de melhoria do ensino adequados às suas particularidades. $\mathrm{O}$ papel conferido à Secretaria da Educação e seus órgãos administrativos reduz-se ao apoio à escola em seu esforço insubstituível de melhoria.

\footnotetext{
${ }^{12}$ Um estudo consistente da atuação de Azanha na Secretaria de Educação de São Paulo na administração Ulhoa Cintra, bem como do processo de implementação da reforma responsável pela unificação e simplificação dos exames de admissão ao ginásio pode ser encontrado em CURY, Ariam José Ferreira de Castilho. Azanha e a democratização do acesso ao ensino: 1967-1970. Dissertação (Mestrado em Educação) - Faculdade de Educação da Universidade de São Paulo, São Paulo, 2012.
} 
Cada escola tem características pedagógico-sociais irredutíveis quando se trata de buscar soluções para os problemas que vive. A realidade de cada escola - não buscada por meio de inúteis e pretensiosas tentativas de "diagnóstico" - mas tal como é sentida e vivenciada por alunos, pais e professores é o único ponto de partida para um real e adequado esforço de melhoria. Nessas condições, é preciso que no âmbito de cada escola - e com a colaboração de todos os recursos da comunidade - sejam explicitados os problemas que impedem a melhoria do ensino e formuladas as suas possíveis soluções. Cada escola deve, pois, ter o seu próprio plano de melhoria, que não será mais do que o seu próprio esforço em corrigir as distorções e os desacertos técnicos, bem como em remover ou atenuar os impedimentos sócio-econômicos de origem extra-escolar que embaraçam uma ação educativa eficaz. (AZANHA, 1987, pp. 124-125, grifos nossos)

A citação expressa com clareza a convicção de que é somente "no âmbito de cada escola" que os "problemas que impedem a melhoria do ensino" podem ser avaliados e eventualmente resolvidos. A razão da autonomia inalienável da escola na melhoria de seu ensino reside, por sua vez, na irredutibilidade de suas "características pedagógico-sociais" a planos padronizados de melhoria elaborados pelos órgãos administrativos da educação. Qualquer reforma do ensino que ignorasse esse fato é caracterizada por Azanha como exemplar da "ilusão" tecnocrática de que as escolas pudessem se beneficiar de planos regionais e centrais de melhoria gestados fora e à distância delas (AZANHA, 1987, p. 125).

Não se deve concluir, todavia, que a autonomia reivindicada às escolas por Azanha implique a total independência das unidades em suas ações pedagógicas. Em diferentes ocasiões, o autor admite a legitimidade de princípios e normas gerais como diretrizes necessárias à orientação das escolas, a exemplo daqueles constantes das Leis de Diretrizes e Bases da Educação Nacional (1995, p.34; p. 120; pp. 226-231). Essas disposições comuns, contudo, não poderiam induzir à homogeneização das peculiaridades "pedagógico-sociais" características de cada escola, fundamentais à formulação de medidas de melhoria do ensino (AZANHA, 1987, pp. 124). Por outro lado, a autonomia proposta por Azanha às escolas não prevê a completa indiferença dos órgãos administrativos a respeito da vida das escolas. No próprio Documento Preliminar e em outras oportunidades, o autor reconhece o papel subsidiário dessas entidades nos esforços de melhoria do ensino promovidos pelas escolas, bem como aponta sua responsabilidade no tratamento de questões como a carreira e a remuneração do magistério (1987, pp. 125-126; pp. 133-142).

O ponto essencial, no entanto, é que a abrangência das políticas públicas e das intervenções dos órgãos administrativos não poderia se expandir a ponto de anular ou reduzir significativamente o espaço propriamente escolar das ações voltadas à melhoria do ensino. É com essa preocupação de delimitar a responsabilidade da escola que o autor lhe atribui 
autonomia. A primeira formulação do conceito de autonomia da escola por Azanha é, portanto, marcadamente programática. A autonomia é reivindicada às escolas sobretudo como condição imprescindível para o empreendimento de melhoria do ensino. Nesse sentido, a autonomia da escola identifica-se com a autonomia necessária à melhoria de seu ensino. No mais, a autonomia é justificada como condição institucional coerente com a realidade singular de cada escola.

Em que pesem as eventuais diferenças no emprego de autonomia da escola em escritos posteriores, o conceito figura invariavelmente na obra de Azanha associado a ambos os tópicos. Para ficar em apenas mais um exemplo, a vinculação entre a autonomia das escolas e a melhoria de seu ensino nos termos compatíveis com sua realidade própria reaparece já no título do texto Melhoria do ensino e autonomia da escola, originalmente publicado em 1988 (AZANHA, 1995, pp 19-30). Mais uma vez, Azanha enfatiza a responsabilidade das escolas pela resolução de seus problemas, devidamente apoiadas pelos órgãos administrativos competentes:

Em primeiro lugar, ninguém poderá fazer pela escola aquilo que só ela pode fazer. Só a escola, com seu diretor, seu corpo docente, seus funcionários, suas associações de pais têm que examinar sua própria realidade específica e local; fazer um balanço das suas dificuldades e se organizar para vencê-las. [...] Qualquer política de melhoria do ensino significa o estímulo à criação de condições e recursos para que as escolas possam melhorar (AZANHA, 1995, p. 24, grifos nossos)

A caracterização geral da autonomia da escola como indicativa de "soluções aos problemas educacionais" (AZANHA, 1995, p.120), exposta acima, pode ser capciosa em sua transparência. Na verdade, a simples definição da autonomia como condição necessária de melhoria do ensino pela escola à luz de suas peculiaridades locais não nos parece suficiente para dar conta da riqueza do tema na obra de Azanha. Consideremos a vinculação entre autonomia da escola e melhoria do ensino. Por que autonomia da escola e melhoria do ensino encontram-se associadas? Que ensino se pretende melhorar? O que seria um problema de ensino? O que quer dizer exatamente "melhorar" o ensino? Enfim, a autonomia da escola pode ser definida abstratamente, ou seja, independentemente dos esforços de melhoria do ensino? Questões semelhantes poderiam também ser endereçadas à afirmação da autonomia da escola como condição conveniente à sua "realidade específica e local" (AZANHA, 1995, p.24). 
Por ora, porém, procuramos responder às indagações a respeito da relação entre autonomia da escola e melhoria do ensino insinuada já na primeira referência de Azanha ao conceito de autonomia e constante em seus escritos sobre o tema. As tentativas de resposta a essas perguntas, a nosso ver, contribuem para a compreensão do conceito de autonomia da escola nos diversos textos de Azanha. Suspeitamos até que o esboço dessas respostas pode abrir uma perspectiva de interpretação interessante, capaz de esclarecer a relação fecunda entre o tema da autonomia da escola e outros tópicos correlatos na obra do autor, tais como as noções de cotidiano e vida escolar e proposta pedagógica, as ideias acerca da formação de professores e mesmo algumas considerações sobre a pesquisa educacional - como pretendemos demonstrar nos capítulos subsequentes.

No fundo, as perguntas levantadas a propósito da relação entre autonomia da escola e melhoria do ensino indicam restrições às tentativas de compreensão abstrata da concepção de autonomia da escola nos escritos de Azanha. Elas põem em questão a validade da formulação genérica e vaga do conceito, abstraída de referências determinadas. Não se trata, evidentemente, de negar a possibilidade de indicação de traços semelhantes das ideias de Azanha sobre o tema em diferentes escritos. As perguntas, contudo, procuram chamar a atenção para o equívoco de se compreender a autonomia da escola como uma ideia referenciada em entidades abstratas como "as escolas", cujo objetivo seria "melhorar o ensino", definido de maneira igualmente abstrata. Nesses termos, o conceito de autonomia da escola em Azanha guardaria certa semelhança, por sua aspiração à universalidade, a uma metodologia pedagógica. Ora, as ressalvas de Azanha quanto à validade de "métodos" e "tecnologias" supostamente universais nos assuntos educacionais recomendam reservas com relação à ideia de autonomia como solução genérica para problemas enfrentados pelas escolas no geral ${ }^{13}$.

Em nossa opinião, não é este o caso. A autonomia da escola seria mais bem definida como um conceito empregado por Azanha para responder a impasses deflagrados pela democratização do acesso ao ensino básico a partir da década de 1970 e a consequente crise de um padrão de ensino característico do ensino público pregresso. Trata-se, portanto, de um esforço de compreensão e possível encaminhamento dos problemas específicos de uma novidade institucional: a escola pública básica acessível à totalidade virtual da população (AZANHA, 2006, p. 61). Desse ponto de vista, os escritos sobre autonomia, embora

\footnotetext{
${ }^{13}$ Tema discutido no terceiro capítulo deste trabalho.
} 
programáticos, não procuram oferecer preceitos metodológicos universais de melhoria das escolas do ensino básico. Parece-nos que as reflexões sobre a autonomia da escola ocupamse, sobretudo, com a interpretação do significado específico da nova escola pública e suas condições de ensino. O "programático" do conceito, assim, refere-se antes à afirmação de uma perspectiva singular da escola básica democratizada ${ }^{14}$ relevante na consideração de suas ações.

A fim de demonstrar a consistência dessa interpretação, comecemos por retomar brevemente os comentários de Azanha sobre a noção de "qualidade" - ou a presunção de sua ausência - na escola pública democratizada. Ao que parece, o entendimento dos argumentos do autor contra a estigmatização da qualidade do ensino público democratizado oferece a oportunidade de afastar a ideia de uma "escola pública" abstrata responsável por um "ensino" também abstrato - e, de resto, ruim. Assim, estaremos em condições de destacar a impertinência de se tratar a autonomia da escola como um conceito referido genericamente à "melhoria" da "qualidade" do ensino público.

\subsection{Autonomia da escola: alternativa para a "má qualidade" do ensino público?}

Em diversos escritos, Azanha põe em questão o diagnóstico de que o ensino das escolas públicas teria perdido em qualidade com a expansão maciça das matrículas no ensino ginasial desde fins da década de 1960. De acordo com esse argumento, defendido à época por segmentos da imprensa, por representantes de escolas privadas e mesmo pelo magistério, o aumento das matrículas, longe de promover a democratização do suposto ensino de qualidade ministrado até então nesses estabelecimentos, teria desencadeado um processo de "massificação" e "deterioração" da escola pública (AZANHA, 1995, p. 15). Nesse sentido, as ações voltadas à facilitação do acesso ao ginásio empreendidas pela administração Ulhoa Cintra em São Paulo (1967-70) $)^{15}$ - na qual Azanha teve importante e polêmica participação

\footnotetext{
14 O termo "democratizada" empregado neste trabalho no lugar de "democrática" parece mais adequado à noção de democratização do ensino de Azanha, discutida a seguir. Em particular, o termo procura afastar a concepção de democracia como prerrogativa das relações pedagógicas internas à escola sugerida pela conotação atual do uso da expressão "escolas democráticas", tal como dela faz uso, por exemplo, SINGER, Helena. República das crianças: sobre experiências escolares de resistência. Campinas: Mercado das letras, 2010.

15 Além do próprio Azanha (1987, pp.110-112), CURY, em trabalho já referido, descreve detalhadamente o expediente adotado pela Secretaria de Educação para a expansão das vagas do ginásio antes da extinção formal do exame de admissão, que só ocorreria com a promulgação da nova LDB em 1971. Até então, havia dois
} 
- corresponderiam, na visão dos críticos, a medidas democráticas apenas em aparência ${ }^{16}$. No fundo, o que estaria em marcha era um processo de empobrecimento e degeneração do ensino em decorrência da abertura abrupta das escolas para parcelas da população até então incapazes de superar os exames de admissão ao ginásio. Numa palavra, o ensino ginasial, inflado em quantidade, teria, justamente por isso, perdido em qualidade. O que se via, portanto, era sua "massificação", e não propriamente sua "democratização".

$\mathrm{Na}$ opinião de Azanha, essas reações à reforma implementada pela administração Ulhoa Cintra manifestavam uma visão elitista do significado da escola pública, em particular do ensino ginasial democratizado. O próprio emprego do termo "massificação" para descrever a abertura da escola revela, para o autor, a ideia de que a "democratização" mesma da escola é a razão da queda da qualidade de seu trabalho pedagógico. Entretanto, a oposição à ampliação do acesso à escola não seria afirmada por seus detratores em termos claros, mas escamoteada em justificativas calcadas num certo "zelo pedagógico" (AZANHA, 1987, p. 41). De fato, a ação política de expansão das matrículas é desqualificada e rotulada de "massificação" a partir de considerações pedagógicas sobre a queda da "qualidade" do “ensino" (1987, p. 41). Em outras palavras, os opositores da medida confundiam critérios políticos e pedagógicos em suas referências ao processo de abertura da escola.

Essa confusão, entretanto, não seria simplesmente um erro cometido pelos críticos em suas tentativas de descrição do significado da reforma de 1967. Trata-se, antes, da

níveis de ensino, separados pelo exame de admissão previsto em lei: o primário e o secundário, dividido em ginasial e colegial. O aluno egresso do primário só se matriculava no secundário se fosse aprovado no exame de admissão realizado pela escola em que o escolar pleiteava uma vaga. Como as escolas, no geral, procuravam selecionar os melhores alunos e garantir certas condições de trabalho, os exames elaborados para a admissão dos candidatos costumavam primar por seu rigor acadêmico. Para facilitar o acesso ao ginásio e, ao mesmo tempo, cumprir a exigência legal, a Secretaria de Educação de São Paulo, por iniciativa de Azanha, centralizou a elaboração da avalição na própria Secretaria, de modo a cobrar no exame apenas os conteúdos esperados da formação primária. Como resultado, o número de alunos legalmente aptos à matrícula aumentou consideravelmente. Segundo Cury, o número de aprovados apenas na capital passou de 35.000, no exame do final de 1967, para 80.000, em 1968. O índice geral de aprovação nesse ano foi de $85 \%$, chegando a superar $90 \%$ em algumas cidades. Cf. CURY, op. cit. p. 39.

\footnotetext{
${ }^{16}$ A associação imediata entre expansão do ensino e precarização de sua "qualidade" é observada por Azanha em autores como Jacques Lambert e Demerval Saviani (cf. 1987, p. 32; 2011, p. 48 e ss.). Entretanto, longe de constituir curiosidade do conhecimento histórico, a ideia de que a expansão do acesso em si mesma é causa do rebaixamento da qualidade do ensino é ainda empregada como argumento para explicar os alegados problemas da escola pública, como no trecho a seguir: "Nunca é demais lembrar que, se analisarmos as políticas públicas em educação nas décadas subsequentes [1960 e 70], veremos que essa a expansão massiva do ensino foi perseguida de maneira tão eficaz que reforçou a precarização da escola pública" Cf. CHIOZZINI, Daniel Ferraz. Memória e história da inovação educacional no Brasil: o caso dos Ginásios Vocacionais (19611969). Tese (Doutorado em Educação) - Universidade Estadual de Campinas, São Paulo, 2010. Ao que parece, a expansão lenta, gradual e segura das vagas da escola pública seria a alternativa indicada para garantir a existência "da escola pública" de excelência nos dias que correm.
} 
afirmação de uma posição específica diante da "democratização" das oportunidades educativas. No texto Democratização do ensino: vicissitudes da ideia no ensino paulista, Azanha (1987) argumenta que o termo "democracia" e a expressão correlata “democratização do ensino", embora gozem de valorização quase unânime, podem ser interpretados e traduzidos em múltiplas práticas e ações, ganhando significados variados de acordo com o contexto histórico e com os agentes - autoproclamados democratas - que as empregam. Trata-se, mais uma vez, de termos com usos programáticos.

$\mathrm{Na}$ história do ensino paulista, Azanha identifica duas noções relevantes e alternativas de "democratização do ensino", associadas a diferentes práticas e eventos: democratização como ampliação do acesso à escola ou democratização como renovação pedagógica. A primeira noção se associaria às experiências históricas da reforma Sampaio Dória, na década de $1920^{17}$, marcada pela ampliação do acesso ao antigo ensino primário, e à própria expansão do ginásio sob a administração de Ulhoa Cintra (1967-70). A segunda noção, por sua vez, encontraria encarnação exemplar no ensino renovado dos Ginásios Vocacionais (1962-70). Em linhas bastante gerais, a renovação caracterizada como democratizante, neste último caso, corresponderia à reordenação das relações pedagógicas internas à escola com o objetivo de estabelecer interações mais igualitárias entre educadores e educandos e, assim, formar indivíduos "democráticos".

Para Azanha, as duas concepções de democratização do ensino não são apenas diversas, mas dificilmente conciliáveis. Enquanto a democratização empregada com referência à expansão de vagas exclui qualquer consideração de ordem estritamente pedagógica, a acepção de democratização associada à experiência dos Ginásios Vocacionais fundamenta-se em noções sobre a relação pedagógica entre professores e alunos no contexto da escola. Não se pode dizer, assim, que as diferentes noções sejam complementares. Pelo contrário, embora em tese não excludentes, ambas disputam, programaticamente, um significado legítimo para o uso de "democratização do ensino". Nesses termos, a democratização das relações pedagógicas preconizada pelos Ginásios Vocacionais não é simplesmente o aspecto "qualitativo" do processo "quantitativo" de expansão das vagas. Com efeito, os dois usos de "democratização do ensino" não se referem a matizes diferentes

\footnotetext{
${ }^{17}$ A interpretação de Azanha do significado da reforma Sampaio Dória é inspirada no trabalho de Jorge Nagle, Educação e Sociedade na Primeira República. Rio de Janeiro: Fundação Nacional do Material Escolar, 1974. Não se trata aqui de discutir a veracidade histórica das afirmações de Nagle nem mesmo de Azanha. O que nos interessa, sobretudo, é o significado atribuído pelo nosso autor à reforma em sua proposta de "democratização" do ensino.
} 
de um único e mesmo processo presumidamente designado pela expressão. Na verdade, a aparente unanimidade em torno da "profissão de fé democrática" encobre profundas divergências no entendimento dos significados da ação democratizadora (AZANHA, 1987, pp. 27-28).

Esse dissenso se revela com clareza na consideração dos pressupostos subjacentes às diferentes propostas de democratização do ensino. Na reforma Ulhoa Cintra, tomada por Azanha como exemplo da noção de democratização como expansão radical das oportunidades educativas, a "democratização" é empregada como conceito político e social, referindo-se à decisão política de expansão das matrículas no ensino ginasial, antes e independentemente de qualquer avaliação de suas possíveis ou efetivas consequências no âmbito pedagógico do ensino. Por outro lado, a concepção de democratização subentendida na pedagogia renovada dos Ginásios Vocacionais constitui paradigma da aplicação de "democratização" como conceito pedagógico, ou seja, como critério para qualificar um tipo de ensino específico, caracterizado essencialmente pela "prática da liberdade" de escolha dos educandos no contexto da relação pedagógica (AZANHA, 1987, pp. 36-42). Nessa perspectiva, a simples abertura de vagas não é suficiente para a "democratização do ensino". $\mathrm{O}$ ensino verdadeiramente democrático seria aquele que se compromete, no plano didático e curricular, com a formação de alunos dotados de "personalidades democráticas", isto é, com o cultivo de hábitos e atitudes pessoais supostamente necessários para a vida democrática, como a liberdade de escolha. Nesse caso, o primado das considerações pedagógicas pode mesmo se opor à decisão política de abertura de vagas nas escolas e concebê-la como "massificação", já que a simples entrada da massa populacional na instituição, além de não garantir a formação de indivíduos aptos à convivência democrática, representa até uma ameaça ao padrão distinto de organização do ensino "democrático"18 (AZANHA, 1987, pp. 36-42).

Assim, as diferentes concepções de democratização do ensino recomendam ações também díspares. A democratização concebida como expansão do acesso à escola prevê a ampliação do ensino ginasial como ação política expressiva do princípio democrático da igualdade do direito à educação. Por outro lado, a democratização entendida como prática

\footnotetext{
18 Cabe lembrar que os Ginásios Vocacionais diferenciavam-se das escolas da rede regular de ensino por gozarem de ampla autonomia pedagógica, administrativa e financeira. Por ocasião da reforma de 1967, essas escolas recusaram-se a participar do exame de admissão simplificado proposto pela Secretaria de Educação. Cf. CURY, Ariam José Ferreira de Castilho. Azanha e a democratização do acesso ao ensino: 1967-1970. Dissertação (Mestrado em Educação) - Faculdade de Educação da Universidade de São Paulo, São Paulo, 2012.
} 
pedagógica parece transformar a experiência igualitária da democracia numa meta pedagógica, isto é, no resultado esperado de um processo de escolarização - ainda que restrito a poucos. De fato, como observa Azanha, a proposta de democratização do ensino dessa pedagogia renovada postula de modo tácito que a democracia nada mais é que a associação de indivíduos com disposições e atitudes democráticas eventualmente desenvolvidas na escola. De acordo com essa pressuposição, "é como se a escola democratizada, formando homens livres, fosse condição para edificar a sociedade democrática - reunião dos homens livres" (AZANHA, 1987, p. 37). Mesmo sem considerar ainda a capacidade de a experiência escolar assegurar a formação de tais requisitos, parece claro que, de acordo com essa interpretação, as relações políticas democráticas devem ser fabricadas por meio de um processo pedagógico. E como em toda fabricação, a produção pedagógica da sociedade democrática deve ser controlada tecnicamente a fim de garantir a "qualidade" do produto final, ainda que isso implicasse à época a negação do acesso imediato à escola à maioria da população. Numa palavra, enquanto a expansão do acesso afirma a igualdade num ato político aqui e agora, a relação pedagógica democratizante a adia para o fim da formação escolar num "futuro incerto" (AZANHA, 1987, p.36) ${ }^{19}$.

Nesses termos, Azanha exclui da aplicação dos conceitos de política, democracia e democratização qualquer associação com metodologias específicas de ensino, sejam elas consequentes ou não na formação de "personalidades democráticas". Tendo em vista que essa associação é usual no discurso pedagógico moderno, talvez seja o caso de insistirmos na clivagem sustentada pelo autor. Azanha recusa a pressuposição, presente na pedagogia renovada dos Vocacionais e de outras instituições de ensino atuais, de que a criação ou o aperfeiçoamento das relações sociais e políticas características da democracia dependam necessariamente de um processo de formação escolar. De acordo com esse ponto de vista, não faz sentido caracterizar uma prática pedagógica como mais ou menos "democrática", isto é, mais ou menos preparatória ao exercício de disposições necessárias à convivência

\footnotetext{
${ }^{19}$ A ideia de fabricação é inspirada em Hannah Arendt. Cf. A condição humana. RJ: Forense, 2014. Para Arendt, a fabricação ou obra é uma das atividades básicas da vita activa do homem. Ela é a atividade criadora dos produtos duráveis que constituem o artificialismo do mundo, como uma mesa ou um livro. A fabricação ou realização de uma obra, de acordo com a autora, possui sempre um "fim", no duplo sentido do termo: a produção tem um término e uma utilidade, isto é, seu produto será um meio utilizado em outra atividade. A obra, assim, distingue-se da ação característica da política, marcada pela liberdade e, portanto, não condicionada por nenhuma finalidade e sem fim previsível. Ver também CARVALHO, José Sérgio Fonseca de. A liberdade educa ou a educação liberta: uma crítica às pedagogias da autonomia à luz do pensamento de Hannah Arendt in Reflexões sobre educação, formação e esfera pública. Porto Alegre: Penso, 2013.
} 
democrática. Na verdade, práticas pedagógicas reconhecidas como democráticas pelas "pedagogias da autonomia" (CARVALHO, 2013) - como, por exemplo, as assembleias estudantis voltadas à livre escolha dos procedimentos ou conteúdos do ensino - são incapazes de reproduzir, no ambiente escolar, os problemas, interesses e conflitos realmente existentes na vida pública democrática. Como lembra Azanha, a "liberdade do aluno" nesse ambiente pedagógico é "dirigida por objetivos educacionais" e "o que pode unir ou desunir as crianças na escola não é a mesma coisa que associa ou separa os homens na situação política”. A democracia na escola, desse modo, não passa de um "faz-de-conta pedagógico". (AZANHA, 1987, p. 40)

Ademais, não há, por princípio, garantias de que certas práticas pedagógicas inspiradas em modos de convivência e deliberação existentes em regimes democráticos sejam capazes de ensinar democracia. Nas palavras de Azanha, a "permissividade" pode também gerar "atitudes conformistas": as crianças, "entregues ao seu próprio governo", facilmente se organizam "em grupos que exigem dos seus membros um estrito conformismo". Nesse caso, o desdobramento pedagógico da introdução de procedimentos supostamente democráticos na escola pode mesmo degenerar no contrário do pretendido. Assim como no fascismo, o conformismo estimulado pela tirania do grupo pode ser uma lição "desastrosa para os espíritos independentes capazes de formar sua própria opinião contra a opinião unânime" (AZANHA, 1987, p. 40).

Em suma, os dois significados do conceito de "democratização" discutidos por Azanha não se referem a um mesmo processo democratizador dos aspectos quantitativo e qualitativo das escolas. Trata-se de dois usos distintos do termo aplicado ao ensino: democratização como expansão política das oportunidades educativas $o u$ democratização como prática pedagógica. No debate sobre o significado da expansão do ensino ginasial, Azanha não hesita em aderir ao programa veiculado pela primeira acepção da ideia de democratização do ensino. O autor é categórico ao afirmar que, por mais variados que pudessem ser os significados então admitidos dos termos democracia e democratização, eles deveriam sempre se referir a uma condição social e política que pressupõe virtualmente a participação igualitária de todos. Sem discutir a validade da pedagogia renovada, experiências como a dos Ginásios Vocacionais, reservadas a uma ínfima parcela do alunado paulista, não poderiam ser legitimamente consideradas democráticas por restringirem suas práticas pedagógicas igualitárias aos privilegiados atendidos por esse tipo de escola. Em outras palavras, para Azanha, a transposição das noções de "democracia" e 
"democratização" para a descrição e orientação das relações pedagógicas representa um "transporte abusivo" de conceitos originalmente políticos para a "sala de aula" (1987, p.40). Desse modo, nas palavras do autor, "a democratização da educação é irrealizável intramuros, na cidadela pedagógica; ela é um processo exterior à escola, que toma a educação como uma variável social e não como simples variável pedagógica” (1987, p.41).

Em consonância com essa perspectiva, Azanha designa o processo de ampliação do acesso ao ginásio na década de 1960 como um processo de verdadeira "democratização" do ensino - ainda que posteriormente admita certos problemas então originados (AZANHA, 1969b; 1987, p.114; 1995, p. 88 e ss.). Não se trata, como sugeriam os críticos dessa política, de "massificação" ou "deterioração" do ensino público. Na verdade, essa avaliação depreciativa é equivocada, pois, aferrando-se a uma concepção elitista da escola pública, baseia-se confusamente em considerações pedagógicas acerca da medida política de expansão do ensino (1995, p.15). Mesmo se admitindo como verdadeira a hipótese da propalada "queda da qualidade" do ensino público decorrente da ampliação das matrículas, ainda assim o processo de abertura das escolas poderia ser descrito, nos termos de Azanha, como uma medida democrática. Isso porque a democratização do ensino tem a ver com uma ação política - a ampliação do acesso à escolarização - que deve ser julgada em sua dignidade própria, e não de acordo com parâmetros técnicos ou pedagógicos. Boa ou ruim, a escola acessível à maioria da população é uma escola democratizada. Tal entendimento é expresso com clareza num documento redigido pelo autor no contexto de abertura do ginásio, em 1969:

\footnotetext{
Já não é mais historicamente possível esperar que a democratização do ensino decorra, como simples processo residual, de um desenvolvimento econômico. Isso já aconteceu na história de outras nações, mas não pode e não deve mais ocorrer. Sobretudo, não deve. Pois é eticamente indefensável o argumento de que, para ficarem mantidas num certo nível para alguns, as oportunidades educativas possam ser sonegadas a uma grande maioria, com os mesmos direitos. (AZANHA, 1987 , p. 85 , grifos nossos)
}

O ponto que mais interessa à presente discussão, contudo, refere-se exatamente ao conteúdo das alegações de falta de qualidade da escola pública provocada por sua democratização, apenas insinuado nas ideias de "massificação" e "deterioração". Azanha responde aos diagnósticos responsáveis por tal "estigmatização" da qualidade do ensino público em mais de uma ocasião (AZANHA, 1995). De modo geral, o autor demonstra que as recriminações ao ensino público baseiam-se na comparação do ensino da escola 
democratizada com o ensino da escola pública existente antes da reforma de 1967. Esses argumentos frequentemente tomavam as taxas de reprovação no ginásio, crescentes após sua democratização, como indicadores fidedignos da perda da qualidade do ensino. De acordo com essa visão, a entrada repentina de alunos antes privados da matrícula pelos rigorosos exames de admissão teria imposto o rebaixamento do nível do ensino, comprovado objetivamente pelo aumento dos índices de retenção. Assim, o "ensino" de "qualidade" característico da "escola pública" se degenerava por causa da presença súbita e inédita de alunos despreparados para as exigências da excelência ginasial ${ }^{20}$.

Azanha recorre a dois argumentos distintos, embora relacionados, para refutar esse tipo de discurso. O primeiro consiste em questionar o valor absoluto da noção de "qualidade" destacando sua referência a um grupo social particular. Sem discutir a veracidade da identificação da queda do nível de ensino indicada nas taxas de reprovação, a ideia de piora da qualidade obviamente adota o ponto de vista unilateral daqueles que puderam frequentar os poucos ginásios públicos existentes antes da democratização do acesso à escola. Em outras palavras,

[...] queda da qualidade do ensino não é algo que se defina em termos abstratos e absolutos. Sendo assim, a queda dessa qualidade é relativa a um nível cultural anterior. Mas que nível? Não, evidentemente, o da grande maioria até então desatendida. Para esta, até mesmo a 'escola aligeirada', de que falava Sampaio Dória, representa um acréscimo, uma elevação. É óbvio, pois, que o rebaixamento da qualidade do ensino, decorrente de sua ampliação, somente ocorre por referência a uma classe social privilegiada[...] (AZANHA, 1987, p. 42)

Nesses termos, os critérios de definição da qualidade do ensino pressupostos na rétorica da queda do nível dissimulam sua referência às expectativas de um grupo social particular. Assim, o novo público escolar, proveniente de outros estratos sociais e historicamente excluído da escolarização de oito anos, é simplesmente abstraído na avaliação do rendimento da nova escola. Os critérios rigorosos e seletivos de avaliação e as correspondentes expectativas próprias de um certo "nível cultural” são, nessa argumentação, erigidos num conceito absoluto e abstrato de "qualidade de ensino".

\footnotetext{
${ }^{20}$ Além dos autores citados acima na nota 16, Azanha não oferece informações precisas a respeito dos autores das críticas à expansão ginasial fundadas na elevação das taxas de reprovação e evasão. Por exemplo, no texto sobre a estigmatização da qualidade do ensino público, Azanha refere-se vagamente à resistência da "imprensa" e dos "professores". Cf. AZANHA, J.M.P., 1995, p. 15. A identificação dos interlocutores de Azanha nesse debate escaparia aos propósitos deste trabalho, que não se propõe a reconstituir a história das ideias educacionais do período. Estamos interessados apenas nos conceitos mobilizados pelos detratores da expansão ginasial e nas respostas formuladas por Azanha. No entanto, o trabalho de Cury, ob cit, refere-se a alguns editoriais de jornais da época interessantes para uma pesquisa de cunho historiográfico sobre o assunto.
} 
A outra réplica de Azanha parte de uma desconfiança das continuidades históricas. Dito de outro modo, o autor questiona a linha evolutiva que sugere a continuidade histórica entre a escola pública formada por alunos previamente selecionados pelos exames de admissão e a escola pública democratizada, necessariamente pressuposta nas comparações entre ambas instituições. Evidentemente, a conclusão a favor da queda da "qualidade" do “ensino" público depende da noção, subjacente às comparações realizadas pelos críticos da democratização, de que a escola democratizada e seu ensino podem ser cotejados com a antiga escola pública. A equiparação, assim, indica a existência de uma mesma entidade, a "escola pública", que apresenta variações na qualidade de seu ensino em diferentes estágios. Nessa avaliação, presume-se que a escola e seu respectivo ensino sejam os mesmos tanto antes como depois da democratização de seu acesso e que a diferença entre os dois momentos seja meramente quantitativa, relacionada ao grau descendente de "qualidade". Nas palavras do autor,

[...] é muito frequente ouvir-se que houve uma deterioração da escola pública a partir de sua maciça expansão nos últimos trinta anos. Essa alegação, aparentemente banal e simples, tem uma pressuposição altamente discutível e provavelmente falsa. Trata-se da ideia de que havia uma instituição social chamada 'escola pública' que cumpria a contento certas funções sociais e que, agora, essa mesma instituição está malogrando com relação a essas mesmas funções. Em resumo: pressupõem-se que as entidades 'escola pública de trinta anos atrás' e 'escola pública de hoje' sejam a mesma instituição, que antes cumpria bem suas funções e agora não. (AZANHA, 2006, p. 97)

Nesses termos, a "escola pública de trinta anos atrás" não pode ser comparada à "escola pública de hoje". O pressuposto que torna possível tal comparação é problemático na medida em que estabelece a identidade institucional entre entidades que são, na verdade, essencialmente distintas. O ensino ministrado na escola atual, uma novidade institucional, não pode tomar por parâmetro o ensino ministrado na escola do passado, de modo que não cabe falar em queda da "qualidade". O significado do ensino numa instituição difere radicalmente do significado do ensino em outra. O ensino da escola democratizada não é uma variação, positiva ou negativa, do ensino ginasial anterior à democratização. Desse modo, a qualidade do ensino não é uma propriedade que possa ser estimada independentemente das situações educacionais em que tem lugar ${ }^{21}$.

\footnotetext{
${ }^{21}$ Não queremos insinuar, nessa e em outras passagens referentes à relativização da noção de qualidade da escola pública democratizada, que Azanha suponha que essa escola não apresente problemas de ensino nem mesmo que ela seja isenta a qualquer crítica. Trata-se simplesmente de pôr em questão a noção abstrata da qualidade, ou seja, sua interpretação como variável absoluta.
} 
Os argumentos que supostamente atestavam a queda da qualidade do ensino, por conseguinte, só podem ser aceitos de plano se essas diferenças essenciais entre os contextos institucionais das duas escolas forem ignoradas. Esse vício descritivo é compreendido por Azanha como exemplar do "abstracionismo pedagógico", conceito que designa a

[...] veleidade de descrever, explicar ou compreender situações educacionais reais desconsiderando as determinações específicas de sua concretude, para ater-se apenas a "princípios" ou "leis" gerais que na sua abrangência abstrata seriam, aparentemente, suficientes para dar conta das situações focalizadas (AZANHA, 2011, p. 42).

O abstracionismo da descrição da queda da qualidade do ensino reside na adoção discutível do conceito de "qualidade do ensino" abstraído do contexto escolar concreto. A noção de qualidade pressuposta nesse tipo de discurso, assim, não leva em consideração as "determinações específicas" da "concretude" da escola democratizada, julgando seu ensino a partir de referenciais arbitrariamente retirados de situações escolares do passado - no caso, o índice de reprovações (AZANHA, 2011, p. 42).

Voltaremos a este assunto no próximo capítulo. Entretanto, não é difícil reconhecer um indício do abstracionismo dessa noção de qualidade do ensino em sua recorrência histórica. Azanha observa que, em diferentes momentos da história da educação brasileira, a qualidade do ensino público primário foi tachada como baixa ou ruim. Não obstante a passagem do tempo, as justificativas dos diagnósticos aventavam problemas semelhantes, tais como a má formação dos professores, a pobreza dos programas, o tradicionalismo do ensino, etc. Comparem-se, por exemplo, as observações de Fernando de Azevedo (1926) e Anísio Teixeira (1962) sobre a escola de primeiro grau:

\footnotetext{
A nossa escola primária não educa, nem do ponto de vista da adaptação moral e higiênica, nem do ponto de vista da adaptação social , isto é, da preparação para a vida e para os deveres cívicos (F. Azevedo, Apud. Azanha, 2011, pp. 44-45)

[...]aceitamos sua [da escola primária] progressiva simplificação: [...] pela redução do currículo a um corpo de noções rudimentares absorvidas por memorização, e a elementaríssima técnica de leitura e de cálculo; [...] pela perda crescente da importância social da escola primária [...] (A. Teixeira, Apud. Azanha, 2011, p. 45)
}

Embora separados por quase 40 anos, os comentários dos educadores concordam quanto à qualidade deplorável do ensino primário. De acordo com Azanha, as duas descrições só podem ser simultaneamente verdadeiras sob duas condições: ou a escola 
primária permaneceu a mesma no intervalo de tempo entre os autores ou os educadores empreenderam análises desatentas à especificidade do ensino primário em seu respectivo momento histórico. Levando-se em conta todas as modificações da sociedade brasileira no período e o próprio crescimento do número de matrículas no ensino primário, parece mais razoável supor que a invariância histórica dos pareceres deva-se à adoção de um critério abstrato de qualidade do ensino primário. De modo semelhante, esse critério abstrato de qualidade presidiria novamente às descrições da "deterioração" do ensino decorrente da expansão do ginásio na década de 1970. Azanha observa com certa ironia que, se todas as afirmações recorrentes da má qualidade do ensino estivessem corretas, o ensino da escola pública não teria decaído, mas permanecido estagnado na ruindade desde sempre (2011, pp. 44-45).

Essa discussão é particularmente relevante para o esclarecimento da noção de autonomia da escola como condição da melhoria do ensino na obra de Azanha. Destacamos anteriormente que o emprego do conceito de autonomia da escola pelo autor, desde sua primeira ocorrência, pretende oferecer referências para a "melhoria do ensino" das escolas, de modo que a autonomia é apresentada como condição necessária para que cada escola aperfeiçoe sua atividade em conformidade com suas particularidades locais. A esta altura, esperamos que tenha se tornado clara a inadequação de tratar tais propostas como prescrições universais de melhoria da qualidade do "ensino", compreendido como uma entidade abstrata que tem lugar nas "escolas" em geral. A breve revisão dos argumentos do autor contra a estigmatização do ensino público demonstra suas objeções às tentativas de compreensão do ensino e da escola em termos gerais, abstraídos das determinações específicas de seu contexto. Por extensão, os escritos sobre autonomia parecem ater-se à interpretação de uma realidade educacional específica: a escola pública cujo acesso havia sido democratizado.

O uso programático do conceito de autonomia da escola, portanto, não representa propriamente a enunciação de uma metodologia, mais ou menos geral, de melhoria das escolas. Fosse este o caso, seria necessário supor que o "ensino" de "boa qualidade" é uma entidade abstrata, sendo reconhecido como tal independentemente das mudanças nas situações educacionais. $\mathrm{O}$ bom ensino, nessas condições, seria algo como uma propriedade ahistórica e inconteste que todas as escolas devessem conquistar por meio da reunião de certas características, entre as quais a autonomia da instituição. A afirmação programática da autonomia por Azanha, no entanto, apresenta simplesmente uma perspectiva singular sobre o significado do ensino e da vida escolar no contexto da escola democratizada 
pertinente à discussão e orientação de suas ações. Nesse sentido, longe de projetar regras de melhoria do ensino fundadas em situações educacionais anteriores, as formulações de Azanha procuram responder à crise do padrão de ensino ginasial acolhendo em suas reflexões a indeterminação de uma novidade institucional.

Em que sentido, então, o uso de autonomia da escola pode ser "indicativo de uma direção na solução dos problemas educacionais"? (AZANHA, 1995, p. 134) Se não há parâmetro absoluto de qualidade do ensino para as diversas situações educacionais, pertencentes a momentos históricos e contextos variados, pode-se pretender que a autonomia de uma escola contribua para a "melhoria" de seu "ensino"? Essas perguntas, no fundo, afloram o problema da interpretação do estatuto programático específico do conceito na obra de Azanha. Ao recusarmos a noção da autonomia como condição de melhoria do ensino em termos abstratos, pretendemos argumentar que a riqueza da ideia, bem como sua força programática, só podem aparecer se prestarmos atenção às relações que mantém com a visão do autor sobre a vida escolar da escola pública democratizada. Em outras palavras, a proposta de autonomia da escola é programática na medida em que sugere uma interpretação específica do significado da nova instituição - de tal modo que, abusando de um jogo de palavras, o uso do termo "escola" esclareça o uso de "autonomia". Destarte, a fim de compreender por que o conceito de autonomia da escola pode ser entendido como uma resposta à crise de um padrão de ensino consagrado pelo ginásio seletivo, passemos à análise dos escritos de Azanha que procuram mostrar o caráter inédito da escola pública democratizada. 


\section{CAPÍTULO 2 - UMA NOVA IMAGEM DA ESCOLA DEMOCRATIZADA}

Eu te ensinarei diferenças. Shakespeare, Rei Lear

- Parece que você conhece melhor as cidades por meio do atlas do que visitando-as pessoalmente - disse o imperador a $\operatorname{Marco}(. .$.

E Polo:

- Viajando percebe-se que as diferenças desaparecem: uma cidade vai se tornando parecida com todas as cidades (...) uma poeira informe invade os continentes. $O$ seu atlas mantém intactas as diferenças: a multiplicidade de qualidades que são como as letras dos nomes.

Italo Calvino, As cidades invisíveis

\subsection{Nota Introdutória}

No capítulo anterior, fizemos breve referência ao abstracionismo atribuído por Azanha às avaliações da qualidade da escola pública democratizada. As análises que indicavam a "queda da qualidade" do ensino por ocasião da expansão das matrículas pressupunham, de acordo com o autor, a comparação entre os índices de reprovação e evasão do antigo ginásio e aqueles exibidos pela escola democratizada. Nessas condições, a constatação da "deterioração" do ensino adotava um critério abstrato de qualidade, isto é, exterior às condições específicas da nova realidade educacional. Não é preciso muito esforço para notar que o abstracionismo imputado por Azanha a essas análises pode ser explicado pela veleidade de converter o desempenho do antigo ginásio, expresso em indicadores como o número de reprovações, em parâmetro inequívoco da "qualidade" do ensino. Uma boa escola, nesses termos, seria aquela que, em qualquer época e lugar, apresentasse bom escore em consagrados indicadores de rendimento.

Embora atraentes, as advertências de Azanha a propósito do abstracionismo desses discursos não são tão óbvias. Afinal, se a qualidade do ensino do antigo ginásio podia ser avaliada em termos de seu desempenho, o que tornaria tal critério ilegítimo ou ao menos insuficiente para a consideração da atividade da nova realidade escolar? Se a escola 
democratizada, a exemplo dos antigos ginásios, é uma instituição dedicada ao "ensino"22, não seria conveniente medir seu rendimento nesse aspecto aparentemente comum? Enfim, em que medida o desempenho do ensino seria um critério de qualidade realmente abstrato na avaliação da nova instituição? Como se vê, retomamos aqui algumas considerações do primeiro capítulo sobre o estigma da má qualidade do ensino público democratizado. No entanto, pretendemos agora pôr em questão os próprios argumentos de Azanha a propósito das diferenças entre o ginásio antes e depois da democratização do seu acesso, diferenças cuja abstração, como vimos, criara condições para a instituição de critérios abstratos de qualidade do ensino.

Como deve ficar claro ao longo de nossa argumentação, a formulação de possíveis respostas às objeções apresentadas acima depende do esclarecimento das distinções entre o antigo ginásio e a escola democratizada traçadas por Azanha. De fato, o reconhecimento do abstracionismo da comparação de desempenho entre as duas instituições só parece plausível se compreendermos as diferenças demarcadas pelo autor em seu propósito de relativizar noções abstratas - associadas por exemplo ao uso de expressões como "ensino" e "escola" - adotadas na descrição da nova realidade educacional. Não se trata exatamente de proceder a um inventário minucioso das características históricas distintivas de uma e outra escola apontadas na obra de Azanha. O que mais nos interessa neste capítulo é chamar a atenção para a ênfase do autor na proposição de coordenadas conceituais para uma descrição densa das novas condições de ensino na escola democratizada, capaz de pôr em questão pressupostos usualmente empregados na consideração de sua atividade.

Para tanto, procuramos estabelecer nesta parte do trabalho - de maneira talvez temerária - uma certa relação entre os argumentos de Azanha em resposta às críticas ao ensino democratizado e os conceitos presentes em suas obras posteriores dedicadas à pesquisa educacional. A julgar por algumas interpretações, a "causa da escola pública" 23 e a

\footnotetext{
${ }^{22}$ Temos consciência das inúmeras dificuldades envolvidas na avaliação do ensino a partir dos resultados obtidos em avaliações da aprendizagem. Afora outras questões propriamente pedagógicas, a própria gramática do uso ordinário do termo "ensino", como nos lembra Scheffler (1974, p. 74-92), mostra que o uso de "ensinar" não pressupõe necessariamente êxito, isto é, a aprendizagem do aluno. É possível que uma mãe ou um pai passem a noite "ensinando" matemática ao filho e que o aluno vá mal na prova do dia seguinte. Nesse caso, não diríamos que seus pais não o tenham "ensinado". Neste trabalho, entretanto, ignoramos essas importantes ressalvas para discutirmos os argumentos que identificavam a "queda da qualidade" do ensino a partir de índices de rendimento associados sobretudo à reprovação.

${ }^{23}$ Cf. os textos de Arlete Marques da Silva e Carlota Boto no sítio do Acervo Azanha, disponíveis, respectivamente,

em http://www3.fe.usp.br/secoes/inst/novo/acervo jmpa/midiateca canal.asp? $\mathrm{cond}=2 \& \mathrm{id}=$ acervojmpa\&pass=43 $\underline{08 \& \text { grupo }=1}$
} 
defesa da democratização do ensino ginasial marcaram integralmente a biografia e a produção intelectual de Azanha. À parte eventuais exageros, essas avaliações podem ser entendidas como indicações de um vínculo interessante entre os conceitos usados pelo autor para se opor à estigmatização da qualidade do ensino público e suas discussões a propósito do abstracionismo pedagógico, da densidade das descrições do cotidiano escolar e outros temas próprios de sua obra tardia sobre a pesquisa educacional. Assim, supondo que os escritos de ocasião e os textos marcadamente teóricos de Azanha esclarecem-se mutuamente, tentaremos argumentar - à revelia da ordem cronológica da obra e quiçá dos desígnios do autor - que aspectos relevantes da escola democratizada, interessantes ao programa de atribuição de autonomia às escolas, puderam ser exibidos por Azanha graças à interdição de descrições abstracionistas da nova realidade escolar tomadas como formas absolutas de avaliar e orientar as práticas escolares.

À primeira vista, considerando a ordem de nossa argumentação até o momento, o percurso ora proposto pode parecer um desvio inesperado - e talvez seja mesmo. No entanto, algumas pistas insinuadas pelo próprio Azanha autorizam tal digressão, entre as quais a recorrência da discussão sobre a "qualidade do ensino" primário no capítulo de Uma ideia de pesquisa educacional (2011) sobre o abstracionismo pedagógico ou ainda as semelhanças entre as descrições caracterizadas como superficiais e a consideração da relação pedagógica como uma interação entre um aluno e um professor abstraídos da vida escolar como mostraremos adiante. No fundo, ao seguir esses indícios espalhados pela obra de Azanha, procuramos simplesmente oferecer ao leitor um quadro de referências mais amplo a partir do qual a "autonomia da escola" possa ser apreciada com maior justiça ao uso programático que nosso autor faz da expressão.

Se nossa interpretação for consistente, ficará claro no fim do capítulo que o exercício de relativização de descrições aparentadas a formas do que Azanha denominou abstracionismo pedagógico relaciona-se ao uso programático da noção de autonomia da escola ao evidenciar aspectos relevantes da nova instituição frequentemente obscurecidos por descrições abstratas de seu "ensino". É nesse ponto que a força propositiva do uso programático de "autonomia da escola" parece inteiramente justificada: a autonomia reivindicada à escola pressupõe a reconsideração dos conceitos abstratos de ensino e de vida escolar. Antes, porém, devemos justificar a qualificação de abstratos atribuída aos conceitos

http://www3.fe.usp.br/secoes/inst/novo/acervo $\mathrm{jmpa} / \mathrm{midiateca}$ canal.asp? cond=2\&id=acervojmpa\&pass $=4308 \&$ grupo $=3$. Acesso em: 20/12/2015. 
usados para constatar a ruindade do "ensino" 24 da escola pública democratizada, apontado já no capítulo anterior.

\subsection{Um conceito abstrato de qualidade do ensino}

Retomemos, então, a pergunta: por que a comparação entre os respectivos desempenhos do antigo ginásio e da escola básica acessível à maioria da população expressos, por exemplo, no número de reprovações ${ }^{25}$ - seria uma medida abstrata da "qualidade do ensino"? À primeira vista, supondo-se a correção técnica desse tipo de mensuração, parece difícil recusar o argumento de que a variação negativa desses índices constitua prova objetiva da deficiência do ensino após a ampliação das matrículas. Podemos até mesmo reconhecer as diferenças irredutíveis entre a escola existente antes e depois da democratização do acesso sem aparentemente invalidar as conclusões dos críticos da iniciativa. Parece possível, nesse sentido, admitir que a nova escola pública atenda a uma população heterogênea e eventualmente não acostumada às rotinas escolares - o que certamente representa um desafio para a manutenção dos índices de desempenho do antigo ginásio - e ainda assim sustentar a credibilidade desses mesmos critérios. Mesmo saudando tais ganhos democráticos da ampliação de vagas, parece não haver motivo para discordar da constatação de que, do ponto de vista do "ensino", a escola pública democratizada é de pior "qualidade". Nesses termos, a comparação pontual do ensino ministrado em ambas as escolas, em que pesem suas inegáveis diferenças, parece legitimamente contrariar as ressalvas de Azanha.

Uma consideração mais atenta de certas noções pressupostas nessa equiparação, entretanto, pode esclarecer por que, nos termos de Azanha, estamos ainda diante de um exercício representativo do abstracionismo pedagógico. Como já referimos, em Uma ideia de pesquisa educacional, esse conceito é usado para qualificar um estilo de investigação

\footnotetext{
${ }^{24}$ Seguimos o autor no uso deste termo. Azanha ora emprega o termo para se referir à relação pedagógica entre professor e alunos, ora dá a entender que o ensino seja uma forma geral de organização do trabalho escolar, como em "padrão do ensino" ginasial, ora o usa para conceituar a atividade do professor, etc. Usamos o termo entre aspas, assim como o termo escola, para enfatizar certos usos discutidos neste capítulo, conforme adiantamos na nota 2 do capítulo 1.

${ }^{25}$ Para os críticos da política de democratização do ensino, o aumento das taxas de reprovação, sobretudo no primeiro ano do ginásio democratizado, constituiria prova objetiva da queda do nível do ensino. Em seus textos, conforme mencionado nas notas 16 e 20 do primeiro capítulo, Azanha não identifica com precisão seus interlocutores. Sobre o assunto, veja-se também a dissertação já citada de CURY.
} 
caracterizado pela tentativa de "descrever, explicar ou compreender situações educacionais reais, desconsiderando as determinações específicas de sua concretude, para ater-se a (...) princípios gerais" (AZANHA, 2011, p. 42). Na ocasião, o abstracionismo era atribuído por Azanha aos diagnósticos que apontavam a má qualidade da "escola brasileira" primária a partir da noção abstrata de "escola" desligada de qualquer contexto social ou histórico. Nessas investigações, nas palavras do autor, "a escola brasileira tem sido estudada como se fora um entidade abstrata, completamente desligada de uma ambiência histórica" (2011, p.45). Assim, essa vertente particular do abstracionismo adota um conceito de "escola brasileira" que "não tem vinculação semântica com a realidade educacional do país" e que é avaliada a partir de um critério de qualidade cujo "fundamento empírico é quase impalpável" (2011, p.53). Segundo Azanha, essas “análises, por não se fundamentarem em cuidadosos e preliminares estudos descritivos, sugerem uma permanência a-histórica da escola, sendo por isso mesmo incapazes de captar as efetivas transformações que ocorreram nas últimas décadas" (AZANHA, 2011, p.45). Com efeito, as alegadas deficiências do ensino primário eram supostamente explicadas nesses estudos por fatores abstratos como a "má formação dos professores" ou a "pobreza do currículo", problemas cujas implicações na "qualidade" do ensino não se encontravam justificadas de maneira consistente por "laboriosas descrições indispensáveis" (AZANHA, 2011, p.53). Como vimos no capítulo anterior, justamente essa indiferença em relação à descrição das condições concretas do ensino da escola primária em diferentes épocas permitia a adoção de veredictos transhistóricos sobre as causas da "ruindade estagnada" do ensino primário da "escola brasileira".

Outra variante do abstracionismo pedagógico criticada por Azanha em Uma ideia de pesquisa educacional é representada pelos estudos que, embora inspirados numa "respeitável perspectiva teórica", a marxiana, resvalariam numa "contrafação" de explicação das práticas escolares a partir de suas relações com os processos sociais e econômicos de um determinado período histórico (AZANHA, 2011, p.51). Nesse caso, a "ambiência histórica" ou, mais precisamente, as condições socioeconômicas de um período não são desprezadas, mas antes convertidas no único fator explicativo da realidade educacional, "abstraído do resto e por isso pura e simplesmente abstrato" (AZANHA, 2011, p. 47). Desse modo, contrariando as advertências do próprio Marx quanto à necessidade de se mostrar nos "fatos" o "elo existente entre a estrutura social e política e a produção [econômica]", essa modalidade de abstracionismo pedagógico isola e confere vida própria a supostas injunções 
dos processos socioeconômicos sobre a realidade educacional, dispensando-se de apresentar, na concretude do real, a efetividade das relações postuladas (2011, p.47). Daí a

[...] obsessiva preocupação em só descrever a escola e explicar os problemas educacionais a partir de hipotéticas relações do processo educativo com outros processos socioeconômicos, [que] conduziu a um arrogante e equivocado descaso pela dinâmica, com um certo grau de autonomia, do conjunto de práticas escolares. Relegadas [tais práticas] à condição de mero e desimportante epifenômeno, nada mais restaria, então, senão enunciar formalmente as hipotéticas relações entre os processos sociais na sociedade capitalista em que vivemos, incluindo nessa enunciação alguns "fatos" corroboradores. (AZANHA, 2011, p. 46)

Esse tipo de descrição da escola, em que pesem suas evidentes diferenças em relação àquele dos partidários da ruindade estagnada do ensino primário, não deixa de ser abstrato apenas por se referir a certa ambiência histórica. Enquanto nas análises a-históricas da escola primária os conceitos usados para descrição da "escola brasileira" não apresentavam "vinculação semântica com a realidade educacional do país" num determinado contexto, os conceitos alegadamente descritivos empregados nos estudos autodenominados materialistas têm virtualmente vinculação com todo e qualquer contexto, uma vez que certas relações formais entre ensino e condições sociais de produção econômica são imputadas a "fatos corroboradores" mobilizados para confirmar sua ocorrência em quaisquer circunstâncias educativas. Todas as evidências empíricas que virtualmente oferecessem um desmentido a tais relações abstratas são simplesmente "deixadas de lado" a fim de que a complexidade do real seja substituída por uma "fantasia verbal” supostamente descritiva das práticas escolares concretas (AZANHA, 2011, p.53).

Entre os exemplos citados por Azanha para ilustrar tal ardil abstracionista, podemos destacar, por sua clareza, a referência ao estudo de uma pesquisadora que, entre outras tentativas de descrição do funcionamento da escola, afirma que "os textos de leitura dos livros didáticos das quatro primeiras séries do Primeiro Grau transmitem uma ideologia, formulada e imposta pela classe dominante à classe dominada, como sendo a única e verdadeira visão do mundo" (AZANHA, 2011, p. 101). Para comprovar a veracidade dessa formulação, a autora foi levada a interpretar as variantes da história de João Felpudo, recorrentes nos livros analisados, como exemplar de um texto que comprovaria o desejo da classe dominante brasileira de humilhar as crianças pobres que "sentem-se sujas (sic), não por ignorarem os hábitos de higiene, mas, principalmente, por falta de recursos" (2011, pp.101-102). O fato de narrativas semelhantes figurarem em outras tradições literárias de 
culturas e épocas diferentes é simplesmente ignorado pela autora para que a dominação simbólica da classe dominante nacional, abstraída como critério explicativo exclusivo, acomodasse-se a certos "fatos corroboradores" (AZANHA, 2011, pp.101-102). Contudo, a explicação apresentada pela autora para a presença dessa história nos livros didáticos dessas escolas, nessa localidade e nessa época, poderia ser generalizada para qualquer formação social capitalista moderna, uma vez que o significado dessa narrativa está dado de antemão na associação abstrata entre a "classe dominante", a "dominação simbólica" e João Felpudo, restando ao pesquisador corroborá-la pela apresentação de supostos "fatos".

Nesses termos, as duas modalidades de abstracionismo denunciadas explicitamente por Azanha em sua obra a respeito da pesquisa educacional assemelham-se no descaso pelo estudo do complexo jogo das práticas escolares existente no cotidiano escolar. Tanto um quanto outro estilo de investigação educacional substituem a compreensão da cotidianidade da ação educativa por descrições abstratas da escola, fundadas ou em critérios abstratos para a definição da ruindade estagnada do ensino ou em referenciais teóricos formais e abstratos que se imprimem de antemão a certos "fatos" ilustrativos da inexorabilidade das relações entre escola e processos socioeconômicos.

O abstracionismo dos críticos do ginásio democratizado a partir da reforma de 1967 parece ser de outro tipo - ou ao menos apresenta elementos distintivos não tratados diretamente por Azanha nessa discussão específica. A constatação da "queda da qualidade" em decorrência da democratização do ginásio fundamenta-se, ao que parece, em dados empíricos "objetivos" fornecidos pelas estatísticas educacionais. A "estagnação na ruindade", familiar às análises da educação básica brasileira, parece desta feita não se tratar de simples impressão, mas de um "fato" baseado em provas concretas. Esse aparentemente é o motivo que nos leva a ver certa coerência no argumento de que, do ponto de vista dos índices objetivos de "ensino", a qualidade do antigo ginásio é indiscutivelmente superior. Pois se os índices que estavam na base da reprovação eram a medida objetiva da qualidade do ensino ginasial, parece forçoso mantê-los nessa posição depois da democratização da escola básica. O talhe abstracionista dessas avaliações, portanto, não pode ser atribuído imediatamente à ausência de fundamentos empíricos correspondentes ao conceito de qualidade aplicado à consideração do desempenho da escola democratizada.

$\mathrm{Na}$ verdade, os problemas dessa espécie de empirismo abstrato empregado na comparação do desempenho das duas escolas não podem ser evidenciados nos supostos "fatos" contabilizados pelas estatísticas educacionais (AZANHA, 2011, p.43). É certo que 
poderíamos justificadamente pôr em dúvida, num gesto semelhante ao de alguns escritos de Azanha, as condições de produção desses "fatos" e estatísticas ${ }^{26}$. Poderíamos, por exemplo, desconfiar da credibilidade dos resultados das avaliações empreendidas pelos professores do ginásio em reação à expansão repentina das matrículas. O fato é que, mesmo confirmadas, essas suspeitas não são capazes de invalidar o critério mesmo de que a elevação dos índices de reprovação constitua prova objetiva da má qualidade do ensino oferecido na escola acessível à maioria da população - tais objeções podem, no máximo, indicar a aplicação equivocada do critério, não sua inadequação. Se, apenas para argumentar, admitíssemos um cenário em que os dados de repetência e evasão fossem obtidos em avaliações escolares consistentes e organizados de maneira tecnicamente perfeita, as conclusões sobre a qualidade do ensino neles fundamentadas ainda seriam tipicamente abstracionistas na visão de Azanha. Arriscamos dizer até que na hipótese absurda de que o ginásio democratizado subitamente conhecesse um choque de gestão capaz de diminuir as taxas de reprovação a zero, a consideração unilateral da qualidade da escola com base em tais índices utópicos continuaria sendo, nos termos de Azanha, o "fundamento empírico" para o coroamento de uma excelência abstrata. Numa palavra, o abstracionismo dessa interpretação não tem a ver com os "fatos" que supostamente descreve.

O ponto essencial é que, ao contrário do que pressupõem os críticos da democratização do ensino, essas descrições da queda da qualidade da escola não são exatamente descrições "objetivas" de "fatos" inscritos nas estatísticas educacionais. Ou, numa formulação talvez mais conveniente, esses fatos só podem ser tomados como tal em razão da aplicação de certas pressuposições na abordagem da vida escolar, de modo que esses dados sejam transformados no fundamento empírico de um conceito determinado de “qualidade do ensino". Esses índices são tomados como expressões de "fatos objetivos" da vida escolar apenas se os conceitos de qualidade e de ensino lhes conferirem o estatuto

\footnotetext{
${ }^{26}$ Pretendemos tratar do assunto no fim deste trabalho, quando discutirmos a "mentalidade" de parte do professorado, que, na opinião de Azanha, não teria compreendido os esforços políticos de democratização do acesso ao ensino. Veja-se, por exemplo, A estigmatização da escola pública (1995) e A repetência como meta política (2006). Como já observamos no primeiro capítulo, a expectativa de manutenção dos índices de reprovação e evasão característicos do período anterior à reforma de 1967 baseia-se na abstração das diferenças entre a antiga população escolar e novo público contemplado com a expansão das matrículas. Nesses termos, a retórica da queda do nível fundada na observação do aumento desses índices dissimula sua referência a expectativas de desempenho próprias das classes que frequentavam o ginásio seletivo. Para quem passou a frequentar a escola apenas após o fim dos exames de admissão, não faz sentido falar em "deterioração" do ensino. Não é nosso propósito retomar aqui esta discussão. Por razões que devem ficar evidentes a seguir, queremos agora discutir a presunção de objetividade da verificação da "queda do nível" a partir de algumas pressuposições ligadas aos conceitos empregados nessa forma de descrição da escola básica democratizada.
} 
paradigmático de provas empíricas do desempenho escolar deteriorado. Esses dados, portanto, não possuem qualquer significado intrínseco; eles adquirem o significado de prova objetiva do rebaixamento da qualidade do ensino apenas se o desempenho da escola, expresso nessas estatísticas, for tomado arbitrariamente como medida de qualidade. Nesses termos, esses índices se convertem em fatos objetivos do fracasso do ensino democratizado de acordo com certos pressupostos relativos ao ensino e à mensuração de sua qualidade.

Tentemos deixar este ponto mais claro. Para isso, talvez seja instrutivo recorrer a uma analogia com as discussões do próprio Azanha sobre a mensuração das "competências" presentes em escritos a respeito do Exame Nacional do Ensino Médio - ENEM (2006, pp. 169-201). Nessas passagens, entre outras ressalvas referentes aos objetivos desse exame nacional, o autor observa que a possibilidade de averiguação do grau de "competência" exibido por um aluno numa determinada atividade escolar envolvendo a escrita ou leitura depende do pressuposto, implicado num certo uso desse conceito, de que o comportamento empírico em questão possa ser descrito e avaliado em termos da manifestação ou ausência de uma faculdade (cognitiva?) conhecida como "competência". Desse ponto de vista, um desempenho mais ou menos excelente numa atividade escolar como escrever ou ler um texto é explicada, no jargão da pedagogia das competências, pela posse e mobilização mais ou menos eficiente da "competência" escritora e leitora (2006, p.170).

Obviamente, os atos de ler e escrever descritos ou explicados nesses termos só podem ser vistos como amostras empíricas da referida competência graças ao uso referencial do conceito que sugere uma determinada faculdade, ou algo que o valha, - enfim, uma "competência" - como matriz dessas práticas escolares. Por exemplo, só podemos dizer que as mais diferentes práticas de escrita e leitura nas variadas disciplinas escolares exibem ou não a "competência escritora e leitora" de um aluno se, por meio dos pressupostos desse uso do conceito, estabelecermos que essas diferentes ocorrências devam corresponder a manifestações de uma mesma entidade psicológica. Nessas explicações, atividades tão díspares como ler um texto de história para encontrar uma informação, ler uma equação matemática, fazer uso da norma culta da língua portuguesa e registrar um experimento científico devem ser vistas como expressões de uma mesma "competência". Nesse sentido específico, o uso do conceito de competência institui os "fatos" que procura descrever ou explicar. Nada no comportamento observável de Joãozinho ao ler ou escrever um texto serve de prova inequívoca da manifestação da "competência leitora e escritora". Esses comportamentos são antes transformados em aparições dessa "competência" quando somos 
levados, por um certo uso desse termo, a postular a existência da atividade de uma faculdade correspondente ao substantivo "competência" para explicar o que Joãozinho faz na aula.

Ora, de maneira não muito diferente, a descrição dos índices de reprovação como prova objetiva do fracasso do ensino democratizado também institui os fatos que alega simplesmente constatar. Nessas descrições, o uso do conceito de "qualidade do ensino" comporta pressuposições que, dentre outras coisas, estabelecem que o ensino oferecido pela escola democratizada deva ser avaliado de acordo com os índices de desempenho da instituição - e, de resto, que esses índices devam ser tomados como comparáveis àqueles apresentados pelo mesmo ensino que tinha lugar nos antigos ginásios. Como no caso das supostas manifestações da "competência", não há nada nos "fatos" descritos pelo conceito de qualidade de ensino que possa contrariar o critério pressuposto na descrição desses mesmos "fatos". Na verdade, esses "fatos" objetivos são instituídos como tal graças a uma gramática $^{27}$ que toma os índices de reprovação como amostras empíricas dos conceitos empregados na avaliação do "ensino" democratizado. Assim, não obstante suas óbvias diferenças, o uso específico dos conceitos de qualidade do ensino e competência estabelecem, de um modo semelhante, a existência dos "fatos" que procuram descrever.

Apesar de longa, a discussão anterior era necessária para enfim ensaiarmos uma resposta à pergunta levantada acima a respeito do abstracionismo notado por Azanha na estranha dedução da qualidade duvidosa do ensino da escola democratizada a partir dos índices de desempenho exibidos pela instituição após a expansão de suas vagas. Essas análises são abstratas não porque deixam de apresentar fundamentos empíricos para as alegações ostensivas da má qualidade do ensino democratizado. Nessa modalidade, o abstracionismo pedagógico pode ser antes definido como resultado do manejo abstrato de conceitos para descrever a nova realidade educacional. Observamos no capítulo anterior que um dos aspectos criticados pelo autor na comparação entre o antigo ginásio e a escola democratizada é a própria pressuposição da existência de uma mesma "qualidade de ensino"

\footnotetext{
${ }^{27}$ A definição de gramática, função gramatical, proposição gramatical em Wittgenstein é complexa demais para os propósitos deste trabalho. Aqui usamos o termo para se referir a um conjunto de regras que são condição de sentido das expressões nessa forma de descrição da vida escolar que associa "índices de rendimento" a "qualidade do ensino". Já no caso da crítica da pedagogia das competências, Azanha aponta a confusão das regras do uso do termo "competência". Ao dizermos que alguém tem "competência" em jogar futebol, não teríamos grandes problemas em nos fazermos entender devido à nossa familiaridade com a gramática cotidiana do uso do termo. A confusão surge quando somos levados, pelo uso dessa palavra como um "termo geral" - a "competência" - , a pensar que ela deva corresponder a algo que os psicólogos irão descobrir. Nesse caso, uma confusão quanto à gramática específica dessa expressão nesse jogo de linguagem leva-nos a perguntas igualmente confusas como "O que é competência"?.Ver A pedagogia das competências e o ENEM, in A formação do professor e outros escritos. São Paulo: Senac, 2006.
} 
correspondente a duas fases de uma mesma instituição, a "escola pública". A essa altura deve estar claro que tal equiparação só é possível porque a novidade do ensino na escola democratizada é obscurecida em favor de descrições que levam exclusivamente em conta o desempenho do "ensino" como medida de sua "qualidade".

O abstracionismo dos críticos da democratização aparece ali quando se postula a existência de uma mesma atividade de ensinar voltada à otimização do rendimento individual dos estudantes tanto em uma como em outra escola. Sob esse aspecto abstrato, as complexas diferenças entre o antigo ginásio e a escola democratizada podem ser atenuadas em favor da conexão conceitual exclusiva do "ensino" ao rendimento positivo ou negativo dos alunos documentado pelas taxas de reprovação. Em outras palavras, a retórica dos críticos da democratização da escola é abstrata porque adota um conceito de ensino e de mensuração de sua qualidade - originado, como veremos, na vida escolar dos antigos ginásios - como critério de descrição da nova situação escolar. De acordo com essa perspectiva, os índices de desempenho apresentados pela nova escola só podiam ser entendidos como indicação objetiva do fracasso qualitativo da medida quantitativa de expansão de vagas. Ao transformar uma forma de vida escolar particular num critério absoluto de avaliação do "ensino", os críticos da reforma de 1967 só conseguiram entrever nessa novidade institucional uma pobre e abstrata "queda de qualidade". Como se lê em uma das inúmeras respostas de Azanha a essa visão abstrata das mudanças ocorridas no "ensino" público,

\begin{abstract}
É preciso ajuizar adequadamente essa diferença [entre o ensino secundário seletivo e o democratizado] para não simplificá-la em termos pedagógicos banais como se ela (a diferença) nada mais fosse do que uma mera questão de queda de nível. $\mathrm{Na}$ verdade, ocorreu algo de mais profundo na própria organização escolar que não chega a ser captado quando se insiste na mera afirmação da queda da qualidade de ensino. (AZANHA, 1995, pp.39-40, grifos nossos)
\end{abstract}

É certo que a mensuração do desempenho dos alunos expresso nas taxas de reprovação poderia eventualmente constituir uma referência para a consideração da atividade da escola democratizada ${ }^{28}$. O problema é que, nessas descrições abstratas da escola, o ensino é tomado unilateralmente sob o aspecto de seu rendimento, de modo que seu contexto institucional específico passa a ser irrelevante ou meramente acidental. Desse

\footnotetext{
${ }^{28}$ Não supomos que o rendimento da escola deva ser abolido como critério para avaliação do ensino ou que a escola democratizada não apresente problemas nesse particular. Aqui, enfatizamos talvez de maneira exagerada o argumento a bem da clareza da discussão.
} 
ponto de vista dogmático, tanto o ginásio quanto a escola democratizada se dedicam a um mesmo "ensino", pressuposto que torna possível o desprezo pelas ligações desse conceito com a complexa trama das vidas escolares distintas de uma e outra instituição. Trata-se, no fundo, de uma descrição do ensino democratizado marcada pelo vício abstracionista de "separar, tomar como autônomos e independentes, aspectos dos objetos (no seu significado amplo) que não são separáveis porque [...] sua separação elimina a própria possibilidade do conhecimento" (AZANHA, 2011, p. 43). No caso, a operação de isolar o "ensino" de uma e outra escola das respectivas vidas escolares a fim de compará-los como se fossem entidades independentes compromete a possibilidade de descrições interessantes da novidade institucional representada pelo ensino democratizado.

\subsection{A discussão de pressuposições supostamente absolutas}

É justamente para se opor a esse tipo de descrição abstrata da nova realidade educacional que Azanha insiste na demarcação de distinções conceituais entre o ensino das escolas existentes antes e depois da democratização do ginásio. Não por acaso, diversos escritos do autor apresentam tentativas de traçar coordenadas conceituais para uma consideração mais atenta das determinações específicas da novidade institucional representada pela escola acessível à maioria da população. Nesses escritos, Azanha procura, de maneira característica, evidenciar e discutir pressuposições tomadas como objetivas e necessárias na descrição da nova vida escolar. A esse respeito, um dos pressupostos discutidos pelo autor refere-se justamente à ideia de permanência de um mesmo "ensino" após a democratização do ginásio iniciada pela reforma de 1967. As ressalvas quanto à generalização de uma forma supostamente necessária de praticar e ver a vida da escola pública aparece numa fórmula recorrente nos escritos de Azanha:

A verdade é que a expansão do ensino ginasial foi de tal monta que tornou inviável, daqui para diante, a permanência de um padrão de ensino concebido para uma parcela da população intelectual ou economicamente privilegiada (1987, p. 97, grifos nossos)

[...] a extraordinária expansão das oportunidades educativas no ensino ginasial tornou inviável a continuidade de um padrão de ensino que, em sua origem histórica, estava voltado à formação de uma elite intelectual. Daí - de sua origem, e somente daí - decorria a validade das exigências intelectuais que o faziam descontínuo com relação ao ensino primário (1987, p. 85, grifos nossos) 
Embora flagrante nessa e em outras passagens atinentes aos significado do ensino na escola democratizada, o empenho de Azanha em mostrar a natureza relativa - não necessária - de certos conceitos usados para descrever as práticas da escola democratizada não é de modo algum exclusivo de sua querela com os detratores da democratização do ensino ginasial. Notamos esforços semelhantes não apenas em escritos a respeito do ensino e da mensuração da sua qualidade, como também naqueles dedicados às noções de método de ensino e à formação de professores, todos pertinentes às discussões sobre a autonomia da escola, como tentaremos indicar oportunamente.

Esse estilo de investigação educacional, na verdade, é apresentado em linhas gerais pelo autor em A questão dos pressupostos no discurso pedagógico (AZANHA, 1987, pp. 13-24). No texto, Azanha refere-se a uma "linha de investigação" eventualmente interessante para a pesquisa educacional, voltada à explicitação e discussão de "pressuposições" do "discurso pedagógico", entendido como o conjunto de "propostas relativas à organização da ação educativa". Uma pressuposição de uma sentença do discurso pedagógico, na definição de Max Black invocada por Azanha, é uma "comunicação implícita" implicada na "comunicação explícita" que constitui a sentença ou proposição. Em outras palavras, uma pressuposição é um "compromisso tácito", um "pressuposto inadvertido" imbricado no uso dos enunciados pedagógicos, cuja explicitação e análise, segundo Azanha, poderiam ser interessantes para o campo educacional (AZANHA, 1987, pp. 15-18).

A conveniência desse estilo de investigação é justificada pelo autor pela possibilidade de aflorar e discutir compromissos assumidos apenas tacitamente nas variadas propostas relativas à ação educativa. A consideração explícita das pressuposições representa, assim, a oportunidade de pôr em questão compromissos implícitos "de natureza científica, filosófica, etc.” das proposições pedagógicas. Esse expediente é interpretado como uma ressalva sadia à adesão irrefletida e dogmática a pressupostos discutíveis. Nas palavras de Azanha:

Esse tipo de investigação poderia explicitar as pressuposições [...] com as quais o conjunto de propostas educacionais está tacitamente comprometido. E o resultado poderia ser de interesse não apenas teórico como também prático, principalmente quando o comprometimento ocorresse de modo a tomar como absolutas [...] pressuposições que fossem essencialmente relativas, isto é, como não questionado nem questionável aquilo que é questionável e deve ser permanentemente questionado. (AZANHA, 1987, p. 18, grifos nossos) 
Nesses termos, a investigação das pressuposições do discurso pedagógico pode mostrar e esclarecer a relatividade de compromissos eventualmente tomados como absolutos, necessários, inquestionáveis. A distinção entre pressupostos absolutos e relativos é emprestada por Azanha de R.G. Collingwood (COLLINGWOOD, 1948, pp. 21-33). Para esse autor, tal como interpretado por Azanha, a distinção refere-se justamente à diferença entre as pressuposições cujo valor de verdade depende de verificação - caso das pressuposições relativas - e aquelas - as absolutas - não passíveis de verificação, que constituem, entretanto, "condições necessárias para que alguma coisa possa ser afirmada ou feita" (AZANHA, 1987, p. 17). Desse modo, as pressuposições relativas e absolutas são de natureza distinta: enquanto as primeiras são contingentes, podendo ser descartadas sem prejuízo para a atividade de um educador, as segundas são condições necessárias ao sentido mesmo da atividade do educador e das proposições relativas à ação educativa.

O exemplo oferecido pelo próprio Collingwood para ilustrar a diferença entre os dois tipos de pressuposição conta a história de um paciente que deseja saber de um médico patologista a causa da doença que o acometeu. A resposta do médico, cuja pressuposição é relativa, indica a existência de um agente causador da doença a partir de resultados passíveis de verificação - obtidos numa determinada pesquisa clássica sobre o assunto. Se, insatisfeito com a explicação, o paciente insistisse em conhecer a justificativa do médico para a pressuposição absoluta, exibida na sua resposta, de que toda doença tem uma causa, o enfermo deveria se surpreender com uma pseudorresposta:

Isto é algo que nós assumimos [take for granted] no meu trabalho. Não o questionamos. Não tentamos verificá-lo. Não se trata de algo que alguém tenha descoberto, como os micróbios ou a circulação sanguínea. É algo que nós simplesmente tomamos por certo [take for granted] (COLLINGWOOD, 1948, p. 31, tradução nossa)

A justificativa do médico, nesse caso, não é verdadeiramente uma resposta, mas o simples reconhecimento do caráter absoluto da pressuposição de causalidade necessária às pesquisas e ao tratamento das doenças ${ }^{29}$. O princípio de que toda doença tem uma ou mais causas é condição para que se façam estudos e se prescrevam terapias na medicina, embora

\footnotetext{
${ }^{29}$ É importante observar que uma proposição absoluta não corresponde a uma verdade absoluta. Como escreve Azanha em outra oportunidade, trata-se de "algo cuja admissão é indispensável numa determinada situação" (grifos nossos), como, por exemplo, a pressuposição de determinadas ciências de que "não obstante a individualidade irredutível" de certos fenômenos naturais, é necessário classificá-los como "pertencentes à mesma categoria" devido ao "alto grau de semelhança" que apresentam em certos aspectos e para determinados propósitos. Ver Uma ideia de pesquisa educacional, p. 85 e nota 21.
} 
não seja uma pressuposição passível de verificação ou discussão. Em educação, esse caráter necessário pode ser atribuído à pressuposição, inerente à atividade do ensino, segundo a qual o ser humano é modificável e capaz de aprender determinados conhecimentos e habilidades. Segundo Azanha, essa pressuposição é absoluta e necessária a qualquer esforço de ensino ou a qualquer proposta pedagógica sobre a ação educativa. Só ensinamos ou elaboramos reflexões sobre a atividade de ensinar na condição de educadores porque supomos que os alunos, em diferentes graus e de maneiras diversas, sejam afetados pela atividade de ensinar. Na hipótese contrária, isto é, a de que o ser humano não é modificável - sendo, por exemplo, mero resultado do determinismo genético ou sociológico -, a atividade do ensino e as afirmações sobre ela seriam desprovidas de sentido. Não é possível continuar ensinando ou formulando recomendações sobre o ensino sem admitir que os alunos sejam educáveis (AZANHA, 1987, p. 17).

De resto, boa parte das pressuposições aceitas como absolutas e necessárias na descrição da vida escolar e nas propostas educativas são, na verdade, relativas e, portanto, sujeitas à discussão. Essa constatação é particularmente importante na consideração das afirmações a respeito da escola democratizada. Na verdade, os diagnósticos abstratos de ruindade do ensino discutidos acima fundamentam-se, segundo Azanha, em noções discutíveis a respeito do ensino e da vida escolar no geral. No mais das vezes, essas descrições tomam como absolutas certas pressuposições ligadas aos conceitos usualmente empregados na consideração da vida escolar do ginásio seletivo existente antes da maciça expansão de vagas iniciada pela reforma de 1967. Assim, não obstante a inviabilidade de tal padrão de ensino, é como se certos conceitos correlatos a essa forma específica de compreender e praticar a vida escolar fossem abstraídos de seu contexto original e se impusessem com força de necessidade à descrição da vida da escola democratizada.

Esse é justamente o caso da ideia da existência de um único ensino avaliado sob o aspecto de seu desempenho - ou por uma certa expectativa abstrata de desempenho -, concepção que Azanha caracteriza acertadamente como fabril. Em Cultura escolar brasileira (AZANHA, 1995, pp. 67-78), o autor, em seu estilo característico, discute os pressupostos das avaliações a respeito da "crise educacional" a fim de mostrar sua relatividade patente no compromisso com um uso particular do conceito de escola e de ensino: 
Nossa ideia de escola tem sido, muitas vezes, excessivamente simplificada. Isso se revela, por exemplo, na própria noção de crise educacional que circula amplamente. É comum apontar-se como evidências da crise alguns resultados escolares como a reprovação e a evasão maciças no $1^{\circ}$ grau [...]. Se realmente esses 'fatos' são evidências da crise, a nossa concepção da escola é, inegavelmente, fabril, taylorista, porque apenas leva em conta os 'resultados' da empresa escolar. Mas, indiscutivelmente, essa visão é muito parcial e muito simplista porque se atém aos 'resultados' da instituição escolar. Ora, [...] esses resultados não tem a objetividade que se pretende, isto é, eles são simples correlatos das maneiras como a vida escolar é praticada [...] os resultados que pinçamos dela são ficções destituídas de qualquer significado empírico interessante (1995, p.73-74, grifos nossos)

Nesses termos, as descrições que "pinçavam" os resultados da "empresa escolar" para comprovar a deterioração do ensino democratizado realizavam a operação conceitual de abstrair os resultados do ensino das maneiras de praticar e compreender a "vida escolar", dotando-os de uma validade supostamente objetiva e absoluta. Tudo se passa como se o "ensino" do antigo ginásio, organizado para atender à parcela da população escolar que exibisse o desempenho acadêmico esperado, devesse necessariamente seguir como paradigma da consideração e orientação do ensino democratizado, apesar da eliminação do rigor seletivo no acesso ao ensino secundário. Ao apontar a "crise" expressa de modo "objetivo" nas taxas de evasão e reprovação, essa concepção fabril da escola democratizada sugere que o "ensino" antes e depois da democratização da escola devem ser os mesmos e que seus resultados devem ser comparáveis.

No entanto, a relatividade dessa "visão abstrata e exterior da escola" é facilmente reconhecida se, nas palavras de Azanha, fizermos "incidir o esforço de descrição nos pontos de interesse" (1995, p. 71 e 74). No caso em questão, a discussão do uso do conceito de "aluno reprovado" como índice aparentemente objetivo do desempenho da escola mostra que, diferentemente do que os críticos da democratização supunham, a queda da qualidade do ensino não é um "fato". Melhor dizendo, a queda da qualidade do ensino só é um "fato" numa forma de praticar a vida escolar contingente e arbitrária, na qual o ensino deve ser avaliado pelo desempenho dos alunos e pelo número de reprovados:

Que é o "aluno reprovado"? Essa entidade (cuja presença maciça nas estatísticas constitui evidência da crise escolar) é fruto de práticas escolares cuja formação, transformação e correlatos podem passar despercebidos. 'Ser reprovado' não é a mesma coisa que 'ter oito anos'. Contudo, se tivéssemos que explicar a um marciano o que significa 'ter oito anos', recorreríamos à descrição de como esse estado é fruto de sucessivos estados anteriores e de determinados correlatos sem os quais 'ter oito anos' seria uma expressão vazia. Sem fazer algo semelhante, como atribuir significado à expressão 'ser reprovado'? O predicado 'ser 
reprovado' não existe a não ser pelas práticas que o produziram (AZANHA, 1995, p. 71-72)

O que Azanha parece pôr em questão no uso do conceito de aluno reprovado não são exatamente as causas didáticas, administrativas ou de outra natureza que teriam como efeito o fato da reprovação, responsável pela suposta queda da qualidade do ensino. As observações do autor não nos parecem recomendações de identificação e correção das práticas concretas de ensino da escola de modo a evitar o aumento do número de alunos reprovados. O que Azanha pretende discutir ao olhar a reprovação como que do ponto de vista de um marciano é o valor absoluto dessa prática e de seu conceito correlato como critério para a avaliação da qualidade de qualquer ensino. Dito de outro modo, Azanha aponta a contingência de considerar o ensino sob o aspecto exclusivo de seu rendimento expresso nos índices de reprovação. Esse tipo de descrição é abstrata porque, apesar de seus supostos fundamentos empíricos, incorre no erro de isolar os resultados de desempenho do ensino de suas ligações conceituais com uma forma particular de organizar a vida escolar originada no ginásio existente antes da expansão da escola básica.

Ao assinalar as ligações entre a noção de "ser reprovado" e determinados conceitos correlatos, Azanha chama nossa atenção para o fato de que o sentido da expressão "ser reprovado" depende de um conjunto de outras noções pressupostas nessa descrição da vida escolar. Essa expressão só ganha significado se usada em referência a uma gramática escolar específica, consagrada pelo ginásio seletivo. A analogia com a contagem da idade sugerida por Azanha é particularmente esclarecedora. A elucidação da expressão "ter oito anos", no contexto apontado, pressupõe a compreensão de que "ano" designa um intervalo de tempo usado para registrar as fases da vida de uma pessoa, que os anos são contados regularmente, que a prática de contagem desses intervalos regulares de tempo estabelece a "idade" de uma pessoa em nossa forma de vida, etc. De maneira semelhante, "ser reprovado" é uma afirmação que apenas faz sentido se admitirmos que a "reprovação" é resultado da avaliação escolar que define a inaptidão de determinado aluno ao prosseguimento dos estudos em razão da carência de conhecimentos e habilidades preliminares, que o critério para a retenção é dado pelo desempenho do aluno medido numa determinada avaliação, realizada por uma escola e um conjunto específico de professores, que a seleção do aluno é necessária para a definição dos ocupantes das vagas disponíveis nos anos escolares subsequentes, etc. "Ser reprovado", portanto, não é uma expressão que simplesmente expõe um índice objetivo 
válido para a descrição de qualquer ensino. Trata-se antes de um conceito dependente de uma forma relativa, entre outras possíveis, de praticar e entender a vida escolar.

Embora a perspectiva do marciano pudesse oferecer um ponto de observação conveniente à relativização da suposta necessidade da associação entre qualidade de ensino e os índices de desempenho da escola democratizada, Azanha não precisa se deslocar no espaço para mostrar a arbitrariedade dessa forma de praticar e descrever a vida escolar. $\mathrm{O}$ autor simplesmente delimita a validade dessa gramática ao ensino ginasial existente até a reforma de 1967, demarcando suas diferenças em relação à novidade institucional representada pela escola básica democratizada. Esse esforço de acentuar dissemelhanças significativas entre as duas instituições no lugar de encará-las como detalhes acidentais da história de um mesmo "ensino" oferecido pela "escola brasileira" parece uma tentativa de indicar outras possibilidades de descrição da vida da escola democratizada mais interessantes às determinações específicas da nova realidade educacional.

Entretanto, essas dissemelhanças significativas da escola democratizada não aparecem espontaneamente em novos fatos, como a diversidade da população que passa a ocupar os bancos escolares. Pois, como sugerimos alhures, é bem possível que a expansão da população escolar seja considerada simplesmente como o aspecto quantitativo da democratização de um mesmo padrão de ensino anterior - decadente, do ponto de vista qualitativo. Dessa perspectiva, os novos fatos escolares seriam descritos abstratamente como simples variação quantitativa de um conceito geral de ensino que não apresentam solução de continuidade em relação ao ginásio seletivo.

Nessas condições, a indicação de uma nova imagem da escola depende da revisão dos pressupostos associados ao uso de conceitos como o de escola, ensino e qualidade de ensino. Ela não depende necessariamente da descoberta de novos "fatos", mas antes de uma perspectiva teórica capaz de acentuar elementos distintivos importantes na descrição das novas condições de ensino. Trata-se, portanto, de uma tarefa de explicitação e discussão de conceitos interessantes à descrição de aspectos frequentemente obscurecidos pelas abordagens abstratas da escola democratizada, acossadas que eram pelo estigma da ruindade alegadamente objetiva do ensino disponível à maioria da população. Esse estilo de investigação pode ser observado em variados escritos de Azanha, com familiaridades e diferenças entre si. Gostaríamos, entretanto, de descrevê-lo à semelhança de um exercício de indicação de conceitos pertinentes a uma descrição densa da escola democratizada. Oportunamente, tentaremos mostrar que esses conceitos usados pelo autor para sugerir 
outras formas de ver a nova realidade educacional aparecem implicados em seu uso programático da "autonomia da escola".

\subsection{Uma descrição densa da escola democratizada}

O conceito de descrição densa (thick description) é apresentado por Azanha em sua obra Uma ideia de pesquisa educacional. Segundo sua interpretação de Ryle ${ }^{30}$, essa classificação engloba as descrições realizadas na prática científica e mesmo em atividades cotidianas capazes de mostrar "diferenças significativas" entre objetos aparentemente semelhantes (AZANHA, 2011 p.158). Desse modo, essa categoria de descrições opõe-se às descrições "superficiais" (thin descriptions), isto é, aquelas que não captam distinções importantes entre objetos parecidos. Cético quanto à existência de um método científico geral capaz de garantir o êxito de qualquer pesquisa, Azanha reconhece na descrição densa uma forma de conceituar as operações realizadas por cientistas quando, de maneira essencialmente criativa, discernem elementos significativos nos respectivos objetos de estudo. No contexto de Uma ideia de pesquisa educacional, o conceito de Ryle é invocado como emblemático do ponto de vista teórico necessário à pesquisa educacional empenhada em "vencer a opacidade" do cotidiano escolar e distinguir, na pletora de acontecimentos repetitivos e banais do dia-a-dia, elementos significativos reveladores de uma "cotidianidade", isto é, de uma totalidade social e histórica inscrita no cotidiano (AZANHA, 2011, p. 122 e 165).

Não obstante tal uso tópico do conceito por Azanha em sua discussão de assuntos pertinentes à pesquisa educacional, reconhecemos exercícios semelhantes a uma indicação de coordenadas conceituais pertinentes à descrição densa da vida escolar na revisão empreendida pelo autor de conceitos usualmente empregados em descrições abstratas da escola democratizada, a exemplo da noção de "ensino" pressuposta ou mesmo proposta em programas de formação de professores e, obviamente, nos ajuizamentos sobre a qualidade do ensino democratizado. Evidentemente, esse tipo de descrição é interessante ao propósito de Azanha de relativizar certos pressupostos e conceitos abstratos aplicados na consideração

\footnotetext{
${ }^{30}$ Cf., por exemplo, RYLE, G. The thinking of thoughts - What is Le Penseur doing? Collected Essays, Londres, Hutchinson, $1971 . \quad$ Disponível em http://www.compilerpress.ca/Competitiveness/Anno/Anno\%20Ryle\%20Thinking\%20of\%20Thoughts\%20U SASK\% 201968.htm. Acessado em 08/11/2015
} 
da nova escola e responsáveis pelo obscurecimento de diferenças significativas dessa novidade institucional. Entretanto, antes de apresentar o que a nosso ver assemelha-se a uma tentativa de descrição densa do ensino democratizado, parece conveniente esclarecer o significado dessa categoria de descrições e sua ligação com os esforços de relativização de conceitos acerca da escola democratizada atribuídos ao nosso autor até aqui.

$\mathrm{Na}$ acepção de Ryle, uma descrição densa, sempre de acordo com a interpretação de Azanha, não tem a ver necessariamente com a descoberta de fatos empíricos decisivos na diferenciação de dois objetos em sentido amplo. Uma descrição não é mais densa por apresentar mais fatos ou detalhes a respeito dos objetos em questão, como se uma descrição densa fosse sempre mais completa ou pormenorizada que uma descrição superficial. A densidade de uma descrição, na verdade, não tem nada a ver com a quantidade de fatos que descreve. Para deixar claro o equívoco dessa suposição, Azanha recorre ao seguinte exemplo:

\begin{abstract}
Imaginemos que dispomos de duas descrições de aspectos físicos de uma mesma pessoa. A descrição A contém informações sobre sua estatura, peso e idade. A descrição $B$, além dessas informações, contém outras sobre medidas do abdômen e do tórax. De um ponto de vista abstrato, pode-se dizer que a descrição B é mais completa porque contém mais informações. Mas, sem que se saiba qual é o propósito que motivou a feitura das descrições, é difícil avaliar a relevância de "ser mais completa" no caso considerado. Seguramente, esse exemplo, por ser abstrato, não ilustra nenhuma diferença de densidade entre as descrições. Diferenças que não têm significado para um observador não são, para ele, diferenças. (AZANHA, 2011, p. 159)
\end{abstract}

Se uma descrição densa, nas palavras de Azanha, logra estabelecer diferenças significativas entre objetos, uma descrição cuja maior ou menor quantidade de informações não faz diferença para o observador não pode ser mais ou menos densa. Tampouco a densidade de uma descrição depende necessariamente de sua maior ou menor objetividade e rigor na consideração de um objeto. Azanha propõe outro exemplo para afastar a associação imediata entre a objetividade, em abstrato, e a densidade de uma descrição:

Uma criança que vai tomar banho põe a mão na água e diz que está muito quente
(descrição A). Sua mãe usa o termômetro e diz que a temperatura é de $37^{\circ}$
(descrição B). Aqui não seria apropriado dizer que uma descrição é mais completa
do que a outra, porque ambas abrangem um único e mesmo aspecto do objeto. Há
outra diferença entre elas Talvez algum pesquisador se apressasse em dizer que o
menino faz uma descrição imprecisa, ambígua, qualitativa; enquanto a descrição
feita pela mãe é precisa porque quantitativa. Qual delas é preferível? Um partidário
das hard sciences diria talvez que a B, por ser mais precisa. Mas e se a precisão
for irrelevante na situação? Na verdade, as descrições A e B não refletem nenhuma 
diferença com relação ao objeto, apenas descrevem a mesma coisa com expressões diferentes. [...]

Não se pode concluir que, com relação a um dado objeto, descrições fenomênicas sejam sempre superficiais e que descrições não fenomênicas sejam sempre densas. (AZANHA, 2011, pp. 159-160)

Nesses termos, uma descrição não é mais densa por penetrar as aparências e atingir a suposta essência dos fenômenos por meio de notações mais objetivas. Em abstrato, a maior precisão da descrição não corresponde necessariamente a sua capacidade de mostrar distinções importantes nos objetos em tela.

Diante dessas ressalvas, o que seria algo como uma descrição densa? O que se parece, afinal, com uma descrição capaz de perceber diferenças significativas nos objetos descritos? Azanha, seguindo o estilo de Ryle, não oferece uma definição ostensiva do conceito. Na interpretação de Azanha, o conceito é simplesmente usado num exemplo bastante esclarecedor emprestado do filósofo de Oxford:

\footnotetext{
Dois meninos contraem, rápida e regularmente, as pálpebras de seus olhos direitos. Num dos meninos, isso é apenas uma involuntária contração nervosa, mas o outro está piscando conspiratoriamente para um cúmplice. Num baixo e superficial nível de descrição, pode-se dizer que as duas contrações de pálpebras são exatamente iguais. Se as duas faces fossem filmadas, talvez não se pudesse dizer em qual delas houve uma contração nervosa e em qual houve uma piscada. Mas há uma imensa e não fotografável diferença entre um tique nervoso e uma piscadela. Para piscar [com êxito], é preciso combinar o sinal com alguém sem conhecimento de outros e também que haja uma mensagem já definida segundo um código já compreendido. [...] A piscada seria um insucesso se o receptor visado não conhecesse o código, ou o tivesse esquecido, ou o interpretasse mal [...]. Uma simples contração nervosa, de outra parte, não é um êxito ou um insucesso, ela não visa um receptor, nem pretende ocultar-se de alguém, ela não veicula uma mensagem. (RYLE Apud. AZANHA, 2011, p. 158)
}

De acordo com o exemplo, uma descrição superficial das piscadelas indicaria que "as duas contrações de pálpebras são exatamente iguais". Inversamente, uma descrição densa das mesmas ações destacaria diferenças significativas capazes de levar o observador a discernir a contração nervosa involuntária da transmissão codificada de uma mensagem. Essas diferenças decisivas, contudo, não são observadas simplesmente pelo acréscimo de mais informações a respeito do movimento muscular da pálpebra nem mesmo pelo inventário minucioso das incontáveis operações fisiológicas envolvidas nesse movimento de acordo com uma linguagem mais rigorosa. Na verdade, as diferenças significativas entre o tique e a piscadela intencional não se encontram dadas imediatamente nos movimentos de 
pálpebra que são objeto das descrições ${ }^{31}$. Apesar de "imensa", a diferença entre eles não é "fotografável”, isto é, não é uma propriedade localizável nas contrações das pálpebras dos dois meninos. Pelo contrário, a focalização exclusiva nas próprias piscadelas é que induz erroneamente uma descrição superficial à conclusão de que se trata de dois fenômenos "exatamente iguais". Essa interpretação corresponde ao entendimento de Azanha de que a superficialidade de uma descrição pode ser imputada ao "hábito de imaginar que descrever um objeto é atribuir a ele certas propriedades ou qualidades como se ele fosse uma entidade autônoma, quando, na verdade, não o é” (AZANHA, 2011, p. 160).

De fato, as dissemelhanças decisivas entre o tique e o gesto comunicativo só podem ser afloradas por meio da descrição dos respectivos comportamentos segundo critérios inapreensíveis a partir de propriedades das piscadas em si. A demarcação de diferenças significativas depende antes da observação perspicaz dos critérios capazes de separar o caso em que se aplica o termo "tique nervoso" daquele que pode ser adequado à aplicação da noção de "piscadela conspiratória". Embora o próprio Azanha não se estenda nessa discussão, os comentários transcritos de Ryle no exemplo são suficientes para indicar que dispomos de uma "carga conceitual" corrente nas regras de uso da linguagem cotidiana que conta com meios de apresentação observáveis da diferença entre as noções de "contração nervosa involuntária" e "piscadela como forma de transmissão de uma mensagem" (AZANHA, 2011, p. 162). Por exemplo, para descrevermos o gesto como uma "piscada conspiratória”, provavelmente observaremos se o garoto em questão visa algum receptor, se sua piscada apresenta certa regularidade indicativa da observação de certo código previamente acordado, se o mensageiro apresenta movimentos de corpo sugestivos de tentativas de ocultar a piscadela, etc. Todos esses movimentos sutis, relacionados de algum modo à carga conceitual disponível para nossas descrições cotidianas de gestos deliberados, ajudam um observador arguto a discernir a intenção do garoto de transmitir uma mensagem em seu movimento de pálpebras. Em todo caso, a descrição densa desse comportamento empírico depende de um uso inteligente de critérios disponíveis numa carga conceitual que não é dada na observação fotográfica de propriedades supostamente intrínsecas ao próprio movimento de pálpebras. Se contrair rapidamente a pálpebra não fosse uma forma de linguagem usada e reconhecida como tal em nossos modos de expressão, a questão de saber se a contração de pálpebra é só um movimento muscular involuntário ou algo mais não faria

\footnotetext{
${ }^{31}$ A respeito da ideia de que a observação para fins cognitivos sempre depende de certos conceitos, ver também HANSON, N. R. Observação e interpretação. In Filosofia da Ciência. Org. Morgenbesser, São Paulo, s/d.
} 
sentido. Sua distinção numa descrição densa é relevante quando o movimento de pálpebra, mesmo sendo apenas uma contração de pálpebra, é também muito mais que isso ${ }^{32}$.

Nesses termos, uma descrição densa é resultado da destreza no uso de conceitos capazes de diferenciar as propriedades que um fenômeno assume em determinadas condições que o diferenciam de sua ocorrência em outras circunstâncias. Trata-se justamente de afastar o hábito superficial de descrever determinado fenômeno enumerando supostas propriedades essenciais e abstratas, sem considerar as regras que instituem seu significado específico numa situação determinada. Como significativamente reza a frase de Marx transcrita por Azanha como epígrafe de seu capítulo sobre o abstracionismo pedagógico em Uma ideia de pesquisa educacional, "um negro é um negro. Só em determinadas circunstâncias ele se converte num escravo" (AZANHA, 2011,p. 41). Ou ainda, poderíamos dizer, com Ryle, que "uma Dama de Copas é uma Dama de Copas" e que apenas em "determinadas circunstâncias" ela se converte no "último trunfo que resta para sair" no jogo:

\begin{abstract}
As cartas com as quais se joga pôquer são as mesmas do jogo de bridge ou são diferentes? Certamente são as mesmas. Mas as propriedades das cartas que o jogador de pôquer leva em conta (ou não) são as mesmas que o jogador de bridge leva em conta (ou não)? Esses jogadores dão descrições diferentes e até mesmo conflitivas? Não é fácil responder a isto. Porque enquanto ambos tomam em consideração que uma determinada carta é a Dama de Copas, um deles sabe (ou talvez não saiba) que é o último trunfo que resta para sair, enquanto o outro nem tem essa expressão no seu vocabulário de pôquer. [...] A questão de saber se a Dama de Copas é, num certo momento, um trunfo ou não depende da questão prévia de saber se quatro pessoas estão jogando bridge com o baralho que contém essa carta, e o que faz com que Copas ou qualquer outro naipe sejam trunfos não se acha oculto ou latente por trás das brilhantes faces das cartas, mas simplesmente depende da natureza geral do jogo de bridge. (RYLE, apud. AZANHA, 2011, pp. 160-161)
\end{abstract}

O exemplo dos jogos de cartas é bastante elucidativo da dependência das propriedades assumidas pelos objetos da descrição (as cartas, no caso) em relação às regras pressupostas na prática do jogo (a "natureza geral do jogo"). Assim, uma mesma carta pode exibir propriedades distintas de acordo com as regras válidas no jogo, em determinado momento da partida, etc. De maneira análoga, o pestanejar dos meninos pode significar coisas diferentes dependendo das regras do jogo da piscadela, isto é, se se trata de um tique

\footnotetext{
${ }^{32}$ No texto referido, Ryle, para refutar a interpretação de que a diferença significativa da descrição densa seja uma propriedade ou uma atividade adicional localizável no próprio objeto da descrição, evoca um exemplo bastante esclarecedor. Um diplomata que assina seu nome num papel que põe fim a uma guerra, diz ele, não faz duas coisas: escrever seu nome e pôr fim a uma guerra. Ele antes põe fim a uma guerra escrevendo seu nome num tratado.
} 
involuntário ou da comunicação criptografada de uma mensagem previamente combinada com um receptor. Presumivelmente, as regras capazes de lançar luz sobre as propriedades de uma carta num determinado jogo podem ser mais facilmente conhecidas do que aquelas requeridas para uma descrição satisfatória de uma piscadela. Isso porque, em caso de dúvida, podemos consultar algo como um manual de regras explícitas do jogo, recurso não disponível no episódio das piscadas e em muitas situações em que lidamos com a carga conceitual de uma teoria ou com a trama conceitual do cotidiano, nas quais "temos que ler na própria conduta os códigos não escritos dessa conduta e não há também obras de referência que nos digam se lemos mal" (AZANHA, 2011, p. 162). Daí a insistência de Azanha, em Uma ideia de pesquisa educacional, na inexistência de um método científico explícito capaz de orientar, com êxito, a pesquisa educacional do cotidiano escolar. Diferentemente de um jogo com regras previamente formuladas e conhecidas, o pesquisador capaz de discernir os elementos significativos da "cotidianidade", ou seja, do complexo jogo cotidiano que confere significado às práticas escolares, pode contar no máximo com uma carga conceitual e seu tirocínio, cuja aplicação, no entanto, não deve esperar socorro de nenhum vade-mecum. (Cf. AZANHA, 2011, p.154, p. 162)

Se a relevância de uma descrição densa do cotidiano escolar parece óbvia nas recomendações de Azanha às pesquisas empíricas em educação, que interesse esse conceito poderia ter para nossa discussão a respeito dos esforços do autor por relativizar conceitos abstratos usados na consideração da escola democratizada? Se, até o momento, não fizemos referência a tentativas de Azanha de descrever características concretas da escola democratizada, o que a descrição densa pode ter a ver com suas ressalvas ao abstracionismo pedagógico e aos pressupostos tomados como absolutos na avaliação pejorativa do ensino democratizado? Essas perguntas remetem ao nosso propósito, anunciado no começo do capítulo, de mostrar a insistência de Azanha na demarcação de distinções conceituais entre o ensino do ginásio seletivo e a escola básica democratizada. Temos agora condições de justificar essas afirmações.

Vimos que, nos termos de Azanha, podemos considerar as afirmações a respeito da queda da qualidade do ensino como paradigmáticas de uma variante do abstracionismo pedagógico marcada pelo equívoco de separar o desempenho do ensino, registrado pelas taxas de repetência e evasão escolar, de sua gramática escolar específica. No fundo, essa sorte de abstracionismo ignora que um certo uso do conceito de ensino e a pressuposição de sua continuidade mesmo após a expansão da escola básica são correlatos de formas 
específicas de avaliar a escola originadas no antigo ginásio. Na comparação abstrata entre a qualidade do ensino de uma e outra escola, pressupõe-se uma forma exclusiva, supostamente necessária e objetiva, de descrever o ensino e sua qualidade, válida sob quaisquer condições educacionais. Nessa perspectiva, o ensino da novidade institucional representada pela escola básica disponível a todos deve ser visto e avaliado como exatamente o mesmo de antes.

Ora, a noção de descrição densa parece-nos conveniente para caracterizar as indicações conceituais de Azanha interessadas em mostrar diferenças significativas entre o antigo ginásio e a escola democratizada. Embora o próprio autor não tenha propriamente ensaiado descrições das práticas escolares concretas, sua obra não deixa de apresentar coordenadas conceituais caras àqueles empenhados em realizar um "mapeamento" das práticas cotidianas distintivas da escola democratizada (AZANHA, 1997, p.74). Essas coordenadas, de maneira geral, procuram relativizar certas pressuposições típicas das descrições abstratas da instituição, muitas das quais comprometidas com formas de avaliar o ensino correlatas da vida escolar do antigo ginásio responsáveis por obscurecer a novidade institucional representada pela escola básica universalizada. Trata-se, no fundo, de demarcar diferenças significativas capazes de afastar a noção abstrata e geral da permanência de uma única e mesma "escola", que oferece um mesmo e único "ensino", cuja "qualidade" é de uma só natureza - embora declinante.

Dito de outro modo, ao mostrar a inadequação de conceitos abstratos e gerais usados na descrição da nova escola, Azanha procura de algum modo combater uma certa "tendência [a] procurar algo de comum a todas as entidades que geralmente subsumimos num termo geral" (WITTGENSTEIN, 2008, p. 45). Nesses termos, mostrar a ruptura representada pelas novas condições de ensino é uma forma de demarcar a limitação das formas usuais de descrever e avaliar a vida escolar consagradas pelo antigo ginásio, problematizando sua validade absoluta. A relativização dos pressupostos associados à descrição da "escola", de seu "ensino" e de sua "qualidade" procuram mostrar a contingência de formas particulares de consideração da vida escolar eventualmente tomadas como as únicas possíveis.

Tal problematização do uso abstrato dos conceitos de "escola", "ensino", etc., porém, não deve ser entendida como recomendação de proscrição incondicional do uso de termos gerais dos discursos educacionais. Ainda no capítulo sobre o abstracionismo pedagógico em Uma ideia de pesquisa educacional, Azanha deixa claro que o uso de conceitos gerais pode ser conveniente, "no sentido de determinação de elementos comuns ao processo educativo em diferentes épocas e sociedades". Os problemas aparecem somente quando essas 
"abstrações, essenciais ao trabalho teórico", são usadas como descrições de casos concretos ou ainda como diretrizes metodológicas para a atuação do "professor" abstrato (AZANHA, 2011, p. 54; 2006, p.60). Assim, "é claro que podemos falar apropriadamente de 'educação em geral' ou 'escola em geral"' num plano teórico, mesmo porque essas referências são condição para a descrição de situações educacionais reais, isto é, oferecem coordenadas conceituais para dar sentido aos fenômenos educativos que ocorrem em circunstâncias específicas. As confusões decorrem do vício abstrato de substituir essa "indispensável orientação teórica geral para o estudo da educação" pelo seu "próprio estudo", como se a "verdade fosse uma moeda cunhada". (AZANHA, 2011, p. 51, 54-55).

Nessas condições, o que Azanha põe em questão ao relativizar um certo uso geral das noções de "escola", "ensino" e "qualidade do ensino" é sua conveniência para descrever de maneira densa a singularidade de cada escola básica democratizada ou para fundamentar prescrições inequívocas a respeito da organização do ensino e da atuação do professor. Nesses termos, é como se Azanha procurasse mostrar que as regras próprias à gramática da descrição do ginásio seletivo não eram mais válidas para dar sentido à nova situação educacional instaurada com a expansão das matrículas nesse nível de ensino. E elas são ainda mais desastrosas quando se erigem em normas para lidar com as eventuais dificuldades enfrentadas na escola acessível à maioria da população. Como diz Azanha em Cultura escolar brasileira,

O simples reconhecimento da existência de uma crise na instituição da escola deveria antes a nos conduzir a rever nossas ideias sobre ela do que, apressadamente, levar a esforços para reformá-la. Nem mesmo somos capazes, atualmente, de responder, de modo interessante, à questão: 'o que é a escola?'. Não nos iludamos com o número infindável de respostas que a pesquisa educacional tem dado para uma questão que parece tão simples. Os nossos vezos ideológicos e os nossos cacoetes pretensamente científicos já nos brindaram com uma multidão de esquemas classificatórios e correlações estatísticas, mas desconhecemos inteiramente as relações efetivamente praticadas na escola. (AZANHA, 1995, pp. 70-71)

Um leitor pouco familiarizado com o estilo dos escritos de Azanha poderia ser levado a pensar que a relativização dos pressupostos das descrições da escola faça as vezes de um vestíbulo para o oferecimento posterior de conceitos precisos a respeito de como a escola deve ser descrita seguidos de veredictos a respeito do que ela deve ser, de quais devem ser suas práticas, do que é ensinar no novo contexto, etc. A expectativa de que a pesquisa 
educacional ofereça descrições e métodos garantidores do sucesso pedagógico é sempre frustrada no caso de Azanha. Uma anedota fixada pela memória de um de seus alunos não deixa margem a dúvidas a propósito de um certo antipraticismo ${ }^{33}$ do estilo de investigação educacional do autor.

\footnotetext{
Quando acusado de ser sempre mais crítico do que propositivo, costuma dizer que a filosofia analítica - que teve grande peso em sua formação intelectual - não era capaz de ajudar alguém a pregar um simples botão! Mas apontava com precisão que determinado botão não servia naquela camisa ou que seu orifício estava mal localizado. E exibia seu raro sorriso, com uma ironia socrática de quem não aponta caminhos; desafia a buscá-los (CARVALHO, 2010, p.94)
}

O que esperar, então, dos escritos de Azanha? Mais precisamente, o que esperar das advertências do autor de que o "botão" (os conceitos correlatos a práticas do ensino ginasial) não "serve" na "camisa" (uma descrição densa da escola básica democratizada)? Tentaremos agora responder a essas perguntas indicando finalmente uma relação possível entre os esforços de relativização dos conceitos e pressupostos abstratos empregados na descrição da escola democratizada, comentados neste capítulo, e o uso programático da "autonomia da escola" apontado no capítulo anterior. Pretendemos mostrar que, não obstante suas inegáveis diferenças de propósito, os escritos de Azanha a respeito da pesquisa educacional referidos há pouco ajudam a esclarecer o sentido que o autor usualmente empresta à noção de autonomia da escola em diversos contextos de sua obra. Se nossa interpretação tiver alguma plausibilidade, ficará claro que a relativização dos conceitos abstratos de "escola" e "ensino" eventualmente usados para fundamentar propostas de intervenção na realidade escolar oferece condições para a apresentação de uma nova imagem da escola democratizada potencialmente fecunda à reflexão e proposição de ações mais interessantes à sua novidade institucional.

\subsection{Diferenças significativas da escola democratizada: coordenadas conceituais}

Num artigo a respeito do ensino, Ryle observa que a iniciação do aluno em um "método" ou "modo" de fazer algo (saber fazer algo, knowing how) é muitas vezes entendida

\footnotetext{
${ }^{33} \mathrm{O}$ "praticismo" em educação - a pressuposição de que os estudos educacionais devam gerar técnicas e métodos de ensino - é duramente criticado por Azanha em Uma ideia de pesquisa educacional, como veremos no próximo capítulo.
} 
como uma prática limitadora da criatividade do aprendiz (RYLE in PETERS, 2010). Ao ensinar um modo usual de "saber fazer" (knowing how) algo como, por exemplo, escrever um poema, o professor, de acordo com essa interpretação, bloquearia o livre desenvolvimento das habilidades idiossincráticas de seus alunos. Ryle, porém, lembra que aprender um método ou modo de fazer pode ser, pelo contrário, condição da autonomia daquele que aprende. Diz ele:

\begin{abstract}
As pessoas queixam-se, às vezes, de que os Dez Mandamentos sejam, em sua maior parte, proibições, e não injunções positivas. Não repararam que o cartaz "Proibido pisar na grama" permite-nos caminhar por todos os outros lugares que escolhermos, enquanto que o cartaz "Siga pelo caminho de cascalhos" restringe muito mais nossa liberdade de movimento. Aprender um método equivale a aprender a precaver-se contra certos tipos de riscos, confusões, caminhos sem saída, rodeios desnecessários, etc. [...] Mesmo que se ensine alguém vinte tipos de coisas que fariam de seu soneto um mau soneto, ou de seu argumento um mau argumento, ele continuará tendo um espaço consideravelmente amplo dentro do qual poderá construir seu soneto ou seu argumento, e, seja ele brilhante, comum ou medíocre, estará livre ao menos dos vinte erros indicados. (RYLE in PETERS, 2010, p.80)
\end{abstract}

Nesses termos, as palavras de Ryle dissolvem a interpretação pessimista da aprendizagem de um "método", no sentido específico de um modo consagrado de fazer algo (knowing how), sugerindo uma acepção um tanto diferente dessa noção. Entretanto, não estamos interessados exatamente na descrição dos usos possíveis do conceito de método, nem mesmo em assuntos ligados às práticas de ensino e aprendizagem no contexto de uma relação pedagógica. As observações de Ryle foram invocadas neste trecho do trabalho apenas por sugerirem similaridades interessantes com os comentários de Azanha que demarcavam a inviabilidade do padrão de ensino consolidado pelo ginásio seletivo. Assim como, segundo Ryle, uma regra como "Não pise na grama" é condição para a realização de variadas ações nos limites do espectro de possibilidades por ela aberto, a interdição do uso de formas de praticar e descrever a vida escolar herdados do ginásio seletivo por Azanha projeta um campo talvez mais conveniente para a descrição e eventual encaminhamento das práticas da escola democratizada. Parafraseando a anedota, tudo se passa como se, ao dizer que um certo botão não serve para determinada camisa, Azanha liberasse o alfaiate para a procura de outros botões ou outras formas de pregá-lo no tecido.

Nesse sentido, em vez de propor panaceias pedagógicas supostamente capazes de resolver os problemas eventualmente encontrados na escola democratizada, Azanha, na 
maior parte de seus escritos sobre a vida escolar ${ }^{34}$, restringe-se a apontar o que não deve ser lá visto ou feito. Em particular, como veremos oportunamente, interessa-lhe sobretudo indicar o equívoco de tomar certas diretrizes vistas sob a ótica de uma determinada visão cristalizada do fenômeno pedagógico como orientação metodológica suficiente para a avaliação ou ação educativa. Por ora, entretanto, gostaríamos de mostrar como a relativização de certos usos abstratos das noções de escola e ensino podem apresentar a atividade da escola democratizada sob novos aspectos, mais convenientes à intepretação de sua novidade institucional. A nosso ver, essa imagem densa da escola democratizada exibida por Azanha está de algum modo implicada no uso programático da "autonomia da escola" pelo autor, como adiantamos acima.

Numa determinada passagem de Cultura escolar brasileira (1995), Azanha referese ao uso abstrato da noção de ensino em descrições da crise da escola básica democratizada que pretendiam fundamentar propostas de intervenção voltadas à solução do problema. Nas palavras do autor,

[...] dizer que na escola o professor ensina e o aluno aprende e, depois, partir para avaliar o ensino ou a aprendizagem é deter-se no vestíbulo de uma autêntica descrição. É tentar descrever condutas pelos objetivos que a norma legal lhes prescreve. É claro que o professor na sua prática busca alcançar certos objetivos e a conformar-se com certas regras, mas é claro também que, se nos ativermos a descrever a atuação do professor pelo alcance ou não de objetivos prescritos e pela observância ou não de normas estabelecidas, a nossa descrição será abstrata e no máximo poderá nos permitir chegar a uma contabilidade pedagógica que não serve senão para produzir estatísticas escolares. Nessa contabilidade, o aluno - na sua realidade social e psicológica - desaparece. A sua atividade, para nenhum efeito, consiste numa "Prática Escolar", é apenas alvo dela e só conta para fornece um número nas estatísticas. Do mesmo modo, são abstratas as descrições disponíveis sobre a administração da escola, o livro escolar, etc. (AZANHA, 1995, p. 71, grifos nossos)

Nesse trecho, Azanha chama a atenção para um uso abstrato do conceito de ensino na descrição dos supostos problemas da educação básica. Embora o comentário tenha sido escrito mais de 20 anos após o fim do exame de admissão ao ginásio, o objeto da crítica ainda é a ênfase nos resultados do ensino como critério exclusivo para descrição e avaliação do que é o ensino efetivamente praticado nas unidades escolares. Nessa contabilidade pedagógica, as efetivas práticas que têm lugar no cotidiano escolar e que, inclusive, criaram

\footnotetext{
${ }^{34}$ Por exemplo, sua Reflexão sobre a formação do professor da escola básica não é muito prescritiva, como veremos adiante. $\mathrm{O}$ mesmo vale para os artigos sobre a formação de professores em Educação: temas polêmicos, São Paulo, Martins Fontes, 1995. A obra Uma ideia de pesquisa educacional, por sua vez, não se propõe a oferecer prescrições a respeito da pesquisa educacional.
} 
condições para o surgimento dessa forma de compreender a vida escolar, permanecem na sombra. Pressupõe-se uma certa ideia de ensino que é ponto de partida para os testes que, no fim das contas, contabilizam um determinado número de reprovados que certifica, ou não, a qualidade da escola. Trata-se, ainda, de uma forma de considerar a vida escolar solidária dos antigos critérios fabris de seleção ginasial.

Não é esse, entretanto, o ponto que nos interessa sublinhar neste momento, mesmo porque já discutimos esse tema à exaustão nas páginas precedentes. Gostaríamos de assinalar um outro aspecto dessa crítica de Azanha mais interessante aos nossos propósitos presentes de mostrar algumas coordenadas conceituais traçadas pelo autor a fim de bloquear certos descaminhos descritivos prenhes de confusões abstracionistas ${ }^{35}$. Referimo-nos à ideia pressuposta nessa descrição superficial do ensino como uma relação entre o "professor que ensina" e "o aluno que aprende". Em seus textos sobre as propostas de formação de professores, em especial em Uma reflexão sobre a formação do professor da educação básica (2006), Azanha sugere algumas pistas para a caracterização mais completa dessa forma de descrição do ensino aproximando-a de uma relação pedagógica típica de um “preceptorado coletivo” herdado do antigo ginásio (AZANHA, 2006, pp. 60-61).

\begin{abstract}
A relação pedagógica preceptorial nunca foi, na verdade, uma relação escolar, isto é, o seu contorno natural não era a escola, mas a casa, o convento, o castelo, etc. Há algumas décadas, no Brasil principalmente, para a nascente e escassa escola pública pretendeu-se - e se conseguiu, em parte - transplantar um estilo de relacionamento pedagógico que era, no seu aspecto geral, uma espécie de "preceptorado coletivo" (AZANHA, 2006, pp. 60-61)
\end{abstract}

Nesses termos, a ideia de que "o professor ensina" e o "aluno aprende" e de que, presumivelmente, a reprovação do aluno indica a qualidade duvidosa do ensino recebido corresponde a uma forma superficial e abstrata de descrever o que se passa numa escola democratizada. A superficialidade da descrição parece enraizar-se no pressuposto, altamente discutível, de que a relação pedagógica do ensino deva ser sempre concebida como uma relação preceptorial entre duas entidades abstratas - o "professor que ensina" e o "aluno que (não) aprende" -, tomados como objetos independentes do contexto mais amplo da vida cotidiana da instituição. Ao abstrair a relação pedagógica da complexa trama institucional e de sua dinâmica cotidiana, essas descrições são incapazes de perceber as diferenças

\footnotetext{
${ }^{35}$ Seguimos aqui o exercício do próprio autor em Uma ideia de pesquisa educacional (p.78), que, ao tratar da pesquisa do cotidiano como uma totalidade, decide "bloquear certos descaminhos" frequentemente seguidos no estudo do tema.
} 
significativas entre o "ensino" do antigo ginásio e o "ensino" da escola acessível à maioria da população, subsumindo as distintas práticas de ensino de uma e outra vida escolar à mesma imagem abstrata da relação pedagógica.

Esse exercício abstracionista, aliás, parece esclarecer a assimilação apressada entre o antigo ginásio e a escola democratizada presente numa citação já transcrita no primeiro capítulo deste trabalho que expressa o pressuposto de que "as entidades "escola pública de trinta anos atrás' e 'escola pública de hoje' sejam a mesma instituição, que antes cumpria bem suas funções e agora não" (2006, p. 97). A descrição superficial da escola como um lugar indiferente com salas de aula maiores ou menores em que "o professor ensina" e "o aluno aprende" torna irrelevante questões decisivas acerca das relações históricas da escola com seu entorno, da proveniência dos alunos, da maior ou menor seletividade do ingresso, do rigor das expectativas de aprendizagem e avaliação dos professores, dos princípios que a instituição esposa materializados nos gestos cotidianos de seus agentes, etc. Enfim, tal "visão petrificada" da relação pedagógica não capta a "novidade social e cultural" do que acontece na escola básica altamente expandida, desprezando essa variedade de sutis distinções como detalhes insignificantes de uma mesma "escola pública" (2006, pp. 60-62).

Não é ocioso lembrar, entretanto, que essas observações de Azanha não implicam que nunca se possa falar com propriedade da relação pedagógica e do ensino recorrendo a termos gerais como "a escola pública" ou o "professor" e o "aluno". Tomemos um exemplo para evitar o mal-entendido. O próprio Azanha, por ocasião da reforma do ensino de 1967, justificava a abolição da seriação anual e a adoção do ciclo de dois anos no ensino primário recorrendo a um conceito geral da relação pedagógica. A autonomia concedida ao professor para organizar as rotinas de alfabetização num prazo maior de tempo era defendida nos seguintes termos, emprestados de Gusdorf:

\footnotetext{
Mesmo num ensino de massa, e por muito confusas que sejam as relações que o constituem, a educação continua a ser um caso pessoal, um colóquio singular e intermitente: no seio da massa coletiva estabelece-se um "encontro a dois" entre o aluno isolado e aquele ou aqueles dos seus professores cuja competência reconheceu [...] (GUSDORF apud AZANHA, 1987, p. 84)
}

É certo que a caracterização do encontro singular entre "o professor" e "o aluno" nos termos de Gusdorf, pelo menos no contexto original de sua obra Professores para quê? (2003), não diz respeito exatamente às entrevistas corriqueiras entre alunos e professores numa escola de massas. $\mathrm{O}$ encontro singular delineado nessas palavras é sobretudo aquele 
travado entre um "mestre" e seu "discípulo" numa relação de "mestria" que, mesmo se estabelecendo nas rotinas e aulas da escola, ultrapassa as atribuições profissionais do professor, o programa de estudos, as exigências de aprendizagem do aluno, etc ${ }^{36}$. Não obstante, Azanha apropria-se desse trecho da obra do filósofo francês para defender o princípio de autonomia didática do professor primário nos quadros de uma regulamentação flexível do programa de estudos do ciclo inicial. Poderíamos, então, concluir que o autor, nesse caso, incorre numa contradição ao falar do professor em geral, isolado do contexto institucional da escola?

A resposta a essa pergunta só nos poria em apuros se ignorássemos as diferenças evidentes entre os propósitos específicos do uso de noções gerais nessa ocasião e naquelas outras, apontadas acima, em que o autor censura a descrição superficial do "ensino" ou da "relação pedagógica" nesses termos. Obviamente, não se trata de uma contradição falar do "professor que ensina" para sublinhar um princípio de atuação do professor que não pretende se erigir numa forma de descrição, avaliação ou mesmo orientação das práticas de ensino efetivas. Nesse trecho, Azanha simplesmente apresenta um princípio de como o professor primário deve ser visto ou concebido para os fins estritos de valorização da marca pessoal embora não antiinstitucional - de sua atividade ${ }^{37}$. Em outras palavras, seu interesse é defender a necessidade de que o professor tenha liberdade para "assumir na sua plenitude o papel de educador" e escolher as formas de trabalho mais interessantes para seu êxito na alfabetização dos alunos das séries iniciais (1987, p.84). Muito diferente disso, porém, é falar do "professor que ensina" e do "aluno que aprende" com o objetivo de descrever, julgar ou direcionar o desempenho concreto dessas "ficções" linguísticas (AZANHA, 2006, p. 60). Como diz Azanha, "não se trata de discutir a necessidade teórica ou prática de conceitos gerais abstratos, mas a utilidade que elas possam ter para fundamentar e orientar práticas docentes que devem ocorrer em situações escolares concretas muito diferentes entre si” (2006, p.60)

\footnotetext{
${ }^{36}$ GUSDORF, Georges. Professores para quê? Para uma pedagogia da pedagogia. São Paulo: Martins Fontes, 2003. Veja-se, por exemplo, dentre as muitas passagens do capítulo 1 sobre a "função docente", o seguinte trecho a respeito do reconhecimento, pelo aluno, de um mestre em seu professor (p.70): "O encontro frente a frente sobre temas impostos pelo calendário escolar é apenas a máscara desse outro encontro mais secreto, de caráter quase iniciático. O mestre lá está: se é verdadeiramente um mestre, à altura de sua mestria, atesta com sua presença que é alguém"

${ }^{37}$ Ver Oakeshott sobre a noção de "estilo" (style). O estilo pessoal de um professor, para o autor, tem a ver com uma forma particular de atuação dependente de sua prática profissional, não de eventuais características psicológicas. OAKESHOTT, Michael. Learning and teaching. In PETERS, R.S. (org.).The concept of education, Routledge, 2010, p. 121-122.
} 
Tomemos então outro exemplo para esclarecer o uso abstrato de conceitos para descrever e orientar a atuação concreta do professor na escola segundo o pressuposto preceptorial da relação pedagógica criticado por Azanha. Trata-se de um artigo a respeito da “educação geográfica" nas escolas ${ }^{38}$. Diante da constatação - não baseada em nenhum tipo de estudo empírico - de que "no processo de aprendizagem [de geografia na escola], a ênfase tem sido dada ao conteúdo e aos resultados da avaliação, e não em como criar condições para a aprendizagem", a autora apresenta algumas recomendações didáticas fundamentadas na "epistemologia genética" para lidar com tal problema. No exemplo, a autora presta socorro ao professor interessado em ensinar o conceito de lugar:

\begin{abstract}
A epistemologia genética é importante porque nos revela que, para compreender algumas noções que estruturam o conhecimento geográfico, como, por exemplo, o conceito de lugar, é necessário que a criança desenhe o seu lugar de vivência (rua, escola, moradia e outros não tão próximos); mas, para agir sobre ele e transformá-lo, as atividades devem motivá-la a pensar sobre as noções e conceitos, relacionando o senso comum (vivência) com o conhecimento científico. (CASTELLAR, 2005, p.215)
\end{abstract}

Sem pôr em questão o mérito dos conhecimentos do campo de estudos específico da autora nem mesmo as dificuldades lógicas da transposição de um conhecimento proposicional do corpo teórico dessa disciplina numa diretriz pedagógica inequívoca ${ }^{39}$, esse trecho, embora descontextualizado, dá ideia da concepção da relação pedagógica na escola contemporânea como uma interação entre um "professor que ensina" e uma "criança que aprende". A entidade linguística "a criança”, nesse caso, pode até ser útil para os propósitos de descrição de certas propriedades cognitivas estudadas no âmbito da "epistemologia genética". No entanto, nos dizeres de Azanha, ela se transforma numa "ficção" ou um "parceiro de um jogo abstrato" quando pretende ser descritiva das relações escolares ou orientar as práticas de ensino na escola democratizada. (2006, p. 60). Prova maior da superficialidade desse tipo de descrição é que a "criança” focalizada pode ser tanto um aluno numa escola privada da elite, quanto um aluno de uma escola localizada na periferia de uma grande metrópole ou ainda um filho de um europeu recebendo instrução de seu pai em casa.

\footnotetext{
38 Trecho extraído de CASTELLAR, Sônia. Educação geográfica: a psicogenética e o conhecimento escolar. Caderno Cedes, vol. 25, $\mathrm{n}^{\mathrm{o}}$ 66, Campinas, maio/agosto de 2006. Disponível em http://ftp-acd.puccampinas.edu.br/pub/professores/cchsa/marasalvucci/Projeto\%20de\%20atua\%C3\%A7\%C3\%A3o\%20Geogr afia\%20I/Educa\%C3\%A7\%C3\%A3o\%20Geogr\%C3\%A1fica \%20a\%20psicogen\%C3\%A9tica\%20e\%200 $\% 20$ conhecimento\%20escolar.doc. Acessado em 08/11/2015.

${ }^{39}$ Temas discutidos no próximo capítulo.
} 
Dificilmente concordaríamos em que as diferenças do "ensino" ou da "relação pedagógica" e de seus agentes nesses variados espaços sejam irrelevantes para o ensino de geografia.

Nessas condições, a caracterização da relação pedagógica como uma relação preceptorial entre alguém que ensina e alguém que aprende não é problemática em si, em abstrato - se quisermos abusar do uso do termo. Os problemas aparecem somente quando o uso dos conceitos de ensino e de relação pedagógica pressupõe a validade geral desse tipo de relacionamento como uma característica essencial das práticas de ensino concretas sob quaisquer circunstâncias. Nos termos de Ryle, trata-se de uma descrição superficial fundada em certos usos do conceito de ensino e de relação pedagógica que põem na sombra as diferenças significativas do desempenho de professores e alunos em situações que são tomadas como se fossem exatamente iguais. Segundo essa descrição, somos induzidos a ver a "natureza" da relação pedagógica no antigo ginásio e na escola democratizada do mesmo modo como pretendíamos ver uma mesma "Dama de Copas" no Poker ou no Bridge, isto é, como uma entidade dotada de propriedades essenciais independentes do jogo em questão (AZANHA, 2006, p. 58).

Não deixa de ser curioso, no entanto, que o próprio Azanha, ao caracterizar o antigo ginásio e suas respectivas relações pedagógicas nessas e em outras passagens de sua obra, não se preocupe em estabelecer distinções entre as práticas de ensino e a vida escolar das diferentes unidades escolares ginasiais. $\mathrm{O}$ antigo ginásio é geralmente apresentado por ele como uma instituição seletiva e modelada por um tipo de relacionamento pedagógico semelhante a um "preceptorado coletivo", como dissemos. Contudo, longe de constituir uma negligência descritiva, parece-nos razoável supor que essa postura é conveniente ao propósito de Azanha de acentuar o "aspecto geral" de um "padrão de ensino" correlato a uma visão elitista da escola pública e de seus propósitos sociais (2006, p. 61). Essa espécie de caricatura procura assim estabelecer um contraste nítido capaz de mostrar a ruptura representada pela escola democratizada, ou seja, aquilo que ela não é nem deve aspirar a ser. Não por acaso, a nosso ver, as relações pedagógicas do antigo ginásio são equiparadas ao preceptorado pelo autor. Seu interesse é evidenciar o abismo que separa uma instituição educativa privada de uma instituição educativa pública, um fosso muitas vezes turvado pela névoa informe que iguala as diferenças de "ensino" nas descrições abstratas da relação professor-aluno. Nas palavras de Azanha, "a escola de hoje é uma ruptura com a escola do passado, sempre inspirada numa visão preceptorial da relação pedagógica” (2006, p. 62). 
A oposição entre a visão preceptorial da relação pedagógica e os outros significados do ensino na escola democratizada, porém, não corresponde simplesmente à oposição entre uma "relação de ensino individual" e "uma relação de ensino coletivo", como se a primeira fosse o paradigma do ensino privado e a segunda, de um ensino escolar público (2006, p.61). Basta lembrar que o antigo ginásio, apesar de modelado segundo formas de relacionamento preceptoriais na visão de Azanha, era igualmente uma instituição educativa coletiva, com ensino simultâneo e seriado, características geralmente reconhecidas como distintivas de uma forma escolar de ensino. O ponto crucial é que a escola básica democratizada, acessível à maior parte da população na forma de um direito social, compromete-se com o princípio público de iniciação das novas gerações num legado comum de bens simbólicos, habilidades, conhecimentos, etc. Esse não era o caso do ginásio seletivo, em que a escolarização era em geral um privilégio reservado a um grupo seleto cuja frequência à escola compunha parte das estratégias privadas de reprodução familiar (AZANHA, 1995, p. 112). Essa distinção é claramente traçada por Azanha pelo recurso a um trecho de Hannah Arendt em que a autora define a escola como a

Instituição que interpomos entre o domínio privado do lar e o mundo com o fito de fazer com que seja possível a transição, de alguma forma, da família para o mundo. Aqui, o comparecimento não é exigido pela família, e sim pelo Estado, isto é, o mundo público, e assim, em relação à criança, a escola representa em certo sentido o mundo. (ARENDT, 2007, pp. 238-239)

Ora, se a escola democratizada não deve ser vista como uma continuidade da "escola de trinta anos atrás", mas como uma "novidade social e cultural" cujo ensino não deve ser reduzido a uma relação pedagógica à imagem do preceptorado coletivo dos antigos ginásios, como devemos descrevê-la e como deve ser o ensino lá? Conforme já havíamos antecipado, não encontraremos respostas positivas para essas indagações nos escritos de Azanha. O que nos resta da leitura de suas reflexões sobre a vida escolar são algumas coordenadas que vetam certos usos dos conceitos frequentes na descrição, avaliação e condução das práticas escolares na nova escola. Veja-se, por exemplo, o seguinte comentário:

Nesse novo espaço institucional, o desempenho do professor não pode mais ser pensado como uma simples questão de formação teórica de alguém que ensina, como também o desempenho do aluno não mais pode ser considerado como uma simples questão de motivação e de esforço individuais. (AZANHA, 2006, p. 62, grifos nosso) 
A vagueza do autor, no entanto, não deve ser recebida de maneira pessimista. Como objetaria Wittgenstein, "não é a imagem pouco nítida justamente aquela de que, com frequência, precisamos?" (1999, p. 54). De fato, as demarcações conceituais de Azanha são suficientes para lançar luz sobre novos aspectos da escola democratizada potencialmente fecundos a esforços de descrição densa e eventual orientação de suas práticas. Parafraseando Ryle mais uma vez, o anúncio de que "não pisemos na grama" do ensino ginasial é também um convite para uma caminhada pelos meandros da escola democratizada. Em outras palavras, ao denunciar os equívocos do abstracionismo pedagógico, perpetrado tanto pelos detratores do ensino democratizado quanto por certas tendências da pesquisa educacional, Azanha afasta o padrão de ensino ginasial e sua mentalidade pedagógica correlata como referências válidas para a compreensão e encaminhamento das dificuldades eventualmente encontradas na nova instituição.

É à luz desse amplo quadro que o uso programático da "autonomia da escola" por Azanha deve ser considerado. O programa de atribuição de autonomia às escolas, nesses termos, é uma resposta ao fim do padrão de ensino ginasial demarcado por Azanha. A relativização de certos pressupostos das descrições da escola democratizada e das tecnologias educacionais muitas vezes daí derivadas parece apontar para o reconhecimento da novidade dessa vida escolar e da inexistência de soluções prévias às eventuais dificuldades relacionadas às mudanças verificadas na dinâmica cotidiana da instituição (AZANHA, 1987, p.44). Dito de outro modo, ao bloquear as descrições abstracionistas e superficiais frequentemente herdadas da gramática ginasial, Azanha sugere novas perspectivas de descrição e orientação das práticas mais convenientes à realidade específica da nova escola. Uma das respostas possíveis capaz de acolher a novidade dessa situação é justamente a reivindicação de autonomia às unidades escolares.

Com efeito, apenas um olhar atento às diferenças significativas escondidas sob a poeira informe do abstracionismo poderia também notar que, assim como as cidades de Calvino, cada escola democratizada tem especificidades ignoradas por um viajante distraído. Passemos então a observar como a multiplicidade de qualidades projetada pelo mapa conceitual de Azanha - ou pelo menos por algo como um negativo fotográfico - confere centralidade à vida cotidiana da escola democratizada e à formulação de propostas pedagógicas autônomas. 


\title{
CAPÍTULO 3 -
}

\section{ALÉM DO MÉTODO: VIDA ESCOLAR E AUTONOMIA DA ESCOLA}

\author{
Na pedagogia, como no restante: desde que cessamos \\ de refletir sobre os casos particulares (ora, neste \\ domínio, todos os casos são particulares), nós \\ procuramos, para regular nossos atos, a sombra de \\ uma boa doutrina, a proteção da autoridade \\ competente, a caução do decreto, a assinatura \\ ideológica em branco. Em seguida, nos instalamos \\ sobre certezas que nada pode alterar, nem mesmo o \\ desmentido cotidiano do real.
}

Daniel Pennac, Diário de escola

No primeiro capítulo, observamos que a atribuição de autonomia às escolas proposta por Azanha, de acordo com um uso programático próprio da expressão, é apresentada desde sua primeira ocorrência na obra do autor como uma alternativa à melhoria da qualidade do ensino público. Notamos ainda que a noção de "qualidade do ensino" frequentemente associada à sua proposta deve ser devidamente qualificada, sob pena de ser compreendida como uma variável abstrata ou uma meta a-histórica. Diante dessas ressalvas, concluímos o capítulo com a firmação de que o uso programático da noção de autonomia da escola procurava responder a impasses de uma situação educacional específica: a escola básica democratizada.

Já no segundo capítulo, procuramos estabelecer, por meio de um certo desvio, um quadro de referências que lançasse luz sobre tal uso da noção de autonomia da escola. Nesse desvio, apresentamos o estilo de investigação característico do autor, marcado pelo exercício de discussão de pressupostos tomados como absolutos na avaliação e descrição da escola democratizada. Sem dúvida, os pressupostos mais questionados nos escritos de Azanha referiam-se aos antigos critérios de avaliação da qualidade do ensino herdados do ginásio seletivo. Entre outras coisas, afirmamos que esses conceitos correlatos ao ensino ginasial pregresso pressupunham a ideia de que a qualidade do ensino deveria sempre ser medida por índices de rendimento dados pelas taxas de evasão e reprovação, abstraídas de qualquer consideração acerca das transformações nas condições de ensino.

Outro conceito correlato à antiga maneira de praticar a vida escolar igualmente refutado por Azanha dizia respeito à descrição da relação pedagógica na nova escola. Indicamos que, segundo essa descrição, a relação pedagógica concreta numa sala de aula da escola democratizada deveria sempre ser vista como uma relação preceptorial entre interlocutores abstratos - o professor que ensina e o aluno que aprende. Ao ressaltar a 
relatividade dessas formas de compreensão da escola pública democratizada, Azanha, segundo nossa interpretação, procurava chamar a atenção para as diferenças inéditas dessa novidade institucional e para a necessidade de revisão de conceitos eventualmente subjacentes a recomendações destinadas a orientar suas práticas.

À guisa de síntese das discussões anteriores, pretendemos mostrar agora, à luz das referências apresentadas no segundo capítulo, que o uso programático da "autonomia da escola" por Azanha, ao destacar diferenças significativas da escola democratizada, sugere coordenadas originais para a consideração de suas alegadas dificuldades - se se quiser, referências para melhorar a "qualidade" de seu ensino, no sentido devidamente qualificado pelas ressalvas discutidas desde o primeiro capítulo. Em outras palavras, queremos argumentar que a proposta de autonomia às escolas, considerada sobre o pano de fundo dos variados escritos de Azanha apresentados há pouco, procura oferecer indícios interessantes para a compreensão e eventual orientação das práticas escolares concretas em coerência com o caráter inédito da escola democratizada. Se lograrmos realizar esse objetivo, nossa afirmação inicial, registrada ainda no primeiro capítulo, de que o uso de autonomia da escola por Azanha representa uma resposta programática à crise do padrão de ensino ginasial estará finalmente justificada.

Para isso, apresentaremos preliminarmente as críticas de Azanha aos pressupostos dos cursos de formação continuada de professores adotados como estratégia de melhoria da qualidade do ensino público após a expansão do acesso à escola básica. A explicitação das ressalvas às noções a respeito do ensino e da vida escolar pressupostas nesses cursos nos dará a chance de destacar, por contraste, o significado "indicativo de uma direção na solução de problemas educacionais" fixado pelo uso programático de "autonomia da escola" pelo autor (AZANHA, 1995, p.134). A escolha desse percurso não é casual. Em diversos comentários a propósito da autonomia da escola, como os encontrados nos textos Melhoria do ensino e autonomia da escola (1995), Autonomia da escola: um reexame (1995), Comentário sobre a formação dos professores em São Paulo (1995), Proposta pedagógica e autonomia da escola (1995) e Uma reflexão sobre a formação do professor da escola básica (1995), Azanha opõe alguns pressupostos dos programas de formação de professores, sobretudo aqueles característicos de modalidades de formação continuada, à consideração da vida escolar e à defesa da autonomia da escola. No final do capítulo, esperamos que as razões para tal dicotomia sejam esclarecidas. 


\subsection{O baconismo na educação: as tecnologias educacionais}

A denúncia dos equívocos dos cursos de formação continuada de professores figura repetidas vezes nos escritos de Azanha. Se levarmos a sério as indicações do autor, a frequência desse tópico em sua obra pode bem corresponder à insistência com que a atualização de professores era adotada pelas administrações públicas como estratégia de melhoria da qualidade do ensino da escola democratizada nas décadas de 1990 e 2000 - pelo menos na rede estadual paulista (1995, p. 25; p. 201). De fato, a suposição de que os problemas encontrados na escola deveriam ser resolvidos ou atenuados mediante a formação individual do professor constituía, segundo Azanha, um pressuposto banalizado dos planos de melhoria do ensino público. Para os proponentes desses cursos, melhorar a escola pública significava, sobretudo, melhorar a prática de ensino de um professor ou de um conjunto de professores (AZANHA, 1995, pp. 201-204).

Para Azanha, essa maneira de tratar as dificuldades verificadas na escola pública revelava uma "visão tecnológica do assunto":

\footnotetext{
Quando se coloca todo o problema da melhoria da escola em cursos para professores, tem-se uma visão tecnológica do assunto. Acha-se que a escola vai mal porque o professor não conhece tecnologia disto ou daquilo. Não é por aí. Eventualmente, pode ser que seja, mas apenas complementarmente. [...] Nestes cursos de reciclagem de professores vai embutida essa visão tecnológica do ensino. É uma visão estreita. (AZANHA, 1995, p. 25)
}

Aparentemente, ao se referir à visão tecnológica do ensino pressuposta na oferta de cursos de formação continuada para professores, Azanha não faz alusão apenas àquelas palestras, oficinas e demais atividades voltadas à transmissão de procedimentos didáticos baseados no uso de aparelhos tecnológicos modernos, tais como recursos audiovisuais ou computadores. A noção de tecnologia educacional empregada pelo autor nessa passagem é provavelmente mais abrangente, mesmo porque os temas desses cursos podem compreender assuntos que extrapolam a incorporação desse aparato tecnológico nas formas de ensino. A expressão tecnologia educacional é antes usada pelo autor num sentido mais generoso, conforme definido em uma nota de seu comentário a respeito da obra de Alain em Alain ou A pedagogia da dificuldade (1987, p. 44). A expressão, segundo ele, deveria ser tomada "num sentido amplo para designar não apenas certas técnicas de ensino, como também toda tentativa de aplicar à educação, em qualquer dos seus aspectos, princípios que se pretendem cientificamente fundamentados" (1987, p. 44, grifos nossos). 
É certo que essa definição alargada de tecnologia educacional atende a propósitos específicos do texto em questão. No entanto, a revisitação constante, por Azanha, dos problemas provenientes das tentativas de derivar práticas de ensino de conhecimentos científicos sobre aspectos variados do fenômeno educativo sugere que suas dúvidas a respeito das "tecnologias educacionais" não se limitam à idolatria das novas técnicas didáticas, certamente característica dos cursos de aperfeiçoamento docente. As suspeitas do autor, na realidade, recobrem a pressuposição mais geral - discutida em outros escritos - de que regras e práticas seguras de ensino possam ser derivadas de conhecimentos teóricos sobre a educação ou, de maneira mais específica, que o ensino seja a aplicação eficiente de um método cientificamente fundamentado. Trata-se, no fundo, de uma pressuposição típica de uma tradição do pensamento pedagógico filiada àquilo que Azanha designou em outras oportunidades de baconismo na educação (AZANHA, 2011).

A discussão desse tema na obra de Azanha é complexa demais para os objetivos desta parte do trabalho. Para os nossos modestos propósitos, é suficiente registrar que, para Azanha, as concepções de Bacon a respeito da ciência e da relação entre a investigação científica e a geração de tecnologia exerceram grande influência numa vertente do pensamento pedagógico inaugurada pela transposição realizada pela obra de Comênio (Comenius, segundo a grafia latina) no século XVII, em particular por sua Didática Magna (2011). Em linhas gerais, assim como Bacon pretendia reformar as ciências por meio da elaboração e introdução de um método fundado na observação da natureza, Comênio teria se dedicado a formular um método geral ou um conjunto definido de regras que garantissem o êxito de qualquer ensino. De acordo com sua célebre fórmula, tratava-se de descobrir, a partir da observação, "a arte universal de ensinar tudo a todos" (COMENIUS, 2011, p. 13). Nesses termos, o êxito do ensino seria simplesmente uma questão de método: "Como para Bacon fazer ciência era aplicar um método, Comênio imaginou que ensinar era também a aplicação de um método" (AZANHA, 2006, p.55).

A fim de deixar clara a afinidade apontada por Azanha entre a obra dos dois reformadores, comparemos brevemente os excertos retirados do Novum Organun, de Bacon, e da Didática Magna, de Comênio.

Ciência e poder no homem coincidem, uma vez que, sendo a causa ignorada, frustra-se o efeito. Pois a natureza não se vence, senão quando se lhe obedece. E o que à contemplação apresenta-se como causa é regra na prática. (BACON, 1973, p. 19) 
A verdadeira e legítima meta das ciências é a de dotar a vida humana de novos inventos e recursos. (BACON, 1973, p. 55)

Está claro que essa ordem que desejamos como ideia universal da arte de ensinar e aprender tudo só pode ser extraída da escola da natureza. Feito isto, as coisas artificiais ocorrerão com facilidade e espontaneidade, assim como ocorrem com facilidade e espontaneidade as coisas naturais [...] Esperamos que observando o modo como a natureza procede para fazer isto ou aquilo, sejamos convencidos a proceder de modo análogo. (COMENIUS, 2011, P. 131)

O princípio deve ser o de conformar, do modo mais exato possível, as operações da arte [de ensinar] às normas segundo as quais a natureza obra (COMENIUS, 2011, p. 146)

Influenciado pela obra de Bacon, Comênio esforçou-se por extrair da observação da natureza um conjunto de princípios sobre o qual fundar - "como sobre rocha imóvel" - sua arte de ensinar (2011, p. 129). A eficiência do ensino e da aprendizagem seria assim garantida pela observância de princípios auferidos de ocorrências naturais como o desenvolvimento de uma ave ou de uma planta ${ }^{40}$. Entre as regras integrantes do ordenado e sistemático método de ensino exposto em sua obra, Comênio enumera, por exemplo, a adoção na organização do ensino da clareza e ordem exibidas pela natureza; a progressão natural do ensino do que é mais fácil para aquilo que é mais difícil, a exemplo do desenvolvimento do organismo de uma ave; a oferta do ensino na idade oportuna, à semelhança do florescimento das árvores na estação propícia, etc. A crença de Comênio na eficácia de seu método era tal que ele não deixava de comentar que, regulado por tais princípios, um professor interessado, independentemente de seu maior ou menor tirocínio na docência, não encontraria dificuldades para "ensinar tudo a todos os jovens que vão à escola, sejam quantos forem", pois, "se tudo for escrupulosamente observado, é quase impossível que as escolas não atinjam seu fim" (2011, p.127; p.163). Nesses termos, Comênio compartilha com Bacon a ideia de que o conhecimento científico da natureza é capaz de proporcionar regras seguras capazes de otimizar a intervenção humana na realidade e fundamentar inventos tecnológicos - ou, na linguagem usada em sua Didática Magna, "artes", como a de ensinar. Por se ordenar segundo o conhecimento das ocorrências necessárias da natureza, o artefato educacional de Comênio prometia êxito universal.

\footnotetext{
${ }^{40} \mathrm{Na}$ verdade, Comênio apresenta várias analogias entre o ensino e essas ocorrências naturais para ilustrar os princípios que devem orientar sua arte de ensinar. Para ficar em apenas um exemplo, ao expor os princípios de "como ensinar e aprender com a certeza de atingir o objetivo", Comênio recorre à seguinte analogia para justificar o princípio da clareza e da ordem necessárias a tal ensino: "Por exemplo, ao formar um passarinho, a natureza em dado momento constitui os ossos, os nervos e as veias, e em outro fortalece-lhe a carne, recobreo de pele e depois reveste-o de penas, para em seguida ensiná-lo a voar.” (2011, p. 153). Essas metáforas são abundantes na parte do livro em que Comênio procura fundamentar seu método na observação da natureza. Cf COMENIUS (2011), capítulos 16, 17 e seguintes.
} 
Evidentemente, o "método" ou a "arte universal" de Comênio concentra-se na recomendação de tecnologias educacionais voltadas para a otimização do ato de ensinar no contexto de uma relação pedagógica entre professor e aluno(s). Embora o autor se ocupe também de outros aspectos contextuais do ensino - a condição dos edifícios escolares, a idade oportuna para o ingresso na escola, etc. - a ordem natural que Comênio pretende imprimir às escolas de seu tempo pressupõe a relação entre um professor e um aluno, como sugerem os excertos referidos acima. Voltaremos a esse assunto mais adiante. Por ora, essa observação é importante por destacar que o baconismo na educação é caracterizado essencialmente pela prioridade concedida ao ensino concebido como uma relação entre um professor e um grupo de alunos regulada por um conjunto definido de regras ou princípios um método. Nesse particular, apesar das óbvias diferenças de ênfase, o baconismo pressuposto nos cursos de formação continuada de professores referidos por Azanha não é muito diferente daquele demonstrado pelo fundador dessa tradição pedagógica. É claro que ninguém à época de Azanha apresentaria o entusiasmo comeniano na eficiência infalível de um método e de sua autonomia em relação a outras condições exteriores aos procedimentos didáticos. No entanto, como nos lembra o autor, a ideia de que o ato de ensinar possa ser otimizado pelo recurso a um conjunto de regras constitui um pressuposto absoluto do que em geral é reconhecido como o campo de estudos da Didática (AZANHA, 1987, p. 73).

O fato é que, em sua versão comeniana ou em variações posteriores menos entusiásticas, o baconismo na educação, de acordo com Azanha, consolidou pressupostos problemáticos quanto à relação entre conhecimento científico e seus possíveis resultados práticos, as tecnologias educacionais. Esses pressupostos consistem na ideia de que os conhecimentos teóricos sobre a educação devem sempre gerar tecnologias educacionais e, inversamente, que as práticas de ensino devem sempre se fundamentar em métodos e conhecimentos científicos sobre o fenômeno educativo, a bem de sua racionalização e otimização. Essas pressuposições, na opinião de Azanha, geraram efeitos desastrosos tanto para a prática educativa quanto para a pesquisa educacional.

No campo da pesquisa, ao menos no cenário brasileiro tratado pelo autor em Uma ideia de pesquisa educacional (2011), a excessiva preocupação com os eventuais resultados práticos das investigações educacionais - o praticismo -, além de multiplicar trabalhos interessados exclusivamente na formulação de métodos de ensino, acabou por reduzir significativamente os "esforços teóricos" capazes de "tornar interessante a investigação educacional empírica" (2011, p. 20). Assim, ironicamente, a substituição da devida 
qualificação teórica das investigações educacionais pela resposta imediata a temas vistos como relevantes do ponto de vista de sua utilidade provocou a "penúria de resultados práticos" do praticismo. Segundo o autor, boa parte das pesquisas sobre questões "práticas" não passariam de simples relacionamento de informações empíricas pouco interessante até para possíveis intervenções na realidade educacional estudada. (2011, p.21)

Mais importantes para a nossa argumentação, entretanto, são as consequências funestas do baconismo para a compreensão e orientação das práticas da escola democratizada. Esses desdobramentos podem ser exemplificados justamente pelas aspirações dos cursos de aperfeiçoamento docente rechaçados por Azanha. Como vimos, esses cursos frequentemente procuravam atualizar o professor em novas tecnologias educacionais supostamente aplicáveis a situações concretas de ensino. Não raro, essas tecnologias eram justificadas como transposições, para a prática educativa, de conhecimentos teoricamente fundamentados sobre a aprendizagem, o desenvolvimento cognitivo e emocional da criança e mesmo sobre outros aspectos da educação escolar (AZANHA, 1987, p. 49; 1995, pp. 202-203; 2006, p.56). De acordo com essa perspectiva, o êxito do ensino dependeria do conhecimento e da correta aplicação, pelo professor, de metodologias e tecnologias baseadas em certos conhecimentos psicológicos ou de outra natureza.

No comentário já citado sobre a obra de Alain, Azanha chega a aventar a hipótese de que tal entusiasmo cientificista gerado pela visão baconiana da ciência como produtora de tecnologia é, se não o grande responsável, ao menos um fator relevante na compreensão dos problemas atribuídos à escola pública democratizada. Nas palavras do autor, as "tecnologias educacionais com velocidades (sic) científicas" introduzidas para resolver a alegada má qualidade do ensino público teriam ocasionado, inversamente, o agravamento da situação (1987, p. 44). Essa mentalidade "cientifizada", no afã de racionalizar a ação educativa, teria sido tentada a "fazer as mais extravagantes ilações para o âmbito da educação a partir do que se supõe sejam conquistas definitivas da ciência" (1987, p. 49). À parte os eventuais exageros dessa explicação, a observação de Azanha a respeito dos efeitos deletérios dessa visão tecnológica no encaminhamento dos problemas da escola democratizada merece nossa atenção.

As ressalvas do autor referem-se sobretudo à redução da relação pedagógica e do ensino à mera aplicação de um método fundamentado em outros saberes, presente tacitamente nas propostas de formação de professores. Dada a centralidade da ideia de 
método na tradição pedagógica inspirada em Comênio, não poderia ser diferente. Contudo, ainda no texto sobre Alain, Azanha elenca exemplos de recomendações discutíveis derivadas de conhecimentos das ciências humanas para orientar as práticas escolares num sentido mais abrangente - isto é, um rol de tecnologias educacionais no sentido amplo do termo. Por exemplo, um lugar-comum pretensamente científico erigido em tecnologia educacional e questionado por Azanha na ocasião é a presunção do êxito educativo seguro da "integração lar-escola" (AZANHA, 1987, pp. 51-53). Segundo o autor, a "decantada integração escolacomunidade ou integração escola-família" é geralmente vista como "condição do êxito educativo", interpretação virtualmente corroborada por considerações da psicologia e da sociologia escolar. Entretanto, nas palavras de Azanha, “isso não é aprioristicamente óbvio e precisaria ser empiricamente demonstrado" (1987, p.52). As dúvidas apresentadas pelo autor devem-se ao fato de que as diferenças iniludíveis entre o ambiente doméstico, de um lado, e a instituição escolar, de outro, podem bem ser consideradas, ao contrário, experiências igualmente importantes na "realização e afirmação da personalidade infantil" (1987, p. 52). Desse modo, a possível constatação, pela psicologia ou sociologia, das virtudes de tal integração não é suficiente para a aceitação unânime da medida pela escola, cabendo portanto indagar: "Quais são as considerações científicas da psicologia e da sociologia que fundamentam a ideia da excelência educativa dessa integração?” (1987, p. 52).

Veremos oportunamente que, de acordo com observações do próprio Azanha em outras oportunidades, mesmo a comprovação científica dessas asserções da psicologia e da sociologia ou de quaisquer outros estudos teóricos sobre a educação não é suficiente para autorizar a transposição imediata e acrítica de suas conclusões para a prática educativa sem a devida consideração dos programas educacionais que veiculam. Por ora, porém, concentremo-nos na crítica de Azanha à ideia de que ensinar seja simplesmente uma questão de correta aplicação de um método fundado em certos saberes. Como já dissemos, esse pressuposto familiar aos cursos de formação docente é, por excelência, o emblema do baconismo na educação e o exemplo maior da visão tecnológica da escola. Ao que parece, a obsessão metodológica das administrações educacionais e de seus cursos de atualização docente é vista por Azanha como um entrave a encaminhamentos mais interessantes para as alegadas dificuldades do ensino democratizado. É o que tentaremos demonstrar mais adiante. Antes, porém, devemos esclarecer a ideia de ensinar como aplicar um método. 


\subsection{Uma questão de método?}

Voltemos então à ideia de melhorar o ensino pela introdução de novas tecnologias ou "métodos" pressuposta na modalidade de cursos criticada por Azanha. Preliminarmente é importante observar que não encontraremos uma definição rigorosa da expressão "método de ensino" na obra de nosso autor. Na verdade, a própria possibilidade da definição do que seria $o$ "método científico", inspirador do projeto didático comeniano, apresenta grandes embaraços. Em Uma ideia de pesquisa educacional, por exemplo, Azanha mostra as dificuldades da afirmação da existência de um método específico válido para o conjunto da produção científica e autônomo em relação à destreza particular do pesquisador. Não obstante essas ressalvas, Azanha reconhece que a expressão "método" tem sido usada no discurso científico desde o século XVII para designar um "conjunto de regras" capaz de conduzir com êxito a atividade do cientista (2011, pp.168-9). Embora tenhamos consciência da multiplicidade de sentidos possíveis do conceito de "regra", esse uso de "método" parece também pressuposto na descrição de ensinar como seguir um método tão questionada por Azanha. Nesses termos, quando discutimos as críticas do autor à ideia de "método de ensino", referimo-nos a um conjunto presumido de regras ou princípios relativamente independente da maior ou menor habilidade particular de um professor e capaz de garantir ou ao menos facilitar o êxito do ensino. Segundo essa definição, o estilo característico de um bom professor poderia ser codificado num conjunto de regras ou princípios na forma de proposições ou recomendações virtualmente generalizáveis para outras situações educacionais e igualmente aplicáveis por outros professores.

A bem da verdade, essa definição de "método" ou de "metodologia do ensino" pode soar bastante restritiva e até mesmo caricatural nos dias atuais. O próprio Azanha, na realidade, tinha clareza de que muitas vezes os formadores de professores ou os programas de formação usavam essas expressões num sentido bem menos rigoroso que aquele sugerido pela analogia com a ideia de "método" científico presente na obra de Comênio no século XVII. Como ele observa num texto sobre formação de professores,

Quando Comênio falava em método de ensino era no sentido claro e forte de uma transposição para a educação da concepção baconiana de método científico. [...] Nos últimos tempos, essa vinculação direta entre método de conhecimento e método de ensino teve o seu significado original substituído por uma pletora de metáforas sobre conhecimento das quais se fazem enigmáticas ilações sobre o ensino. (AZANHA, 2006, p. 55) 
Apesar da variação do sentido de "método" no discurso pedagógico observada pelo autor, não é preciso muito esforço para notar que, por mais flexível que seja, a noção de método ou metodologia de ensino pressupõe a aplicação, à situação de ensino, de um conjunto de princípios ou proposições práticas fundadas em algum saber teórico como forma de orientar a intervenção do educador. No comentário mordaz de Azanha, a "pletora de metáforas sobre conhecimento" representa a gama de saberes teóricos obtidos em algum ramo da pesquisa educacional - a psicologia cognitiva, por exemplo - que, por meio de "enigmáticas ilações", pretende orientar a atividade de quem ensina. No fundo, tal transposição do conhecimento teórico ou científico sobre a educação para regras práticas de ensino é a ideia tacitamente pressuposta no conceito de método que Azanha procura combater. Nesse particular, não faz muita diferença se o método de que se fala apresenta ou não a conotação "forte" fixada por Comênio. O ponto essencial é que os programas metodológicos de formação de professores pressupõem, de maneira mais ou menos esquemática, mais ou menos sofisticada, a possibilidade de que saberes teóricos gerais sobre a relação pedagógica, a criança ou a comunidade escolar possam servir de orientações práticas específicas para a atividade de ensinar ${ }^{41}$. É isso que Azanha tem em mente ao resumir a visão tecnológica do ensino como a "aplicação competente de um saber metodológico, epistemologicamente fundado em outros saberes" (2006, p. 56).

Ora, é justamente essa visão tecnológica do ensino que Azanha procura problematizar em seus escritos sobre o assunto, como Uma reflexão sobre a Didática (1987). No texto, o autor descreve esse campo de estudos educacionais como "um empreendimento muito semelhante àquele concebido por Comênio na Didática Magna" (1987, p. 72, grifos do autor). Segundo sua justificativa, "qualquer que seja o modo pelo qual se conceba, hoje, o conteúdo dos estudos didáticos", esse "modo tem como núcleo de preocupações" o propósito de "organizar o ensino em termos de viabilização do processo de aprendizagem". Desse modo, o "sonho de Comênio" de inventar a "arte universal de ensinar tudo a todos" continuaria "amplamente disseminado" nos estudos didáticos (1987, p.72). De acordo com Azanha, o empreendimento comeniano e suas variações históricas apresentam dois pressupostos altamente discutíveis, originados na crença baconiana no poder do método.

\footnotetext{
${ }^{41}$ Essa ideia é expressa de maneira clara em Comênio: "E se qualquer organista executa habilmente qualquer música escrita na partitura, apesar de não ser capaz de compô-la nem de executá-la de cor com a voz ou o órgão, por que não poderá o mestre ensinar qualquer coisa, se já encontrará prontas, como se impressas numa partitura, as coisas que deverão ser ensinadas e o modo de fazêe-las?" (2011, p. 363, grifos nossos). A "partitura" é obviamente sua Didática Magna.
} 
Esses pressupostos referem-se à interpretação equivocada da relação entre certos saberes sobre o ensino e a própria prática de ensinar, equívoco característico das tecnologias educacionais correntemente oferecidas nos cursos de formação de professores.

O primeiro pressuposto é justamente o que postula a existência de um "método de ensino", isto é, a "disponibilidade de um conjunto de regras" explícitas a respeito do ensino (1987, p. 74). Para Azanha, essa pressuposição é reveladora de uma confusão acerca da relação entre a atividade de ensinar e as suas possíveis regras. Sua argumentação indica que tal confusão baseia-se na transposição, para o âmbito do ensino, da necessidade de observância de regras prévias em outros campos da atividade humana. Em outras palavras, trata-se de imaginar que o êxito da atividade de ensinar, a exemplo de certas atividades, dependa necessariamente do conhecimento prévio e da observância de certas regras - isto é, envolve a posse a observância de um método.

O recurso utilizado por Azanha para desfazer essa má interpretação é a análise comparativa da "gramática lógica" do termo "saber" aplicado a diferentes atividades, entre as quais a atividade de ensinar. Esse tipo de investigação da gramática do uso das expressões é inspirado, entre outros, nos trabalhos de Gilbert Ryle (2009). Em linhas gerais, trata-se de verificar comparativamente no uso de expressões como "saber ensinar", "saber nadar", "saber jogar xadrez", etc., se o conhecimento prévio de regras na forma de máximas ou proposições (saber que tal coisa é o caso) é condição para a execução da atividade (saber como realizar tal atividade). A ideia, evidentemente, é perceber se a atividade de ensinar envolve a obediência a um método, isto é, um conjunto de regras ou princípios codificáveis na forma de proposições, de um "saber que".

Vejamos alguns exemplos retirados da amostragem de casos analisadas pelo próprio autor. O uso do verbo "saber" nas expressões "saber jogar xadrez", "saber nadar" e "saber argumentar" pressupõe diferentes relações lógicas entre essas atividades e o saber - ou o conhecimento - das possíveis regras que orientam a atividade ou que constituem critérios para a avaliação do êxito de sua execução. Em cada um desses usos, o termo "saber", em sua gramática lógica, prevê ou não a obediência a certas regras como condição da realização da atividade.

Por exemplo, quando dizemos que alguém "sabe jogar xadrez", queremos indicar que alguém conhece as regras do jogo e é capaz de aplicá-las com maior ou menor perícia. Saber jogar xadrez necessariamente implica que se conheçam as regras do jogo - o movimento do cavalo, por exemplo - e que a técnica de sua aplicação seja mais ou menos familiar ao 
jogador. Nesse sentido, só é possível jogar xadrez se soubermos que (knowing that) o cavalo se movimenta em Le soubermos realizar tal movimento nos momentos oportunos da partida. Não é possível jogar xadrez sem saber que tal e tal são regras que balizam os movimentos possíveis das peças e sem dominar a aplicação dessas regras. Jogando bem ou mal, um jogador de xadrez necessariamente sabe quais são as regras do jogo. Nas palavras de Azanha, jogar xadrez é um caso de "uma atividade cuja prática é, logicamente, precedida de um conhecimento [na forma proposicional, um "saber que"]" (AZANHA, 1987, p. 74, grifos do autor).

Este não é o caso, por exemplo, de "saber nadar". É bem possível que alguém saiba nadar sem saber que tal e tal são regras explícitas que promovem o bom desempenho do nadador profissional. Não é preciso conhecer as regras da fisiologia do corpo ou mesmo da natação para que se saiba nadar. Isso porque saber nadar é uma atividade, um saber fazer (knowing how), e o conhecimento de suas possíveis regras explícitas não é condição para a execução satisfatória. Quando se diz que alguém sabe nadar, referimo-nos a alguém que sabe como nadar, bem ou mal, pouco importando se o nadador sabe ou não que determinados movimentos impulsionam seu corpo na água. Na verdade, é bem possível que alguém tenha essas informações mas não saiba nadar. Como conclui Azanha, "nadar significa uma capacidade de executar uma atividade que pode ocorrer sem o conhecimento explícito de quaisquer regras" (AZANHA, 1987, p. 75). As regras, nesse caso, são incorporadas ao movimento do nadador, embora seu conhecimento explícito não seja condição necessária à realização da atividade.

Por fim, há práticas como "saber argumentar", cuja relação entre a atividade e suas possíveis regras é ainda mais complexa. Assim como "saber pensar criticamente", "saber argumentar" representa também uma atividade (knowing how), não um tipo de conhecimento proposicional, um "saber que" (knowing that). É claro que possuir algumas informações sobre a matéria em discussão ou sobre as regras explícitas da retórica (saber que tal e tal coisa é o caso) pode ajudar a avaliar se alguém argumenta bem ou não. No entanto, o conhecimento dessas regras não é suficiente para que alguém argumente bem - ou pense criticamente. Essas atividades, na verdade, são essencialmente criativas e, como nos lembra Azanha, "não há método para inventar" (1987, p. 75). Nesse caso, o estilo característico de um bom orador ou de um bom humorista não pode ser codificado num conjunto de proposições ou máximas universais capazes de assegurar idêntico resultado na atividade de outro praticante. Saber argumentar, portanto, é uma atividade, um saber fazer cujo êxito não 
depende do conhecimento prévio de quaisquer regras gerais. Além disso, nessa categoria de atividades, o verbo "saber" implica o êxito da atividade. Dizer que alguém sabe pensar criticamente ou sabe argumentar significa que ele o faz a contento. Não faz sentido dizer que alguém sabe argumentar, mas que argumenta mal. "Saber argumentar" é saber argumentar com êxito.

Não precisamos nos deter por mais tempo nessa discussão. Já deve estar claro a esta altura que, para Azanha, ensinar é essencialmente um tipo de atividade, um saber fazer (knowing how). No exemplário apresentado pelo autor, a atividade de ensinar "é muito mais semelhante às de pensar criticamente e de contar piadas do que às de jogar xadrez ou nadar" (1987, p. 76). Em outras palavras, "trata-se antes de um saber fazer do que de conhecer certas regras e aplicá-las. Se dissermos que alguém sabe ensinar, isto significa necessariamente que obtém êxito no seu propósito e só acessória e eventualmente que segue esta ou aquela regra" (1987, p.76). Nesses termos, não faz sentido esperar socorro de um "método de ensino" que assegure o êxito do professor. A afirmação da possibilidade de formulação de um código de recomendações e diretrizes que regulem o ensino é, na verdade, bastante problemática nos termos da análise lógica empreendida pelo autor.

Esses problemas mostram-se ainda com maior clareza na discussão do segundo pressuposto identificado por Azanha nos discursos didáticos. Trata-se do pressuposto de que a atividade de ensinar seja exaustivamente regulável, pressuposição, aliás, relacionada com a ideia de método. A noção de atividade exaustivamente regulável é emprestada por Azanha de Scheffler. Segundo a interpretação de Azanha, "dizer que uma atividade é exaustivamente regulável significa dizer que é possível, em relação a ela, explicitar um conjunto tal de regras que, se forem obedecidas, a atividade se completa com êxito" (1987, p.76). A fabricação de objetos como uma mesa pode ser considerada um exemplo emblemático dessa categoria de atividades. Embora cada artesão ou corporação de ofício medieval realizasse essa operação de maneira característica, o processo de produção de uma mesa ou de outro artefato similar pode ser apresentado na forma de um conjunto de regras que, se devidamente seguidas, garantem o êxito da fabricação. É claro que muitas vezes essas regras não precisam ser explicitadas para aqueles iniciados na prática de produção artesanal da mesa. Os movimentos desses artesãos experimentados já corporificam a obediência das regras sem a necessidade de sua explicitação. Isso, no entanto, não quer dizer que não seja possível, se necessário, codificar seus procedimentos exitosos num esquema geral transmissível a outros artesãos menos experientes. É igualmente certo que os novos aprendizes podem apresentar 
dificuldades na realização de suas primeiras mesas. Tais dificuldades entretanto têm a ver com problemas na obediência da regra, não com a possibilidade de sua formulação explícita. A aplicação correta das recomendações gerais do mestre artesão será devidamente burilada pelo tempo e pela prática do ofício, isto é, pela familiaridade com os procedimentos de aplicação específica das regras gerais apresentadas previamente. Dizer que a fabricação da mesa é uma atividade exaustivamente regulável não é o mesmo que dizer que qualquer um conseguirá aplicar competentemente as regras de fabricação da mesa. Essa definição simplesmente indica que, por princípio, é possível traduzir a atividade do bom artesão num conjunto de regras gerais transmissível àqueles que devem ser iniciados na sua correta aplicação. Transposta para o ensino, essa formulação corresponde à ideia de que é possível extrair da atividade do ensino, à maneira de Comênio, um conjunto de regras ou princípios que, se seguidos estritamente, garantem o sucesso dos esforços do professor.

À luz das ponderações sobre o tipo de relação entre a prática de ensinar e suas possíveis regras expostas há pouco, não é difícil perceber que, para Azanha, o ensino não é um exemplo de atividade exaustivamente regulável. Por se tratar de uma atividade "essencialmente criativa", a codificação e transmissão de regras e princípios generalizáveis a propósito do bom ensino é altamente problemática. Com efeito, não é difícil imaginar dois excelentes professores de uma mesma disciplina escolar que exibam estilos completamente diferentes de atuação e que, no entanto, obtenham êxitos semelhantes em sua atividade. Nesse caso hipotético, não há como reduzir os desempenhos publicamente muito distintos de um e outro a uma mesma regra ou princípio de atuação oculto - por exemplo, uma competência professoral. Trata-se antes de dois professores que "sabem ensinar" - ou seja, ensinam com êxito - embora sigam em sua prática regras completamente distintas e dificilmente traduzíveis na forma universal de um "saber que" explícito a ser difundido em curso gerais de formação continuada para seus colegas de profissão.

Todas essas considerações de Azanha comprometem as expectativas dos cursos de aperfeiçoamento docente de regular práticas escolares por meio da divulgação de novos métodos eventualmente fundamentados em novas descobertas a respeito da criança, da aprendizagem ou de qualquer outro tópico em moda. As ressalvas do autor são numerosas o bastante para que se suponha, sem maiores senões, a possibilidade de derivação de práticas escolares - ou seja, de atividades do tipo "saber fazer" - de conhecimentos teóricos acerca do fenômeno educativo - isto é, um saber proposicional do tipo "saber que". Há, contudo, um problema adicional nesse desiderato que apenas referimos de passagem. Trata-se da ideia 
de que a eventual comprovação da cientificidade de determinado conhecimento de um ramo da pesquisa educacional ou das ciências humanas sirva de fundamento suficiente para a formulação de práticas escolares correspondentes, independentemente dos programas práticos que tal conhecimento pode veicular ${ }^{42}$. Dito de outro modo, a validação científica de um conhecimento a respeito da prática educativa não significa, para Azanha, a necessidade de adesão imediata às possíveis práticas que tal conhecimento pode informar.

Em outro texto sobre a formação de professores, Uma reflexão sobre a formação do professor da escola básica (2006), Azanha transcreve um comentário de Scheffler que ilustra bem as dificuldades da transposição automática de conhecimentos de uma ciência ou da reflexão filosófica para o campo das práticas educativas. Diz Scheffler:

\begin{abstract}
Observamos que as definições científicas estão em continuidade com as teorias e com as evidências próprias aos seus domínios respectivos, e que o melhor, portanto, é que sejam tratadas à parte.[...] Elas devem ser julgadas, grosso modo, pela contribuição que fazem à adequação de suas respectivas redes científicas com relação à explicação dos fatos. Segue-se daí que adotar uma definição científica para uso programático não significa evitar a necessidade de avaliação do programa que esse uso veicula. A adequação científica de uma definição não é um signo do valor prático de tal programa (SCHEFFLER, 1974, p. 45)
\end{abstract}

Tomemos um exemplo para esclarecer as precauções recomendadas por Scheffler nessa passagem e endossadas por Azanha em seus escritos sobre o assunto. Os cursos de aperfeiçoamento docente em geral apresentam as virtudes de novas tecnologias educacionais como resultados de novas descobertas científicas sobre aspectos do processo educativo. Por exemplo, há não muito tempo, recomendações de novos procedimentos de alfabetização foram deduzidas de afirmações psicológicas ou de outra natureza a respeito das "hipóteses de escrita" que o aluno em fase de alfabetização supostamente formula ao entrar em contato com a cultura letrada ${ }^{43}$. Antigos professores acostumados a rotinas de

\footnotetext{
${ }^{42}$ Sobre a noção de definição ou conceito programático em Scheffler, ver p. 19 e seguintes do primeiro capítulo deste trabalho.

${ }^{43}$ Referimo-nos aqui, de maneira reconhecidamente grosseira, às tentativas de instrumentalização das ideias de, entre outros, FERREIRO, Emília. Psicogênese da língua escrita. Porto Alegre: Artmed, 1999. Mantivemos o exemplo, ainda que caricatural, para esclarecer o ponto em questão. Uma ideia das recomendações didáticas auferidas das afirmações psicolinguísticas pode ser encontrada na seguinte reportagem de uma revista destinada aos professores da educação básica: http://revistaescola.abril.com.br/lingua-portuguesa/alfabetizacaoinicial/conhecer-nova-turma-431205.shtml. De acordo com a publicação, "É por não levar em conta o ponto mais importante da alfabetização que os métodos tradicionais insistem em introduzir os alunos à leitura com palavras aparentemente simples e sonoras (como babá, bebê, papa), mas que, do ponto de vista da assimilação das crianças, simplesmente não se ligam a nada. Segundo o mesmo raciocínio equivocado, o contato da criança com a organização da escrita é adiado para quando ela já for capaz de ler as palavras isoladas, embora as relações que ela estabelece com os textos inteiros sejam enriquecedoras desde $o$ início. Segundo Emilia Ferreiro, a alfabetização também é uma forma de se apropriar das funções sociais da escrita.
} 
alfabetização já sedimentadas na cultura escolar viram-se diante do imperativo de reformular suas formas habituais de trabalho a fim de considerar as hipóteses de escrita da criança alegadamente descobertas pela pesquisa pedagógica. Assim, a prática dos exercícios de repetição de sílabas ou a decoração da correspondência entre signos e fonemas da língua falada foram rechaçadas como expressivas do autoritarismo docente e do desrespeito do alfabetizador pelas "hipóteses" próprias da criança.

Ora, pode ser que, consideradas "em continuidade com as teorias e com as evidências próprias aos seus domínios respectivos", as afirmações acerca das hipóteses de escrita sejam completamente válidas e inclusive úteis para o esclarecimento de aspectos da alfabetização do ponto de vista psicológico ou de outro ramo da pesquisa teórica sobre a educação. $\mathrm{O}$ grande problema, típico do viés metodológico dos cursos criticados por Azanha, é a adesão irrefletida a determinadas sugestões de práticas escolares pelo simples fato de elas supostamente derivarem de uma teoria considerada como a última palavra científica sobre o assunto. No caso invocado no exemplo, os possíveis "programas práticos" ligados às definições teóricas sobre a alfabetização exigiriam consideração independente na visão de Azanha. Dito de outro modo, ainda que uma investigação empírica chegue à conclusão, referenda pela comunidade cientifica própria, de que a alfabetização eficiente relaciona-se com as hipóteses de escrita apresentadas pela criança, tal correlação não é suficiente para a imposição às escolas de avaliações diagnósticas dessas hipóteses ou de qualquer outro procedimento didático daí derivado. A avaliação da pertinência científica de uma proposição pedagógica não coincide com a avaliação da pertinência programática de seus possíveis desdobramentos práticos. A avaliação do programa prático de uma definição ou de um princípio pedagógico requer considerações próprias. Essas considerações têm a ver com critérios propriamente educativos - frequentemente de natureza deontológica - relacionados à conveniência da adoção de certos desdobramentos pedagógicos das afirmações em questão. Essa exigência confere aos professores e à comunidade escolar o papel de julgar suas escolhas pedagógicas também em termos éticos. Nas palavras de Azanha:

De acordo com suas conclusões, desempenhos díspares apresentados por crianças de classes sociais diferentes na alfabetização não revelam capacidades desiguais, mas o acesso maior ou menor a textos lidos e escritos desde os primeiros anos de vida."

Para um tratamento adequado dos problemas desse tipo de transposição, ver CARVALHO. José Sérgio Fonseca de. Construtivismo: uma pedagogia esquecida da escola. Porto alegre: Artmed, 2001. 


\begin{abstract}
Mesmo naqueles casos em que reiteradas comprovações empíricas parecem dar sustentação e credibilidade a algumas teorias ou hipóteses científicas, permanece a questão propriamente educacional de saber se uma determinada atuação pedagógica deve ser posta em prática apenas porque teria algum respaldo científico.[...] Enfim, a validade científica de uma teoria não constitui base suficiente para a formulação de diretrizes educativas que sempre exigem opções entre valores (AZANHA, 2006, p. 57)
\end{abstract}

Um exemplo bastante ilustrativo da exigência de opção entre valores evocado por Azanha é o da educação sexual, que, em suas palavras, “jamais poderá ser conduzida a partir apenas de informações sobre desenvolvimento e fisiologia do sexo" (2006, p. 57). Porém, se prestarmos atenção, mesmo o caso da alfabetização não se resume à fria escolha entre procedimentos mais ou menos amparados cientificamente. Os execrados exercícios de repetição de sílabas não podem ser igualmente vistos como uma prática eficiente de iniciação à cultura letrada daqueles que não tiveram tantas oportunidades de formular "hipóteses de escrita" no ambiente doméstico?

Até o momento, nada mais fizemos senão apresentar as críticas de Azanha aos pressupostos dos cursos de formação de professores inspirados numa visão tecnológica do ensino que remonta à tradição pedagógica baconista iniciada pelos trabalhos de Comênio. Todavia, afirmamos logo no começo deste capítulo que era nosso objetivo mostrar que o uso programático de "autonomia da escola" por Azanha procurava oferecer referências alternativas à melhoria da qualidade do ensino público que fizessem frente às tentações metodológicas do aperfeiçoamento docente das administrações escolares. Resta então responder à pergunta: o que as muitas suspeitas de Azanha a propósito da ênfase metodológica desses cursos pode ter a ver com sua defesa da autonomia da escola? A formulação de respostas satisfatórias a essa pergunta não é simples. Não obstante, a consideração preliminar da noção de vida escolar parece incontornável a qualquer esforço nesse sentido.

\title{
3.3. Do professor abstrato à vida escolar
}

Como já observamos, a descrição do ensino como a aplicação de um método pressupõe uma relação pedagógica entre um professor e um grupo de alunos. Embora Azanha reconheça que a visão tecnológica do ensino de linhagem baconista corresponda à pretensão mais ambiciosa de aplicar princípios científicos à educação em geral, a ideia de 
método frequentemente diz respeito à situação em que um professor procura instruir um aluno ou um grupo de alunos. De fato, a imagem "do professor" abstraído do contexto institucional domina as recomendações de novas metodologias de ensino. Na verdade, a proposta de melhorar o ensino por meio da difusão de novos métodos dirige-se a esse professor - a quem cabe pôr em prática as tecnologias educacionais - como se ele fosse um indivíduo isolado de seu entorno institucional.

Nesse sentido, a visão tecnológica do ensino é solidária da descrição da relação pedagógica como uma preceptoria definida pela interação entre o professor que ensina e o aluno que aprende, discutida no capítulo 2. No fundo, a postulação da existência de um conjunto de regras explícitas presumidamente generalizáveis a respeito do ensino depende da suposição de que um professor abstrato é o possuidor de um saber metodológico mais ou menos autônomo em relação às condições institucionais e às idiossincrasias de sua experiência docente. Por princípio, um método no sentido aqui adotado é adquirível por qualquer professor em qualquer situação educacional - e muitas vezes a despeito dela. É uma recomendação destinada ao professor em geral.

Essa marca abstrata do reformismo metodológico é notada por Azanha num comentário a respeito das propostas de formação de professores da educação básica em cursos de licenciatura. Diz ele:

\footnotetext{
Outra crítica muito grave que se pode fazer às diferentes propostas de bases teóricas da formação docente está na unanimidade que apresentam ao focalizar a figura individual do professor. Traçar o perfil profissional do professor, detentor de determinadas competências cognitivas e docentes, é um exercício pedagógico para esboçar um "retrato imaginado" do que seria o professor universal. Esse exercício seria tão útil para a educação quanto a descrição do "espírito científico" para a ciência (AZANHA, 2006, p. 58)
}

O comentário chama a atenção para a tendência dos cursos de licenciatura de esboçar um ideal de "professor universal" como referência para a formação dos licenciandos. Nessa perspectiva, os programas de formação docente são balizados por uma gama imaginada de saberes e competências profissionais necessários ao professor em geral, em abstração do contexto institucional concreto da escola onde deve simplesmente aplicá-los. Um exemplo elucidativo dessa tendência de formação talvez seja a proposta do Instituto Nacional de Estudos Pedagógicos (INEP) de Referenciais para o exame nacional de ingresso na 
carreira docente, submetida recentemente à consulta pública ${ }^{44}$. Não se pretende aqui discutir a conveniência do estabelecimento de uma carreira ou de exames de ingresso à carreira docente em nível nacional. A referência ao documento se justifica pelo arrolamento que faz das características que definiriam “o perfil de um bom professor” (INEP, 2010). Segundo a proposta, o bom professor

2. Conhece as características de desenvolvimento dos alunos, suas experiências e contexto em que vivem, e como esses fatores afetam sua aprendizagem.

3. Domina a didática das disciplinas que ensina, incluindo diversas estratégias e atividades de ensino. [...]

5. Organiza os objetivos e conteúdos de maneira coerente com o currículo, os momentos de desenvolvimento dos alunos e seu nível de aprendizagem. (INEP, 2010)

Sem pôr em questão a correção dessas formulações abstratas na descrição do professor desejável, o texto deixa claro que o bom ensino é imaginado como a mera aplicação de um repositório de competências por um professor genérico. No caso do item 2, esse professor é descrito como alguém que possui um conhecimento teórico a respeito do ensino e deve ser capaz de aplicar os procedimentos correspondentes em quaisquer circunstâncias educativas: por saber qual é o contexto do aluno ele deve saber como promover sua aprendizagem. Já no item 3, a referência, ainda que discreta, à ideia de método de ensino aparece na associação entre as estratégias de ensino e a "didática da disciplina". Nesses termos, pressupõe-se que cada disciplina escolar possua um conjunto específico de regras explícitas que deve orientar a atuação desse professor abstrato, sem as quais o resultado do ensino é presumivelmente prejudicado. Essa última pressuposição, aliás, era bastante familiar aos cursos de formação continuada de professores. Azanha refere-se a ela em um de seus textos sobre o assunto nos seguintes termos:

\footnotetext{
Não vejo sentido, por exemplo, em reunir cem, duzentos, quinhentos professores de matemática e ensinar-lhes novas técnicas de ensino de matemática. Aqueles quinhentos professores de matemática não têm muita coisa em comum, a não ser o título de professor de matemática. O ensino de matemática da escola A é diferente do ensino de matemática da escola B, da escola C, D, E ou F. [...] O ensino não depende da eficiência de uma metodologia de um professor [...] (AZANHA, 1995, p. 25)
}

Diante de todas essas objeções enérgicas, pode-se se pensar que nosso autor seja contrário à qualquer iniciativa de preparação individualizada do professor num curso de

\footnotetext{
${ }^{44}$ Disponível em http://consultaexamedocente.inep.gov.br/index/login. Acessado em 10/01/2016.
} 
licenciatura ou ainda que deseje banir por completo, nesse tipo de formação ou nos cursos de aperfeiçoamento docente, o estudo de teorias pedagógicas ou didáticas. Essa conclusão, contudo, não é correta. Por que, então, Azanha apresenta restrições tão recorrentes à ideia de formar "o professor" em teorias e métodos sobre o ensino? A resposta a essa pergunta, na verdade, representa uma primeira aproximação do ponto de maior interesse nesta parte do trabalho, a saber, as possíveis relações entre a oposição de Azanha às tecnologias educacionais e sua defesa da autonomia da escola.

O ponto fundamental é que, para o autor, essas propostas de formação ou aperfeiçoamento do professor abstrato, isolado do contexto institucional da escola, representam descaminhos a esforços mais interessantes no encaminhamento das dificuldades verificadas na escola pública democratizada. Aos olhos de Azanha, a obsessão baconista alardeada pelas administrações educacionais de reformar o ensino por meio da difusão de novos métodos obscurecia a percepção dos problemas específicos da nova situação educacional, problemas esses que transcendiam as estreitas questões de método. Nas palavras do autor,

\begin{abstract}
A maciça expansão das matrículas no ensino fundamental desde há trinta anos, e no ensino médio mais recentemente, inviabilizaram uma concepção da atividade do ensino fundada na relação professor-aluno, na qual a imagem do "bom professor" era basicamente a daquele profissional que dominava um saber disciplinar que seria transmitido a um discípulo. O êxito desse ensino dependia pensava-se - de uma combinação do conhecimento disciplinar e do preparo didático do professor. [...]

Hoje, porém, a grande expansão do ensino fundamental deu origem a um tipo de escola que é uma novidade institucional, na qual as relações pedagógicas possíveis não podem ser modelados a partir apenas de métodos e procedimentos de alguém que ensina e de habilidades, competências e qualidades psicológicas de alguém que aprende. (AZANHA, 2006, pp. 58-61)
\end{abstract}

Nos termos de Azanha, o modelo preceptorial de formação docente, como já referimos no capítulo anterior, é uma forma de descrição do desempenho do professor correlata às formas do antigo ginásio de conceber a vida escolar. Não se trata, por conseguinte, de um modelo válido para quaisquer circunstâncias educativas ou para o professor em geral. Desse modo, além das restrições já discutidas acima, a definição do ensino como a aplicação de um método por um professor abstrato é problemática também por não corresponder às relações pedagógicas possíveis na nova instituição escolar. A qualidade do ensino dessa novidade institucional não pode ser melhorada pela insistência anacrônica em municiar "o professor" com novos métodos e tecnologias educacionais. 
A alternativa apresentada por Azanha para o tratamento das eventuais dificuldades encontradas nas escolas é a consideração da vida escolar ou do mundo escolar (2006, p. 103). Esse conceito, como sugerem ambas as versões, enfatiza a relevância da cultura institucional de cada escola na consideração até mesmo do desempenho individual do professor. Em coerência com a centralidade da vida escolar, Azanha costumava citar nas discussões sobre formação de professores uma frase de Gusdorf segundo a qual o "professor de latim" - ou de qualquer outra disciplina particular - deveria compreender que, antes ser professor de latim, "era professor" (2006, p. 100). Com essa referência, Azanha pretendia destacar, em contraste com a noção do professor abstrato regulado por um método, os vínculos de pertencimento desse profissional à cultura singular de cada escola. Não por acaso, dizia ele, um licenciado habilitado em uma determinada disciplina não é propriamente um professor até ingressar numa escola: "diferentemente de outras situações profissionais, o exercício da profissão de ensinar só é possível no quadro institucional da escola" (2006, p. 63). Nesses termos, não pode haver o professor em geral, mas apenas um professor de uma dada escola. Nas palavras de Azanha, a "relação educativa" sempre acontece "na sala de aula, que, por sua vez, integra-se numa escola"; "o chamado processo ensino/aprendizagem" é "uma abstração" (2006, p. 97)

Se voltarmos novamente nossa atenção ao excerto transcrito acima a propósito das diferenças entre o ensino de matemática nas escolas A, B, C, etc., os vínculos entre o desempenho do professor e o contexto particular da escola esclarecem por que seria inócuo transmitir métodos de educação matemática em geral. É inegável que o conhecimento da disciplina e de saberes metodológicos pode eventualmente contribuir para o ensino de matemática numa determinada escola. O que Azanha pretende ressaltar, entretanto, é que mesmo o êxito do ensino de uma disciplina particular, a cargo de um professor individual, depende antes de elementos da cultura escolar não previstos pelo saber codificado em teorias pedagógicas ou tecnologias educacionais abstratas. Por esse motivo, uma das linhas de investigação propostas por Azanha no programa de pesquisas desenhado em Cultura escolar brasileira é justamente a investigação do "saber escolar":

\footnotetext{
O ensino seria invariavelmente uma malogro se não fosse a existência no âmbito da escola de um "saber" não codificado nem expresso numa linguagem teórica mas que, no fundo, constitui a base da atuação docente. Na verdade, a formação do professor e o seu próprio aperfeiçoamento completam-se com o êxito que ele tenha na assimilação desse saber difuso e historicamente sedimentado no ambiente escolar e que tem apenas tênues relações com teorias pedagógicas. (AZANHA, 1995, p. 76)
} 
Nessas condições, mesmo o êxito da atuação individual de um professor de matemática no contexto de uma sala de aula depende de saberes e rotinas próprias da instituição escolar. Embora não codificado - e talvez não codificável - em regras explícitas e não fundamentado em teorias pedagógicas na forma de um "saber que" - a exemplo das competências docentes -, esses artifícios propriamente escolares de ensino constituem a "base da atuação docente". Trata-se antes de um repertório de práticas, de "saberes como" (knowing how), correlatos às rotinas cotidianas de cada escola. Por esse motivo, a divulgação de novos procedimentos abstratos de ensino é, para o autor, um recurso pouco interessante mesmo para a melhoria do desempenho individual do professor:

[...] A melhoria de qualquer prática (inclusive da docente) é fruto da aquisição de um "saber que", isto é, de um saber proposicional? No fundo, essas questões dirigem nossa atenção para o problema essencial da didática. [...] Isso posto, a conclusão, quase inevitável, é que a melhoria da prática somente pode ser feita pela crítica da própria prática, no momento em que ela ocorre, e não pela crítica teórica de uma prática abstratamente descrita, ainda que essa descrição seja feita pelos próprios praticantes. (AZANHA, 1995, pp. 202-203)

O reconhecimento da centralidade dessas práticas, no entanto, não deve ser entendido como uma espécie de apologia de Azanha a tudo que se faz na escola pelo simples fato de se tratar de uma prática própria da escola. Basta lembrar que a reprovação nas séries iniciais do ensino primário ou do que corresponderia hoje às séries intermediárias do ensino fundamental de nove anos é um exemplo de prática escolar duramente condenada pelo autor (2006, pp.151-153). O ponto fundamental é que Azanha procura chamar a atenção para aspectos da escola - e principalmente da escola democratizada - solenemente ignorados até então pela pesquisa educacional, ora preocupada com a formulação de métodos ora desencaminhada pelo abstracionismo pedagógico. Não é outra razão que leva Azanha a insistir repetidas vezes na importância da revisão conceitual sobre o significado de escola e do ensino e na investigação das práticas escolares cotidianas (1995, pp.70-74; 2011, pp. 57 61).

Por exemplo, em Uma ideia de pesquisa educacional (2011), o autor chama a atenção para a importância do estudo das práticas escolares cotidianas como forma de evitar as descrições abstracionistas do que se passa na escola democratizada, a exemplo das discutidas no segundo capítulo deste trabalho. Apenas a título de ilustração, Azanha comenta que a atenção a aspectos corriqueiros do dia-a-dia das escolas poderia desfazer alguns 
equívocos das descrições abstracionistas da nova realidade escolar. Assim, uma perspectiva devidamente direcionada aos acontecimentos triviais da instituição deixaria claro o nonsense da tendência a menosprezar as diferenças significativas entre o "ensino" da escola antes e depois da democratização de seu acesso. Nas palavras de Azanha,

[...] a rápida expansão de vagas do $1^{\circ}$ grau afetou, não nas aparências nem na superfície, mas radicalmente as práticas escolares concretas de todos os dias, porque abriu a escola para uma imensa parcela da população dela até então afastada. Essa massa populacional escolar inviabilizou inteiramente anteriores padrões de ensino, de convivência humana, de relações escola-comunidade, etc. Instalou-se uma nova realidade educacional. É claro que é possível ignorar tudo isso como um movimento irrelevante na superfície das coisas e insistir que essencialmente tudo continua no mesmo. (AZANHA, 2011, p. 49)

Pelos termos do comentário, é possível perceber que Azanha põe em questão os argumentos dos estudos alegadamente materialistas segundo os quais as relações escolares seriam mero reflexo do contexto econômico e social. Desse ponto de vista abstrato, as relações educacionais não teriam sofrido mudanças significativas porque a estrutura social do período permanecia a mesma. O que interessa a Azanha é justamente destacar que essa conclusão só é possível se as profundas alterações ocorridas nas práticas diárias da escola básica passarem despercebidas pelas "grossas malhas da tipologia" (2011, p. 57). No entanto, um observador menos entusiasmado com esse tipo de operação abstracionista poderia reconhecer nessas sutis diferenças cotidianas indícios de diferenças significativas na totalidade do processo educativo e mesmo nas relações entre a escola e a sociedade na época em questão.

Nesses termos, o estudo das práticas cotidianas da escola é visto por Azanha como um ponto de vista interessante para descrições da vida escolar, presente ou passada. Não obstante sua fecundidade potencial, a vida que transcorre no dia-a-dia das escolas foi, a seu ver, quase completamente desprezada pela pesquisa educacional. Em Uma ideia de pesquisa educacional, o autor, a fim de destacar a ausência histórica de registro das práticas escolares cotidianas, formula uma série de questões que dá ideia da limitação do nosso conhecimento a respeito dessa dimensão da vida escolar:

Por exemplo, há sequências fixas nas atividades escolares ao longo do dia? Por que e como foram estabelecidas? O que se costumava fazer na primeira aula de alfabetização? Como se alfabetizava no final do Império? E há dez, vinte, quarenta anos atrás? Quais as diferenças que ocorreram ao longo dos anos? Como são feitas as reuniões pedagógicas? E o registro das atividades de ensino, como evoluiu de 1930 para cá? Etc. (AZANHA, 2011, p. 59) 
Obviamente, a ausência de registros que documentem a vida cotidiana torna inviável qualquer esforço sério de investigação das práticas escolares. Entretanto, a mera compilação de fatos cotidianos da escola não é suficiente para a formulação de descrições interessantes a respeito da vida escolar. Já observamos no capítulo 2 que a descrição densa de diferenças significativas com base em índicios captados no objeto descrito depende sobretudo de uma operação conceitual. Esse tipo de advertência, aliás, é uma das discussões mais importantes exploradas em Uma ideia de pesquisa educacional por Azanha. Esse assunto, porém, não é o tema de maior interesse nesta parte do trabalho. A alusão ao tema se justifica apenas porque oferece uma ideia ampla da complexidade e da relevância do estudo das práticas escolares cotidianas. Embora no trecho citado Azanha indique as limitações das pesquisas empíricas sobre o cotidiano escolar, não acreditamos exagerar ao dizer que os cursos de aperfeiçoamento destinados a divulgar novas tecnologias educacionais compartilham da presunção do pouco interesse representado pelo conhecimento das práticas cotidianas dos professores. Assim como as complicadas questões teóricas do estudo das práticas cotidianas podem ser banalizadas por pesquisas interessadas simplesmente em amontoar informações sobre o dia-a-dia das escolas, o substrato de "saber escolar" próprio da experiência docente pode eventualmente ser reduzido à condição de arcaísmo docente pelos difusores de novas tecnologias educacionais. Nesse sentido, não nos parece casual a observação de Azanha a respeito da ignorância dos proponentes desses cursos a respeito das práticas próprias da vida escolar:

\begin{abstract}
A eventual melhoria das práticas docentes exigiria um adequado conhecimento dessas próprias práticas e das condições em que elas ocorrem. E esse conhecimento raramente é disponível para os especialistas que ministram os cursos, simplesmente porque o assunto não tem sido objeto de pesquisas sistemáticas e continuadas. Como melhorar práticas que são desconhecidas? É claro que, em alguns casos, o longo tirocínio do especialista, que ministra o curso, poderá permitir suprir precariamente um inexistente conhecimento sistemático. Mas uma política de aperfeiçoamento docente não pode depender de tais eventualidades. (AZANHA, 1995, p. 202)
\end{abstract}

Tomemos um exemplo para mostrar como o descaso pelos acontecimentos banais da escolarização pode levar a descrições duvidosas das práticas docentes. Trata-se, na verdade, da variação de um exemplo referido anteriormente: as práticas de alfabetização. Em nossa primeira referência, dissemos que práticas escolares como os exercícios de decoração e repetição de sílabas propostos pelos professores primários podem eventualmente ser 
descritos como inibidores da expressão das "hipóteses de escrita" dos alunos. Essa mesma avaliação pode ser estendida para o uso da cartilha como livro-texto para esses exercícios típicos das rotinas de alfabetização. Sem discutir os problemas de conteúdo e de cunho ideológico desses afamados recursos didáticos, as cartilhas foram convertidas em verdadeiros ícones da prática professoral retrógrada e autoritária pelo discurso das novas tecnologias da alfabetização.

Entretanto, terá sido esse mesmo o uso dado à cartilha no contexto de uma aula de alfabetização? E, uma vez confirmado, as consequências reconhecidamente indesejáveis desse uso descritas pelos reformadores das práticas de alfabetização correspondiam ao observado em sala? O professor ou professora que alfabetizava seguia de fato uma ordem rigorosa a ponto de evitar a expressão das "hipóteses das crianças" sobre a formação das sílabas e a relação entre sons e signos? Como as crianças reagiam ao uso da cartilha? Essas reações expressavam de fato a intimidação esperada pelo professado autoritarismo docente? Enfim, essas e outras questões, mais ou menos informadas pelos apontamentos de Azanha, poderiam ser endereçadas aos formadores em novas tecnologias de alfabetização. Sua formulação, na verdade, põe em evidência a indiferença dos cursos de aperfeiçoamento referidos por Azanha em relação às práticas cotidianas dos professores, sendo elas boas ou más. Devido ao vácuo desse conhecimento acerca do "saber escolar", muitas das tecnologias da educação talvez procurem responder a problemas relacionados a "falsos objetos". É o caso do problema do suposto objeto "cartilha". Assim como no caso do problema do "professor", do "aluno" ou do "livro", mascaramos sob essa expressão, o que é fundamental: “o jogo das complexas relações sociais que ocorrem no processo institucional da educação". (AZANHA, 1995, p. 71)

Até aqui fizemos referência sobretudo às práticas de ensino próprias da vida escolar. Entretanto, a fim de evitar o desnecessário estreitamento do conceito, devemos lembrar que essa expressão era usada por Azanha num sentido mais abrangente que procurava compreender o conjunto de práticas escolares correlatas às dinâmicas cotidianas da instituição - dentro ou fora da sala de aula, por assim dizer. Para Azanha, a vida escolar extrapola o ensino e aprendizagem de disciplinas. Trata-se, na verdade, de uma cultura própria construída com o tempo pelas relações sociais que têm lugar na instituição. Embora essas relações girem em torno do ensino e da aprendizagem de matérias escolares, não se restringem a essas funções formais da instituição. É o que lemos nas seguintes definições expostas pelo autor: 
No âmbito das escolas transcorre uma vida social própria, específica, típica da natureza da instituição ensinante. Grande parte dessa vida social se desenvolve por meio de rotinas que são próprias da instituição. O conjunto das rotinas escolares é altamente complexo e nele é possível distinguir algumas que são estabelecidas por normas explícitas de origem externa ou interna. [...] Mesmo práticas rotinizadas por determinações claras de um regimento são afetadas por valores sociais, políticos, econômicos, pessoais que operam de modo claro ou sub-reptício no jogo das relações humanas que existem no âmbito de uma escola. (AZANHA, 1995, pp. 127-128)

A escola, ou melhor, o mundo escolar, é uma entidade coletiva, situada num certo contexto, com práticas, convicções, saberes que se entrelaçam numa história própria em permanente mudança. Esse mundo é um conjunto de vínculos sociais frutos da aceitação ou da rejeição a um multiplicidade de valores pessoais e sociais. (AZANHA, 2006, p. 103)

As definições da vida escolar ou do mundo escolar propostas por Azanha merecem especial atenção. Deixaremos as referências aos "valores", presentes em ambos os excertos, para adiante. Preliminarmente, devemos observar a recusa à redução do ensino à relação individualizada entre professores e alunos regulada por um método. Diferentemente dos entusiastas das tecnologias educacionais, nosso autor não abstrai a relação pedagógica ou o "processo de ensino/aprendizagem" da trama histórica de "vínculos" e "valores" característicos de uma escola. Com isso, Azanha não quer dizer que as práticas de ensino ou devam ser permeáveis a inclinações e costumes pessoais dos membros da comunidade escolar. Nada seria mais contrário ao republicanismo do autor. Trata-se simplesmente do fato de que, concretamente, o ensino não é a mera aplicação de um método por um professor competente. $\mathrm{O}$ desempenho do professor, de maneira talvez mais ampla do que o esperado, é condicionada pelas relações sociais manifestas no cotidiano da instituição.

Outro traço distintivo da escola é que ela sempre tem endereço e vizinhança, o que afeta profundamente a sua convivência social interna, muito além do que é possível ou desejável em outras instituições. Cada escola, mesmo quando integra um sistema, desenvolve uma comunhão espiritual a partir de seu enraizamento numa situação local (AZANHA, 2006, p. 64)

Ainda no primeiro capítulo deste trabalho, observamos que, na obra de Azanha, o uso programático da "autonomia da escola" sempre se associava à proposta de melhoria da qualidade do ensino nos termos de sua realidade local específica. Considerando agora a noção de escola e vida escolar expostas acima, é possível compreender a ênfase do autor nas diferenças locais apresentadas por cada instituição. Veremos oportunamente que essa perspectiva, possível graças à ideia de vida escolar, fundamentará a proposta de autonomia 
da escola de Azanha. Por ora, contudo, basta destacar que a constatação da importância do endereço e da vizinhança de uma escola é outra objeção grave às iniciativas de formação do professor para o ensino em geral ou às tentativas de reforma do ensino de uma rede inteira por meio de medidas padronizadas de melhoria de ensino.

Essa observação nos leva a outro reparo formulado por Azanha aos cursos de formação de professores. Embora suas advertências dirijam-se às iniciativas de aperfeiçoamento docente, elas não são estranhas aos pressupostos dos cursos de formação inicial de professores no âmbito das licenciaturas. Trata-se da ideia de que a preparação e a atualização individual do docente - ou mesmo do conjunto de docentes - de uma escola seja suficiente para a melhoria do ensino da escola. Não precisamos nos estender na discussão da primeira parte desse pressuposto, isto é, a de que a formação do professor individual, isolado do contexto institucional da escola, não garante a melhoria de seu desempenho, que é sempre dependente das complexas relações da vida escolar. Gostaríamos de nos deter na segunda parte do pressuposto: por que o aperfeiçoamento individual de todos os professores de uma mesma escola não garantiria a melhoria do ensino oferecido na instituição? Dito de outro modo, por que a atualização de todos os professores de uma unidade escolar em novas tecnologias didáticas não seria um caminho viável para a melhoria do ensino da instituição? É certo que, concretamente, essa ideia soa impraticável. Entretanto, em termos hipotéticos, não é razoável supor que a reunião de professores individuais competentes garanta a excelência do ensino da instituição?

Essa conclusão, na verdade, baseia-se numa confusão. Do mesmo modo que, segundo Azanha, a democracia não é a reunião de indivíduos democráticos - como vimos no primeiro capítulo -, uma escola não é simplesmente a reunião de um conjunto de professores. De acordo com as palavras do autor, uma escola é "mais do que a simples reunião de professores, diretor e outros profissionais" (2006, p. 103). Essa equiparação do corpo docente à ideia de escola é equivocada. A situação não se resolveria se essa identificação incluísse também os alunos, os funcionários em geral e a comunidade. Mesmo nesse caso persiste o erro de reduzir a vida escolar a um conjunto de comportamentos e escolhas individuais dos frequentadores momentâneos da escola.

No fundo, a escola, na definição de Azanha, é "uma unidade de outra ordem, é uma instituição" (1995, p.176). Por instituição, o autor não entende simplesmente uma coletividade que presta serviços educacionais a clientes de seu entorno. O termo aparentemente é usado no sentido forte de um "mundo" de práticas, rotinas, valores e 
experiências enraizados não apenas no espaço mas também no tempo. Nesse sentido, cada escola é - ou ao menos aspira a ser - uma instituição singular com um conjunto de práticas que transcende a passagem daqueles que temporariamente exercem o ofício docente nos seus quadros $^{45}$. Não é à toa que, em todas as definições da vida ou do mundo escolar transcritas acima, Azanha alude à dimensão temporal dos valores e práticas da instituição. Assumindo o risco da repetição desnecessária, vejamos mais uma caracterização de escola encontrada na obra de Azanha que evidencia sua dimensão histórica. Trata-se de uma definição extraída da obra de Oakeshott:

[...] a ideia de "escola" é de uma comunidade histórica de professores e alunos, nem muito grande nem muito pequena, com tradições próprias que dão origem a lealdades, obrigações e sentimentos dedicados a iniciar sucessivas gerações de recém-chegados à condição humana (Oakeshott, M. apud AZANHA, 2006, pp. 64-65)

Azanha não se estende no comentário da definição de Oakeshott. No entanto, não seria infundada a afirmação de que as "tradições próprias" de uma escola correspondem às tramas de relações sociais próprias da vida escolar. Trata-se assim de um "mundo" que se interpõe não apenas entre os professores e alunos atuais da instituição, mas igualmente entre as gerações que compõe essa "comunidade histórica" específica.

Nessas condições, Azanha não via muito sentido na insistência da melhoria do ensino por meio da formação individual dos professores, ainda que essa formação atingisse virtualmente a totalidade dos professores de uma escola. De fato, "o professor" ou "os professores" isolados são, na linguagem do autor, "falsos objetos", já que, no contexto institucional da escola, seu desempenho é condicionado por um antigo e complexo "jogo" não controlável pela otimização de seus respectivos lances parciais. A vida esscolar é marcada por rotinas, hábitos, princípios e valores que recuam no tempo. Não se pode

\footnotetext{
${ }^{45}$ A noção de instituição empregada por Azanha nessas discussões é provavelmente inspirada na obra $\mathbf{A}$ construção social da realidade, de Berger e Luckmann (1976). Em seus comentários sobre a noção de proposta pedagógica, Azanha se referia em particular à noção de "conhecimento primário" dos autores, isto é, o conjunto de saberes escolares que informam e tipificam as rotinas institucionais. Ver, por exemplo, AZANHA, 2006, pp.103-104. Na obra de Berger e Luckmann, encontramos as seguintes considerações sobre a ideia de instituição e sobre a importância da historicidade na sedimentação das práticas institucionais: "A institucionalização ocorre sempre que há uma tipificação recíproca de ações habituais por tipos de atores. [...] As tipificações das ações habituais que constituem as instituições são sempre partilhadas" (p.79). "Com a aquisição da historicidade estas formações adquirem também outra qualidade decisiva [...] a objetividade. Isto significa que as instituições que estão agora cristalizadas (por exemplo, a instituição da paternidade tal como é encontrada pelos filhos) são experimentadas como existindo por cima e além dos indivíduos que acontece 'corporificá-las' no momento. Em outras palavras, experimentam-se as instituições como se possuíssem realidade própria, realidade com a qual os indivíduos se defrontam na condição de fato exterior [...]” (p. 84).
} 
simplesmente fazer tábula rasa dessa intricada trama de relações sociais para dar lugar, a partir do nada, a novas tecnologias educacionais. Para Azanha, qualquer esforço de transformação das práticas escolares deveria levar em conta o pertencimento dos professores a esse universo de rotinas correlatas a valores e princípios que se manifestam no cotidiano da instituição.

Desse modo, a melhoria das práticas escolares não pode ser realizada pela melhoria da prática individual do professor, ainda que todos os professores de uma escola sejam atualizados em recentes tecnologias educacionais. Nas palavras de Azanha, "não há garantia nenhuma de que esse progresso pessoal" do professor "seja variável relevante para a melhoria do ensino na situação concreta de uma dada escola". Daí a conclusão de que "a questão da qualidade do ensino é, pois, uma questão institucional" e "a entidade a ser melhorada é a escola e não o professor" (1995, p. 204). Por esse motivo, as recomendações de Azanha a respeito da formação de professores, sobretudo em seus últimos escritos (2006), tinham como referência as noções de escola e de vida escolar. "Novas propostas de formação docente", dizia ele, "devem partir do próprio conceito de escola" (2006, p.64); a "vida escolar", em sua opinião, deveria constituir “o centro das preocupações teóricas e das atividades práticas em cursos de formação de professores" (2006, p. 63).

Até o momento apenas insinuamos as relações entre a autonomia da escola e a noção de vida escolar na obra de Azanha. Esses indícios despontaram aqui e ali nas entrelinhas de nossa discussão das críticas à ideia de formação do professor abstraído da cultura institucional de uma escola. Dissemos que a vida de cada escola é uma comunidade histórica com vizinha e endereço únicos. Essa afirmação corresponde à constatação de Azanha, registrada no primeiro capítulo, de que cada escola possui uma realidade pedagógico-social própria, desenvolvida "à medida que passa o tempo e que se consolidam as relações com a comunidade" (1995, p. 204). Dissemos também que a melhoria da qualidade do ensino oferecido pela escola pública democratizada é inviável por meio da melhoria do desempenho abstrato dos professores em particular. Para Azanha, a melhoria do ensino não depende da atualização pessoal do professor em novas tecnologias educacionais mas sim da alteração de práticas institucionais da escola. Vejamos finalmente como esses dois pressupostos - o reconhecimento do caráter singular de cada escola e a natureza institucional dos problemas da escola democratizada - articulam-se na proposta da autonomia educativa como referência para a melhoria do ensino público. 


\subsection{Da vida escolar à autonomia da escola}

No segundo capítulo deste trabalho, chamamos a atenção para as coordenadas conceituais traçadas por Azanha a fim de discernir a novidade representada pela vida escolar da escola democratizada. Vimos que as diferenças significativas da nova instituição eram exibidas por meio da relativização dos pressupostos e critérios correlatos à vida do antigo ginásio seletivo usados na descrição e avaliação da nova realidade educacional. Desse modo, a noção de qualidade de ensino baseada no rendimento da escola em termos de aprovados e retidos e a ideia da escola como um preceptorado coletivo foram datadas como expressivas de uma forma ginasial de compreensão da vida escolar não generalizável para outras circunstâncias educativas.

Ao apontar a relatividade desses critérios, entretanto, Azanha não presume que outros problemas possam ser atribuídos à escola democratizada a partir de outros critérios de descrição. O ponto importante é que a avaliação de seus alegados problemas deve levar em consideração a novidade da instituição. O próprio Azanha, na verdade, faz referência aos problemas e à "crise" da escola democratizada em algumas oportunidades (1987, p. 124; 1995, pp. 11-12; pp.112-113; 2006, p. 62). Curiosamente, porém, o autor não oferece nessas alusões um quadro detalhado da crise da escola nem indica explicitamente os critérios que o levam a detectar deficiências do ensino público em geral ${ }^{46}$. Por esse motivo, aliás, evitamos neste trabalho a tentação de estabelecer qualquer definição geral do que seria um problema de ensino para Azanha. As ressalvas do autor às avaliações banalizadas da escola já constituem referência para identificar o que não pode ser critério de qualidade do ensino público democratizado.

A vagueza de Azanha nessa questão, longe de constituir uma falha, é coerente com suas ideias a respeito do encaminhamento das alegadas dificuldades das escolas. Em primeiro lugar, a possibilidade de inventariar os problemas gerais do ensino público pressupõe o conhecimento das práticas e rotinas cotidianas das escolas. Como vimos, esse conhecimento não era disponível nem mesmo àqueles especialistas empenhados em melhorar a prática docente nos cursos de aperfeiçoamento do magistério. Esse, entretanto,

\footnotetext{
46 Talvez a única ocasião em que Azanha apresente uma avaliação geral da qualidade do ensino público ocorra no seguinte trecho, a respeito da escola básica no estado de São Paulo: “[...] na última década do século [década de 1990], a escola paulista de $1^{\circ}$ grau ainda não abrange toda a população escolarizável e mesmo aquela parcela que é alcançada acaba, em proporções significativas, sendo expulsa pela evasão e pela repetência. E mesmo aqueles que sobrevivem a essa dizimação pedagógica terminam o seu curso pouco além do limiar do analfabetismo ou, pelo menos, em estado indiscutível de penúria cultural.” (AZANHA, 1995, pp. 111-112)
} 
não é o ponto mais importante. A definição dos problemas da escola pública democratizada em geral seria, na verdade, uma operação intelectual abstrata contrária ao estilo de investigação de Azanha. Embora reconheça a existência de problemas próprios da rede de escolas ou de um sistema de escolas, o autor entendia que as deficiências do ensino variavam de escola a escola. De acordo com a observação já transcrita no primeiro capítulo, “cada escola tem características pedagógico-sociais irredutíveis quando se trata de buscar soluções para os problemas que vive". Assim, a "realidade de cada escola" é "o único ponto de partida para um real e adequado esforço de melhoria" (1987, p. 124, grifos do autor).

Por mais variáveis que fossem, as dificuldades encontradas nas vidas escolares certamente não seriam diagnosticadas e resolvidas exclusivamente por meios tecnológicos. Se há uma característica indiscutível da crise da escola democratizada para Azanha é que se trata de uma questão institucional e pública. Se pudéssemos parafrasear - e até certo ponto distorcer - os comentários de Arendt sobre a crise na educação norte-americana em meados do século XX, diríamos que, como lá, a crise da escola democratizada não tem a ver simplesmente com o fato de que "Joãozinho não sabe ler", isto é, não tem a ver apenas com problemas atinentes aos métodos e procedimentos tecnológicos do professor que ensina e às competências e demais características do aluno que aprende (ARENDT, 2007, p. 222). Nos termos de Azanha, "a questão da melhoria do ensino diz respeito ao âmbito da escola, mas também ao espaço público em que ela se encontra", de modo que suas "dificuldades são antes institucionais que de cada professor" (1995, p. 23; 2006, p.100). É esse fato importante que passava ao largo das estratégias tecnocráticas de melhoria do ensino por meio da formação continuada do professorado em novas metodologias abstratas de ensino.

Tentemos deixar mais claro o caráter institucional e público dos problemas da escola democratizada. Nessa formulação, evidentemente, Azanha opõe a natureza institucional das alegadas dificuldades da escola aos diagnósticos tecnocráticos que "julgam que a melhoria do ensino depende estritamente de uma modernização de tecnologias de ensino" (1995, p. 25). Esse afã tecnocrático, no fundo, dificultava a percepção das alegadas dificuldades da escola como indícios de alterações institucionais mais amplas, para as quais não havia respostas técnicas dadas. Em outras palavras, a natureza institucional das dificuldades da escola democratizada tem a ver com os impasses próprios de uma instituição inédita: a escola básica acessível à maioria da população. E embora essas dificuldades possam exigir a adoção de novos métodos e tecnologias educacionais, as possíveis respostas a essa nova situação não se esgotam nessas medidas de cunho técnico. O que está em jogo nesse caso é a mudança 
do significado da escolarização básica e os impasses institucionais daí decorrentes. Vejamos, a esse respeito, alguns trechos retirados de diferentes escritos de Azanha.

Tanto no que diz respeito à escola como no que se relaciona coa família houve mudanças e rupturas institucionais. Descrever esse quadro como sendo de crise é uma apreciação valorativa que pode ser um descaminho [...] A emergência de novidades não é necessariamente uma indicação de crises institucionais, mas talvez apenas de mudanças sociais inerentes aos quadros da sociedade contemporânea. No caso da escola, haveria crise se o mundo escolar, que tem uma subcultura própria, permanecesse imobilizado num momento que é caracterizado por fortes mudanças sociais e culturais. [...] A escola básica de hoje não é, pois, um retrocesso com relação à escola de ontem. É uma outra escola, principalmente por ser altamente expandida, e suas alegadas deficiências precisam ser enfrentadas por um esforço permanente de investigação e busca. (AZANHA, 2006, pp. 62-63, grifos nossos)

Essa expansão [da escola básica] inviabilizou não apenas modos de atuação pedagógica como também normas de organização, administração e supervisão dos sistemas de ensino nos nível federal, estadual e municipal, Tudo tem que ser rediscutido e, com relação à ordenação e gestão dos sistemas de ensino, nenhuma norma legal já existente sobre o assunto pode ser invocada como fundamento para obstar as reordenações necessárias no presente momento. (AZANHA, 1995, p. 185 , grifos nossos)

[...] a escola pública é uma instituição social muito específica com uma tarefa de ensino eminentemente social que, por isso mesmo, exigiria um esforço coletivo para enfrentar com êxito suas dificuldades, porque essas dificuldades são antes institucionais que de cada professor. [Muitos professores, no entanto,] resistem à ideia de que os próprios objetivos escolares são socioculturais e que até mesmo o êxito do ensino de uma disciplina isolada deve ser aferido em termos da função social da escola.[...] [O professor] é membro de uma comunidade escolar com objetivos e um alcance social que vão além do ensino de qualquer disciplina. (AZANHA, 2006, p. 100, grifos nossos)

Como se vê, os comentários do autor, além de escritos em épocas diferentes, referemse a assuntos muito distintos: a formação de professores, o papel dos conselhos de educação e a noção de proposta pedagógica. Não pretendemos cometer o despropósito de reduzir as diversas afirmações de Azanha nesses comentários a um suposto argumento comum. No entanto, não podemos deixar de notar que esses comentários sugerem, de maneira semelhante, a tendência do autor em considerar as alegadas dificuldades das escolas como indicativas de impasses institucionais deflagrados pelo ineditismo da situação educacional. No primeiro trecho, a ênfase do autor não dá margens a dúvidas: a nova instituição apresenta desafios que exigem “investigação e busca”. Já no último excerto, os eventuais problemas particulares encontrados pelos professores em suas rotinas cotidianas de ensino são 
redimensionados como desafios da instituição em seu novo compromisso - eminentemente social - de garantir a escolarização básica a todos.

Nessas condições, os problemas encontrados no dia-a-dia das escolas deviam ser tratados como problemas institucionais, para os quais as respostas técnicas, como a atualização individual do professor, eram insuficientes. Nesse quadro, a única certeza de Azanha era a necessidade de adesão da escola ao princípio democrático de acesso e permanência de todos à escola. No mais, a nova situação exigia esforços institucionais da comunidade escolar para identificar e resolver seus problemas específicos. É nesse sentido que podemos considerar o uso programático de "autonomia da escola" por Azanha como uma resposta à crise do padrão de ensino ginasial. O exercício da autonomia educativa nada mais é que uma aposta de Azanha na capacidade de cada escola de diagnosticar e intervir nos problemas próprios de sua nova vida escolar de acordo com um esforço institucional e coletivo. E nessa tarefa, evidentemente, nenhuma tecnologia educacional abstrata poderia prestar socorro.

De fato, desde os primeiros escritos sobre o assunto, como o já citado Documento preliminar (1987), Azanha oferece definições muito simples do que seria o exercício da autonomia pela escola. Trata-se simplesmente de uma forma institucional de lidar com os problemas próprios da vida escolar, isto é, relativos ao conjunto de práticas, rotinas e valores próprios da instituição educativa em seu contexto local. Comparemos, a título de ilustração, duas considerações de Azanha formuladas em momentos distintos:

A autonomia da escola só ganha relevância se significar autonomia da tarefa educativa;[...] Esta só se obtém a partir de uma consciência aguda e crítica das possibilidades de atuação da escola em face da clientela e da comunidade a que serve e do esforço continuado e conjunto para ir até o limite dessas possibilidades. Enfim, a autonomia da escola é algo que se põe com relação à liberdade de formular e executar um projeto educativo.[...] Nesses termos, o projeto educativo de uma escola é o propósito de transformar a escola (e a comunidade) tomando em consideração não as prescrições de uma pedagogia abstrata, mas as condições reais de vida dos educandos. [...] Para além do alcance de todos os constrangimentos políticos, econômicos, sociais, culturais e pedagógicos, há um espaço de encontro e convívio que é potencialmente educativo. (AZANHA, 1987, pp. 144-145, grifos nossos)

Autonomia da escola para quê? [...]Só a escola, com seu diretor, seu corpo docente, seus funcionários, suas associações de pais tem que examinar sua própria realidade específica e local; fazer um balanço das suas dificuldades e se organizar para vencê-las. Não há plano de melhoria empacotado por qualquer outro órgão que possa realmente alterar, substantivamente, a realidade de cada escola. Se a própria escola não for capaz de se debruçar sobre os seus problemas, de fazer aflorar esses problemas e de se organizar para resolvê-los, ninguém fará isso por ela. [...] Qualquer plano de melhoria da escola tem de ser um plano da 
própria escola. Há escolas que conseguem organizar seu próprio plano de ensino, seu plano de melhoria que, às vezes, passa por providências não pedagógicas, mas puramente materiais e físicas. Todos nós, professores e diretores, sabemos que a escola é uma comunidade com problemas específicos, com problemas próprios. (AZANHA, 1995, pp. 24-26, grifos nossos).

Embora escritos em períodos diferentes, ambos os textos, assim como o Documento preliminar (1987) discutido no primeiro capítulo, apresentam a convicção de que apenas as escolas podem reconhecer e resolver os problemas específicos de sua vida escolar. Sem ignorar os problemas de origem extra-escolar, Azanha não deixa de atribuir à escola a tarefa de explorar as possibilidades do esforço institucional para ocupar, com um projeto de melhoria próprio, o espaço potencialmente educativo existente além de todos os constrangimentos de ordem social, política, econômica, etc. Como cada escola possui uma vida escolar singular, com deficiências igualmente particulares, Azanha não espera que um plano de melhoria padronizado, elaborado pela administração educacional, seja efetivamente útil na resolução dos problemas próprios de cada instituição.

A dimensão institucional do esforço de melhoria da escola é representada, em ambos os excertos, pela exigência de um projeto educativo ou um plano de melhoria comum a todos os profissionais da escola e eventualmente a todos os membros da comunidade escolar. Depois da aprovação da Lei de Diretrizes e Bases da Educação Nacional de 1996, Azanha passa a vincular o exercício da autonomia da escola à tarefa de elaboração e execução de um "projeto pedagógico" ou "proposta pedagógica" prevista no dispositivo legal ${ }^{47}$. Assim, a ideia de formulação de um projeto institucional próprio, já anunciada em escritos anteriores, ganha respaldo numa abertura legal considerada crucial para o autor. Essa avaliação, no fundo, reconhece na lei e nas práticas que ela potencialmente poderia induzir uma oportunidade de considerar os problemas das escolas como problemas institucionais que exigiam um empenho comum na sua identificação e resolução.

A prioridade atribuída por Azanha à exigência de uma proposta educativa comum ou de uma "proposta pedagógica" própria da escola, para usar os termos da LDB, o levou a criticar as propostas de autonomia da escola que superestimavam a importância de

\footnotetext{
${ }^{47}$ A elaboração e execução de uma proposta pedagógica pelos estabelecimentos de ensino é prevista nos artigos 12, 13 e 14 da Lei de Diretrizes e Bases da Educação Nacional de 1996. Em particular, Azanha referia-se ao inciso I do art. 12, que atribuía ao estabelecimento de ensino a tarefa de "elaborar e executar sua proposta pedagógica"; ao inciso I do art. 13 e 14, que incumbiam os docentes e demais profissionais da educação a participar da "elaboração da proposta pedagógica" da escola. Ver LEI DE DIRETRIZES E BASES DA $\begin{array}{llllll}\text { EDUCAÇÂO NACIONAL (Lei. } & \text { 9394/96). } & \text { Disponível } & \text { em }\end{array}$ http://www.planalto.gov.br/ccivil_03/Leis/L9394.htm. Acessado em 10/02/2016
} 
determinadas condições administrativas ou burocratizavam a noção de proposta ou projeto pedagógico. A primeira tendência é criticada pelo autor por identificar a autonomia da escola a um certo arranjo administrativo da unidade escolar caracterizado, entre outras coisas, pela vigência de um regimento próprio e pelo funcionamento de um conselho de escola e de uma associação de pais e mestres. Sem menosprezar a importância desses institutos organizacionais, Azanha lembrava no entanto que a autonomia da escola "não deve nem pode se esgotar nisso" (AZANHA, 1987, p. 143). Embora essas condições institucionais viabilizem a autonomia da escola, essa expressão, para Azanha, dizia respeito antes de mais nada à formulação, pela escola, de uma proposta educativa própria.

A burocratização da autonomia é atribuída por Azanha àqueles que viam a proposta pedagógica como "mais uma inútil exigência burocrática de papelada a ser preenchida" (AZANHA, 2006, p. 95). Nesse caso, a oportunidade valiosa oferecida pela LDB de 1996 seria rebaixada a uma exigência legal marcada por "normas, prazos e especificações" estabelecidos pela administração educacional. Esse risco de burocratização da autonomia da escola tinha seu complemento no risco de burocratização dos aspectos pedagógicos da autonomia. Assim, a imposição de que cada escola entregasse à Secretaria de Educação uma proposta pedagógica poderia levar à criação da "ciência dos projetos ou roteiros burocratizados" para auxiliar a instituição a cumprir a determinação legal de autonomia (AZANHA, 2006, p. 104)

À parte a ironia dessa última situação, as ideia de Azanha a respeito da proposta pedagógica eram extremamente simples. Em sua formulação talvez mais acabada, presente num texto exatamente sobre Proposta pedagógica e autonomia da escola (2006), o autor assim define a oportunidade de elaboração de uma proposta pedagógica ou um projeto pedagógico pela escola prevista na LDB sancionada poucos anos antes:

\footnotetext{
O projeto pedagógico da escola é apenas uma oportunidade para que algumas coisas aconteçam e dentre elas o seguinte: tomada de consciência dos principais problemas da escola, das possibilidades de solução e definição das responsabilidades coletivas e pessoais para eliminar ou atenuar as falhas detectadas. Nada mais, porém isso é muito, e muito difícil (AZANHA, 2006, p. 96).
}

Como se vê, Azanha é bastante sumário na definição da tarefa de elaboração de uma proposta pedagógica. Avesso às complicações das "ciências dos projetos", Azanha reconhece na ideia de elaboração de uma proposta educativa uma oportunidade para que a escola estabeleça diretrizes e princípios comuns de trabalho para lidar institucionalmente 
com suas dificuldades próprias. Nessa definição, a proposta pedagógica não é só - ou não é principalmente - um documento elaborado pela escola para formalizar sua linha de trabalho. "O importante", diz Azanha, é "o empenho comum numa reflexão institucionalmente abrangente e o firme propósito de alterar práticas nos sentidos indicados por essa reflexão" (AZANHA, 2006, p. 104). A “papelada" que formaliza o projeto pedagógico pode ser relevante na medida em que materializa o delineamento alcançado pela escola em seus esforços autônomos de resolução de seus problemas. Entretanto, essa exigência burocrática não pode substituir o essencial: o empenho institucional da coletividade escolar na identificação e tratamento dos problemas de sua vida escolar própria. No fundo, a oportunidade de elaboração e execução de uma proposta ou um projeto pedagógico corresponde ao exercício da autonomia educativa pela escola.

Essa vinculação entre a ideia de proposta pedagógica e a autonomia da escola aparece de maneira elucidativa em outro comentário. Neste caso, a natureza institucional do esforço de melhoria do ensino da escola nos termos de sua realidade própria estabelece em definitivo a associação entre a vida ou o mundo escolar e a autonomia da escola:

A ideia de um projeto pedagógico, visando a melhoria desse mundo com relação
às suas práticas específicas, será uma ficção burocrática se não for fruto da
consciência e do esforço da coletividade escolar. Por isso, é ela, a escola, que
precisa ser assistida e orientada sistematicamente, e seus membros temporários, os
professores não devem ser aperfeiçoados abstratamente para o ensino de sua
disciplina, mas para a tarefa coletiva do projeto escolar. (AZANHA. 2006, p. 103)

Não deixa de ser curioso que o próprio Azanha tenha antecipado, em diferentes momentos, as dificuldades do programa veiculado pelo uso da "autonomia da escola" nesses termos. Essas dificuldades não eram pequenas e tinham natureza diferente. Por exemplo, em Obstáculos institucionais à democratização do ensino em São Paulo (1987), redigido em 1983, o autor reconhece que a atribuição da autonomia às escolas para a elaboração de um plano de melhoria próprio contava com a tenaz oposição da própria estrutura administrativa da rede de escolas herdada do regime militar e "implantada para funcionar autocraticamente" (1987, p. 138). Uma escola autônoma, nesse sentido, significaria desmontar um aparato administrativo da magnitude de uma Assessoria Técnica de Planejamento e Controle Educacional que funcionava à época com cerca de 150 técnicos educacionais, responsáveis pelas mais variadas atribuições, do planejamento educacional à assinatura de convênios da Secretaria de Educação. Com tal centralização administrativa da vida das escolas, pressupunha-se "uma escola domesticada e simples cumpridora de ordens e não uma escola 
autônoma, buscando os seus próprios caminhos de melhoria do ensino" (AZANHA, 1987, p.139). A não ser que a administração educacional revisasse sua própria estrutura clientelista e autocrática, o discurso da autonomia seria "semanticamente vazio" (1987, p. 139).

Além desses obstáculos administrativos, a defesa da autonomia da escola de Azanha era desafiada pelo realismo exacerbado do discurso tecnocrático. Favoráveis aos pacotes padronizados de melhoria do ensino, essas considerações apostavam na incapacidade da escola de melhorar o ensino segundo um projeto próprio. Como já apontava Azanha no Documento preliminar, "pode-se argumentar contra essa visão" da autonomia da escola "ponderando que ela é não-realista e que as escolas não serão capazes de perceber e superar as próprias deficiências" (AZANHA, 1987, p. 125). Ademais, nada assegurava que, uma vez identificadas as deficiências da escola e traçadas as ações para sua superação, os resultados obtidos corresponderiam às expectativas da administração educacional com relação a certas metas de desempenho. Como reconhecerá Azanha mais tarde, "eventualmente, escolas às quais se permita autonomia de decisão e de ação poderão encontrar dificuldades para atingir níveis de desempenho exteriormente fixados" (AZANHA, 1995, p. 176).

Por fim, o esforço autônomo da escola para elaboração de uma proposta pedagógica própria poderia, pelo menos por princípio, engendrar efeitos contrários à ideia de autonomia educativa. Pois, segundo Azanha, "o simples fato de que cada escola, no exercício de sua autonomia, elabore e execute o seu próprio projeto escolar não elimina o risco de supressão de divergências" e nem mesmo "a possibilidade de que existam práticas escolares continuamente frustradoras de uma autêntica educação para a democracia" (AZANHA, 2006, p. 93). Em outras palavras, a elaboração de um projeto pedagógico pode ser confundida com uma exigência incondicional de consenso de todos os agentes escolares com relação aos princípios acordados, o que poderia criar condições "para a edificação de um ambiente autoritário e opressivo resguardado por um regimento próprio" (AZANHA, 2006, p. 94).

Considerando essas sérias ressalvas, por que Azanha julgava, apesar das indicações em contrário, que a autonomia da escola seria uma resposta interessante às dificuldades da escola democratizada? Se a proposta de autonomia da escola, diferentemente do método comeniano, não prometia nem sequer êxito, o que levaria Azanha a aferrar-se na sua defesa em variados escritos? Enfim, o que levaria o autor a apostar na capacidade de cada instituição escolar de avaliar e resolver os próprios problemas de ensino, apesar da ausência de garantias 
desse programa educativo? Encaminhando-se para a conclusão do trabalho, tentaremos responder a essas indagações nas considerações que seguem. 


\section{CONSIDERAÇÕES FINAIS: \\ RESPONSABILIDADE, O PRESSUPOSTO ÉTICO DA AUTONOMIA DA ESCOLA}

Dissemos no último capítulo que nosso autor recomendava a avaliação independente dos programas educacionais sugeridos por definições e proposições científicas ou teóricas sobre o ensino, a aprendizagem, a gestão escolar ou qualquer outro aspecto da educação. Seguindo Scheffler, Azanha distinguia a avaliação da validade científica ou teórica desse tipo de enunciado da avaliação de sua legitimidade como princípio de ação pedagógica. $\mathrm{O}$ respaldo científico de uma afirmação pedagógica, nesses termos, não implica a conveniência da adoção de práticas derivativas, que devem sempre ser julgadas segundo critérios abrangentes relativos a valores. Ora, não residiria aí uma justificativa interessante para o programa veiculado pelo uso específico de autonomia da escola por Azanha? Para além de qualquer consideração da efetividade ou da eficiência da proposta, não seria a defesa da autonomia da escola uma escolha ética? Não há mais nesse programa educativo que a presunção da eficácia do esforço institucional da escola em resolver os problemas da vida escolar?

Supomos que há. De fato, a relação entre a proposta de autonomia da escola e certos valores não parece uma contingência no uso que Azanha faz do conceito em seus escritos. Ao contrário, arriscamos dizer que a responsabilidade pública dos educadores da escola é o pressuposto ético da autonomia. A não ser que a autonomia seja degenerada na ficção burocrática de preenchimento da papelada do projeto pedagógico ou identificada ao simples funcionamento formal de um Conselho de Escola, a ideia da autonomia da escola pressupõe, para Azanha, a responsabilidade da instituição pela proposta educativa que desenvolve. Nesses termos, a liberdade da escola para elaborar e executar uma proposta pedagógica própria pressupõe a responsabilidade dos educadores por suas ações. Do mesmo modo que ninguém pode ser considerado responsável por aquilo que foi forçado a fazer, uma escola que é constrangida a adotar certas práticas não pode ser integralmente responsável pelo que faz sob tais circunstâncias. Numa palavra, para Azanha, a responsabilidade é inseparável da ideia de autonomia educativa.

O pressuposto ético da autonomia da escola é destacado pelo autor desde a primeira ocorrência da expressão, no referido Documento preliminar (1987). Para justificar a proposta de concessão de autonomia às escolas na elaboração de seu próprio plano de 
melhoria do ensino, adotada nos primeiros meses da administração Montoro, Azanha afirmava num tom enfático que "a tarefa educativa tem como pressuposto ético a autonomia de quem educa". Se "sonegada esta condição", sentencia ele, "a escola perde a sua autêntica feição educativa e transforma-se em instrumento de doutrinação" (AZANHA, 1987, p.129). Sabemos que o autor não supunha que a vida escolar fosse completamente controlável por determinações da administração educacional ou que o dia-a-dia da instituição nada mais fosse que o cumprimento de exigências legais. Os comentários do capítulo anterior deixam claro que, para o autor, a vida que se passa no cotidiano das escolas corresponde a uma cultura complexa mais ou menos autônoma em relação às normas burocráticas. As rotinas escolares são muito mais permeadas por elementos desse mundo do que gostaria de reconhecer a tecnocracia. Por que, então, a condenação veemente das ordenações legais que pretendem centralizar as decisões a respeito da vida escolar? Além do propósito mobilizador do documento, a ênfase evidente de Azanha nessa questão pode ser explicada antes pela defesa incondicional do princípio da responsabilidade educativa, principal prejudicada da autocracia das administrações educacionais. A "aplastante uniformidade" das normas que pretendem "eliminar a possibilidade de erro" das escolas, no fundo, acabaria por "eliminar a responsabilidade". (AZANHA, 1987, p.129)

Talvez em razão do apreço pela responsabilidade como princípio ético da educação, Azanha em mais de uma oportunidade dirigia críticas polêmicas ao professorado do antigo ginásio, que não entenderia a dignidade ética e política da abertura repentina de vagas promovida pela reforma Ulhoa Cintra. Segundo palavras de Azanha em A estigmatização

\section{do ensino público,}

Tudo se passa como se a falência da escola pública tivesse sido decretada pela política de expansão maciça de vagas iniciada alguns anos atrás. [...] o mais intrigante é que dentre as coisas irrelevantes parece estar a própria atuação do magistério, pois, de outro modo, é incompreensível que esse próprio magistério não reconheça de forma objetiva e consequente a parcela que lhe cabe na qualidade oferecida do ensino público. (AZANHA, 1995, pp. 11-12).

Destacado do devido contexto, o fragmento pode bem sugerir certas semelhanças entre os comentários de Azanha e a tendência vigente de atribuir os resultados insatisfatórios do desempenho de alunos de escolas públicas em avaliações de larga escala à incompetência dos professores - o que tem justificado reformas administrativas que, entre outras coisas, facilitam a demissão do professor que não comprove sua eficiência na elevação dos índices em avaliações posteriores. Não é esse o caso. As críticas do autor, na verdade, dirigem-se à 
resistência do magistério em aceitar a política de democratização do ginásio. Na interpretação de Azanha, a incompreensão da escola de oito anos como expressão de um direito democrático traduzia-se na atitude reativa do magistério de manter as exigências acadêmicas do antigo ginásio seletivo e abusar da reprovação como instrumento de restauração das antigas condições educacionais. Numa avaliação retrospectiva, Azanha registra que principalmente o professor do antigo ensino secundário "não aceitou a mudança de critérios para admissão dos alunos no ginásio e estabeleceu seus próprios critérios, quase como em represália à política executada pela Administração". Assim, "não houve compreensão de que o problema" da abertura de vagas "não era meramente pedagógico", tratando-se antes de "um problema político, resolvido ao nível político, que não poderia ser corrigido e detido por medidas de caráter pedagógico, mas deveria ser complementado por elas" (AZANHA, 1987, p. 113).

Se prestarmos a devida atenção, porém, veremos que essas observações controversas, mais do que apontar culpados pelos problemas da escola, procuram reafirmar a responsabilidade inalienável dos educadores pelos rumos da instituição. Nesse sentido, não se trata de culpar o professor pelas mazelas da escola pública, mas de lembrá-lo de seu compromisso com a melhoria do ensino como membro de uma instituição inédita, detentora de uma proposta educativa que garanta o direito universal à educação básica. Preliminarmente, cabe notar que Azanha não deixa de reconhecer que a abertura de vagas ocasionou impasses para o magistério. Além dos esperados problemas relativos à ocupação do espaço nos primeiros anos, houve também, paulatinamente, a diminuição do investimento de recursos estatais correspondentes à importância da expansão de vagas (AZANHA, 1987, p. 114; 1995, p. 16). Nessas condições, o magistério deparou-se com uma situação em que “os parâmetros pedagógicos vigentes revelaram-se ineficazes para enfrentar a situação emergente". Dada a tendência das administrações educacionais de tentar resolver os problemas da escola recorrendo a novas tecnologias educacionais, "tentativas bem intencionadas de alterações técnicas do ensino acabaram malogrando" justamente "porque a transformação escolar ocorrida, pelas suas raízes político-sociais, deu origem a problemas que, não obstante escolares, tinham sua possibilidade de solução fora de coordenadas estritamente pedagógicas" (AZANHA, 1995, p. 13).

Mesmo reconhecendo os impasses enfrentados pelo magistério, Azanha não admitia, entretanto, sua indiferença com relação ao encaminhamento dos desafios da nova realidade escolar, dissimulada frequentemente na atribuição de todos os problemas da escola a 
questões estruturais e corporativas, tais como os parcos investimentos estatais e as condições de remuneração e carreira. Ainda que reconheça a legitimidade dessas reivindicações, Azanha censurava o magistério por descolá-las de seu compromisso institucional com a melhoria do ensino público. De acordo com o autor, "o magistério" desligou "suas reivindicações salariais da exigência de um melhor ensino público", de modo que, a partir de tal divórcio, "a escola pública perde o apoio daqueles que deveriam ser seus defensores naturais". Nesse cenário, “deixada à sua própria sorte e estigmatizada, a escola pública exatamente por ser pública - parece destinada por sua própria natureza a ser uma instituição ineficiente e irrecuperável" (AZANHA, 1995, pp. 16-17). O ponto fundamental, portanto, não é a suposta constatação de que a escola pública apresente um ensino irrecuperável devido às deficiências do magistério. O essencial nas observações de Azanha é sua patente contrariedade diante das estratégias de abstração da responsabilidade dos educadores para lidar com os problemas eventualmente verificados na escola. O que o autor exigia do magistério era seu compromisso institucional com a resolução dos problemas da escola, ainda que sua origem lhe fosse alheia. Daí sua declaração:

As práticas da vida escolar estão ligadas a uma mentalidade vigente. Por isso, dissemos que a questão da autonomia não se esgota num conjunto de condições [organizacionais da escola]. É preciso que a busca da autonomia seja, em cada escola, uma oportunidade de revisão dos compromissos do magistério com a tarefa educativa. (AZANHA, 1995, pp. 145-146, grifos nossos)

Apesar da passagem do tempo, a responsabilização do magistério permanece como o pressuposto ético do uso programático da autonomia da escola. Nas décadas de 1990 e 2000, nas discussões sobre a ideia de proposta pedagógica, Azanha justificava a autonomia da escola na elaboração de sua proposta educativa própria em termos que ressoam os comentários do Documento Preliminar, de 1983. Curiosamente, os planos padronizados de melhoria de ensino impostos à rede de escolas pela administração educacional são rechaçados pelo autor não por sua comprovada ineficiência pedagógica. Antes de qualquer coisa, essas medidas tecnocráticas seriam discutíveis por desrespeitarem o princípio da responsabilidade educativa. Segundo Azanha,

Sem liberdade de escolha, professores e escolas são simples executores de ordens e ficam despojados de uma responsabilidade ética pelo trabalho educativo.[...]A consequência mais óbvia e indesejável de tentativas de homogeneização daquilo que é substantivamente heterogêneo é o fato de que as escolas ficam ou sentem-se desoneradas da responsabilidade pelo êxito de seu próprio trabalho, já que ele é continuamente objeto de interferências externas, pois ainda que essas 
interferências sejam bem intencionadas não levam em conta que a instituição "escola pública" é uma diversidade, e não uma unidade (AZANHA, 2006, pp. 9495)

Nessas condições, se fôssemos instados a responder finalmente às perguntas levantadas no final do último capítulo, diríamos que, apesar de suas admitidas dificuldades, o programa de "autonomia da escola" sugerido pelo uso que Azanha faz da expressão encontra justificativa não em sua maior ou menor eficácia no encaminhamento das dificuldades da escola democratizada. É evidente que, como procuramos mostrar há pouco, o autor acreditava que a concessão de liberdade às unidades escolares para lidar com os problemas específicos da vida escolar democratizada era mais promissora que a insistência anacrônica na introdução de novas tecnologias educacionais abstratas. Não obstante, o programa de autonomia da escola, ainda que incerto do ponto de vista de seus resultados, era sobretudo um encaminhamento digno dos problemas da escola democratizada. Digno porque, independentemente de seus desdobramentos práticos, a autonomia pressupõe o compromisso da escola com os valores públicos da responsabilidade e do pluralismo, próprios da convivência democrática. Nas formulações de Azanha,

a autonomia da escola numa sociedade que se pretenda democrática é, sobretudo, a possibilidade de ter uma compreensão própria das metas da tarefa educativa numa democracia. Sem essa possibilidade, não há como falar em ética do professor ou em ética da escola (AZANHA, 2006, pp. 93-94)

Pode ser que a autonomia da escola seja - como disse R. King Hall - apenas uma "ficção desejável", "mas também é um objetivo da democracia - extremamente útil, altamente desejável e possivelmente essencial" (AZANHA, 1995, p. 177)

Nesses termos, o uso programático da autonomia da escola pode ser visto simplesmente como uma aposta de Azanha nas possibilidades da escola democratizada de lidar com seus problemas próprios sem recorrer, para tanto, à restauração do padrão seletivo do antigo ensino ginasial. Consequente ou não, essa resposta à crise deflagrada pela democratização da escola básica é pelo menos coerente com certos valores democráticos esposados pelo autor. No fundo, as ideias de Azanha a respeito da autonomia da escola discutidas neste trabalho procuram chamar nossa atenção para o fato de que, dentre todos os problemas que a escola pública democratizada pode apresentar, o mais grave e intolerável é sem dúvida a indiferença de seus profissionais com relação ao trabalho educativo. Diferentemente de uma fábrica - em que é suficiente que o proprietário esteja ciente dos propósitos do empreendimento, restando ao trabalhador a execução indiferente de ordens - 
o trabalho na escola democratizada exige que "todos tenham bem claro os propósitos comuns dessa instituição e se organizem em função deles" (AZANHA, 1995, p. 26). Assim, ao contrário do que supõe a tecnocracia, "a ação educativa, tanto na sua dimensão individual como coletiva, requer uma consciência clara dos objetivos educacionais e dos valores a eles ligados" (AZANHA, 1995, p.176). Ao defender a autonomia da escola na elaboração de uma proposta educativa própria, Azanha simplesmente procurava evitar o risco - sempre presente - de que o professor trabalhasse na escola como se trabalhasse em uma fábrica. 


\section{REFERÊNCIAS}

\section{Livros e artigos:}

ALAIN. Reflexões sobre a educação. São Paulo: Saraiva, 1978.

ARENDT, Hannah. A condição humana. Rio de Janeiro: Forense, 2014.

ARENDT, Hannah. Entre o passado e o futuro. São Paulo: Perspectiva, 2007.

ARENDT, Hannah. Homens em tempos sombrios. São Paulo: Companhia das Letras, 2008.

AZANHA, José Mário Pires. Educação: alguns escritos. São Paulo: Editora Companhia Nacional, 1987.

AZANHA, José Mário Pires. Educação: temas polêmicos. São Paulo: Martins Fontes, 1995.

AZANHA, José Mário Pires. Escola de oito anos (a incompreensão pedagógica) in CATANI, Denice et ali (org.), Universidade, escola e formação de professores. São Paulo: Brasiliense, 1987.

AZANHA, José Mário Pires. Experimentação educacional: uma contribuição para sua análise. São Paulo, EDART, 1975.

AZANHA, José Mário Pires. A formação do professor e outros escritos. São Paulo: Ed. SENAC, 2006.

AZANHA, José Mário Pires. Uma ideia de pesquisa educacional. São Paulo: EDUSP, 2011.

BERGER, L.; LUCKMANN, T. A construção social da realidade. Petrópolis: Vozes, 1976.

BACON, Francis. Bacon (Novum Organum e Nova Atlântida). Coleção Os pensadores. São Paulo: Editora Abril, 1973.

BOTO, Carlota. Trilhas de um mestre: o legado político e pedagógico de José Mário Pires Azanha. Revista USP. São Paulo.nº 93, p. 211-224, março/abril/maio de 2012.

CARVALHO. José Sérgio Fonseca de. Construtivismo: uma pedagogia esquecida da escola. Porto alegre: Artmed, 2001. 
CARVALHO, José Sérgio Fonseca de. José Mário Pires Azanha. Coleção Educadores. Recife: Fundação Joaquim Nabuco, Editora Massangana, 2010.

CARVALHO, José Sérgio Fonseca de. Reflexões sobre educação, formação e esfera pública. Porto Alegre: Penso, 2013.

CASTELLAR, Sônia. Educação geográfica: a psicogenética e o conhecimento escolar. Caderno Cedes, vol. 25, nº6, Campinas, maio/agosto de 2006.

CHIOZZINI, Daniel Ferraz. Memória e história da inovação educacional no Brasil: o caso dos Ginásios Vocacionais (1961-1969). Tese (Doutorado em Educação) - Universidade Estadual de Campinas, São Paulo, 2010.

COLLINGWOOD, Robin George. On presupposing in An essay on metaphysics. Oxford: Oxford University Press, 1948.

COMENIUS, Johann Amos. Didática Magna. São Paulo: Martins Fontes, 2011.

CURY, Ariam José Ferreira de Castilho. Azanha e a democratização do acesso ao ensino: 1967-1970. Dissertação (Mestrado em Educação) - Faculdade de Educação da Universidade de São Paulo, São Paulo, 2012.

FERREIRO, Emília. Psicogênese da língua escrita. Porto Alegre: Artmed, 1999

GEERTZ, Clifford. Uma descrição densa: por uma teoria interpretativa da cultura in A interpretação das culturas. Rio de janeiro: LTC, 2012.

GORDO, Nívia. História da Escola de Aplicação da FEUSP (1976-1986): a contribuição de José Mário Pires Azanha para a cultura escolar. Tese (Doutorado em Educação) Faculdade de Educação da Universidade de São Paulo, São Paulo, 2010.

GUSDORF, Georges. Professores para quê? Para uma pedagogia da pedagogia. São Paulo: Martins Fontes, 2003

HANSON, N. R. Observação e interpretação. In Filosofia da Ciência. Org. Morgenbesser, São Paulo, s/d.

LIMA, Raymundo de. Educação no Brasil: o pensamento e a atuação de José Mário Pires Azanha. Tese (Doutorado em Educação) - Faculdade de Educação da Universidade de São Paulo, São Paulo, 2005.

LOVEJOY, Arthur. A grande cadeia do ser. São Paulo: Editora Palindromo, 2005.

MASSCHELEIN, Jan; SIMONS, Maarten. Em defesa da escola: uma questão pública. Belo Horizonte: Autêntica, 2013. 
MASSCHELEIN, Jan; SIMONS, Maarten. A pedagogia, a democracia, a escola. Belo Horizonte: Autêntica, 2014.

MORENO, Arley Ramos. Wittgenstein: através das imagens. Campinas: Ed. Unicamp, 1995.

NAGLE, Jorge. Educação e Sociedade na Primeira República. Rio de Janeiro: Fundação Nacional do Material Escolar, 1974.

OAKESHOTT, Michael. Learning and teaching. In PETERS, R.S. (org.).The concept of education, Routledge, 2010.

PAULINO, Clóvis Edmar. José Mário Pires Azanha: uma introdução a um pensamento de significativa contribuição ao debate educacional brasileiro (políticas públicas e práticas escolares). Dissertação (Mestrado em Educação) - Faculdade de Educação da Universidade de São Paulo, São Paulo, 2010.

PATTO, Maria Helena Souza. Formação de professores: o lugar da humanidades. In: BARBOSA, Raquel Lazzari Leite. Trajetórias e perspectivas da formação de educadores. São Paulo: Editora UNESP, 2004, p. 61-78.

PEDROSO, Leda Aparecida. Democracia, política e administração educacional. Dissertação (Mestrado em Educação) - Universidade Estadual de Campinas, São Paulo, 1991.

PENNAC, Daniel. Diário de escola. Rio de Janeiro: Rocco, 2008.

PETERS, R. S. (org.). The concept of education. Londres: Routledge, 2010.

RANCIÈRE, Jacques. O mestre ignorante: cinco lições sobre a emancipação intelectual. Belo Horizonte: Autêntica, 2010.

RYLE. Gilbert. Dilemas. São Paulo: Martins Fontes, 1993.

RYLE. Gilbert. The concept of mind. New York: Routledge, 2009.

RYLE, Gilbert. Teaching and training in PETERS, R. S. The concept of education. Londres: Routledge, 2010.

RYLE, Gilbert. The thinking of thoughts - What is Le Penseur doing? Collected Essays, Londres, Hutchinson, 1971.

SINGER, Helena. República das crianças: sobre experiências escolares de resistência. Campinas: Mercado das letras, 2010. 
SCHEFFLER, Israel. A Linguagem da Educação. São Paulo: Saraiva/EDUSP, 1974.

WITTGENSTEIN, Ludwig. O livro azul. Lisboa: Edições 70, 2008.

WITTGENSTEIN, Ludwig. Investigações filosóficas. Coleção Os pensadores. São Paulo: Editora abril, 1999.

Site:

ACERVO AZANHA. Disponível em

http://www3.fe.usp.br/secoes/inst/novo/acervo_jmpa/principal.asp. Acesso em: 13/02/16. 